ORNLTM-13483

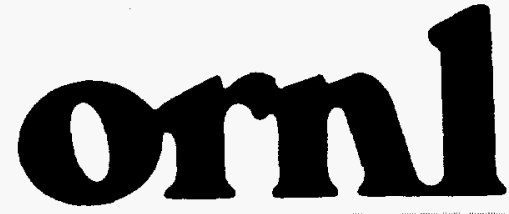

OAK RIDGE

NATIONAL

LABORATORY

WOGHAEED TALTIT

\title{
SRS MOX Fuel Lead Assemblies Data Report for the Surplus Plutonium Disposition Environmental Impact Statement
}

Fissile Materials Disposition Program

\section{REGEIVED \\ SEP 29 \\ 0811}

MAYAGEO AND OPERATEO BY

LOCKHEED WARTN ENERGY RESEARCH CORPORATION FOR THE UUTED STATES

OEPARTMENT OF ENERTY 
This report has been reproduced directly from the best available copy.

Available to DOE and DOE contractors from the Office of Scientific and Technical information, P.O. Box 62, Oak Ridge, TN 37831; prices available from (423) 576-8401.

Available to the public from the National Technical Information Service, U.S. Department of Commerce, 5285 Port Royal Rd., Springfield, VA 22161.

This report was prepared as an account of work sponsored by an agency of the United States Government. Neither the United States Government nor any agency thereof, nor any of their employees, makes any warranty, express or implied, or assumes any legal liability or responsibility for the accuracy, completeness, or usefuiness of any information, apparatus, product, or process disclosed, or represents that its use would not infringe privately owned rights. Reference herein to any specific commercial product, process, or service by trade name, trademark, manufacturer, or otherwise, does not necessarily constitute or imply its endorsement, recommendation, or favoring by the United States Government or any agency thereof. The views and opinions of authors expressed herein do not necessarily state or reflect those of the United States Government or any agency thereof. 


\section{DISCLAIMER}

This report was prepared as an account of work sponsored by an agency of the United States Government. Neither the United States Government nor any agency thereof, nor any of their employees, make any warranty, express or implied, or assumes any legal liability or responsibility for the accuracy, completeness, or usefulness of any information, apparatus, product, or process disclosed, or represents that its use would not infringe privately owned rights. Reference herein to any specific commercial product, process, or service by trade name, trademark, manufacturer, or otherwise does not necessarily constitute or imply its endorsement, recommendation, or favoring by the United States Government or any agency thereof. The views and opinions of authors expressed herein do not necessarily state or reflect those of the United States Government or any agency thereof. 


\section{DISCLAIMER}

Portions of this document may be illegible in electronic image products. Images are produced from the best available original document. 


\author{
Engineering Technology Division
}

\title{
SRS MOX FUEL LEAD ASSEMBLIES DATA REPORT FOR THE SURPLUS PLUTONIUM DISPOSITION ENVIRONMENTAL IMPACT STATEMENT
}

\author{
Project Manager \\ S. R. Greene \\ Lead Assembly EIS Data Project Lead and Author \\ D. G. O'Connor \\ Contributing Authors \\ ORNL \\ $\underline{\text { SRS }}$ \\ S. E. Fisher \\ R. L. Geddes \\ R. Holdaway \\ A. P. Poon \\ S. B. Ludwig \\ D. L. Spiker \\ R. N. Morris \\ R. R. Rahn \\ J. Sease \\ V.S. White \\ K. L. McElhaney \\ J. J. Carbajo
}

Date Published: August 1998

\author{
Prepared by \\ OAK RIDGE NATIONAL LABORATORY \\ Oak Ridge, Tennessee 37831 \\ managed by \\ LOCKHEED MARTIN ENERGY RESEARCH CORP. \\ for the \\ U.S. DEPARTMENT OF ENERGY \\ under contract DE-AC05-96OR22464
}





\section{CONTENTS}

LIST OF FIGURES

LIST OF TABLES.

ACRONYMS

ABSTRACT.

1. INTRODUCTION AND SCHEDULE

2. SITE MAP AND THE LA FACILITY DESCRIPTION

2.1 SITE LOCATION

2.1.1. Site Description.

2.1.2 Summary of MOX Site Evaluation

2.1.3 Summary of Alternative Investigations

2.1.4 Facilities Data

2.2 ASSUMPTIONS.

2.3 CATEGORY I RECOMMENDED MOX OPTION

2.3.1 Description of Project Work

2.3.2 MOX Facilities.

2.3.3 Unique Features of the MOX Facility

2.4 NON-CATEGORY I ALTERNATE MOX DEMONSTRATION OPTION

2.4.1 General Discussion

2.4.2 Blending Process Description

2.4.3 MOX Demonstration Fuel Processing Description

2.4.4 Bundle Assembly and Storage Description

2.4.5 Non-Category I Project Work Description.

3. PROCESS DESCRIPTIONS

3.1 PROCESS FLOW DIAGRAM..

3.2 WASTE MANAGEMENT FLOW DIAGRAMS ……..................................................... 19

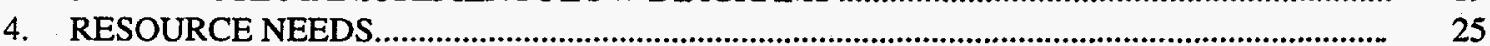

4.1 CONSTRUCTION RESOURCE NEEDS.................................................................... 25

4.1.1 Annual Utility Consumption ................................................................................... 25

4.1.2 Chemicals ............................................................................................................... 25

4.1.3 Materials and Resources Consumed ..................................................................... 25

4.2 OPERATIONAL RESOURCE NEEDS ……….................................................................. 25

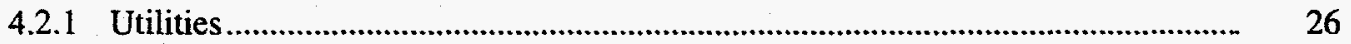

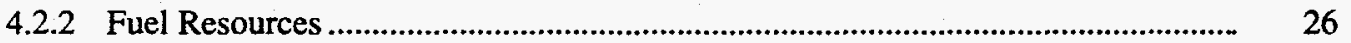

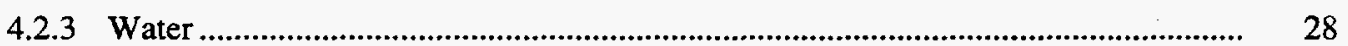

4.2.4 Process and Nonprocess Chemicals and Compounds ............................................. 28

4.2.5 Radioactive Process Materials .............................................................................. $\quad 30$

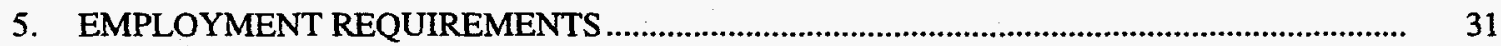

5.1 ANNUAL EMPLOYMENT REQUIREMENTS DURING OPERATION

OF THE LA FABRICATION FACILITY

5.2 RADIATION DOSES (WHOLE BODY) TO INVOLVED WORKERS DURING MODIFICATION OF THE LA FABRICATION FACILITY ............................ $\quad 32$

5.2.1 Employment During Construction of the Category I Approach .............................. 32

5.2.2 Employment During Construction of the Non-Category I Approach ........................ 33

5.3 RADIATION DOSES (WHOLE BODY) TO INVOLVED WORKERS DURING OPERATION OF THE LA FABRICATION FACILITY.................................. $\quad 33$

6. WASTES, EMISSIONS, AND EXPOSURES ......................................................................... 35

6.1 WASTES GENERATED DURING FACILITY MODIFICATION ................................... 35

6.1.1 Emissions During Construction ............................................................................. 36

6.1.2 Effluents During Construction .............................................................................. 36 
6.1.3 Radiological Impact During Construction ............................................................. 36

6.1.4 Radiological Impact to Employees.................................................................. 36

6.1.5 Radiological Impact to the Public............................................................................ 37

6.2 WASTES GENERATED DURING OPERATION OF THE FACILITY .......................... 37

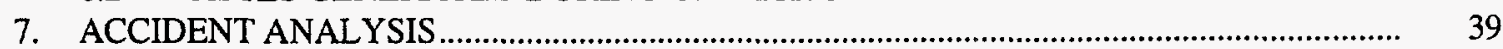

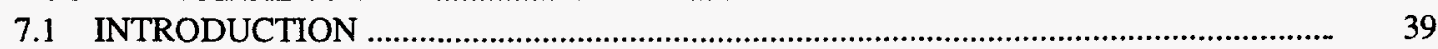

7.2 GENERAL APPROACH AND GENERIC DESIGN ASSUMPTIONS ............................ 39

7.2.1 Accident Analysis Approach ............................................................................ 39

7.2.2 Facility Design Assumptions ............................................................................ 40

7.3 SELECTED EVENTS FOR THE LA EIS ANALYSIS....................................................... 43

7.3.1 Criticality Event................................................................................................. 43

7.3.2 Evaluation Basis Seismic Event ......................................................................... 45

7.3.3 Evaluation Basis Fire Event ............................................................................... 45

7.3.4 Evaluation Basis Explosion Event....................................................................... 47

7.3.5 Beyond-Evaluation Basis Seismic Event ............................................................... 50

7.3.6 Beyond-Evaluation Basis Major Building Fire ...................................................... 52

7.4 EVALUATION OF POTENTIAL CHEMICAL SOURCE TERMS................................... 52

7.5 SITE SPECIFICS FOR THE SRS BUILDINGS …...................................................... 54

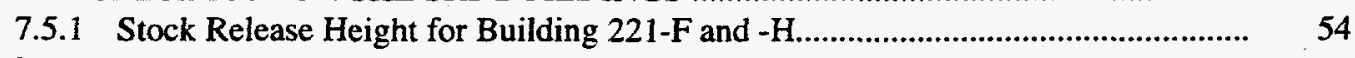

7.5.2 Evaluated Seismic Attributes for Building 221-F and $-\mathrm{H}$.................................... $\quad 55$

7.5.3 Stock Release Height for Building 773-A ........................................................... 55

7.5.4 Evaluated Seismic Attributes for Building 773-A................................................. 55

8. TRANSPORTATION ........................................................................................................ 57

8.1 OPERATIONS-RELATED TRANSPORTATION REQUIREMENTS ............................ 57

8.1.1 Feed Materials .............................................................................................. 57

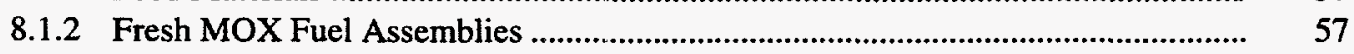

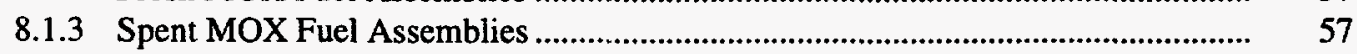

9. QUALITATIVE DECONTAMINATION AND DECOMMISSIONING DISCUSSION ........... 63

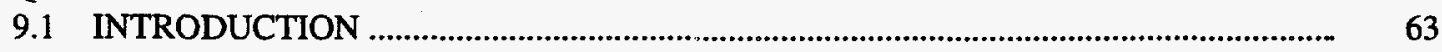

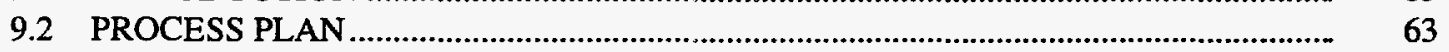

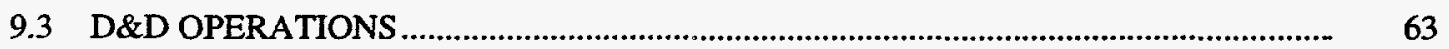

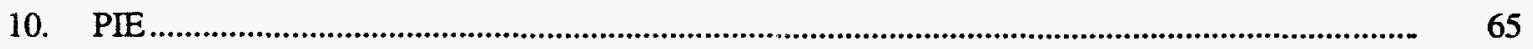

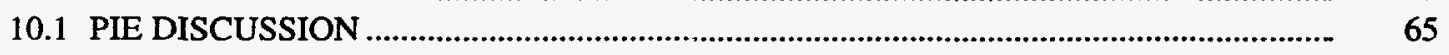

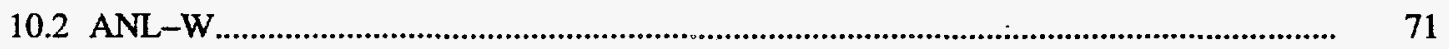

10.2.1 Main Cell ................................................................................................. 72

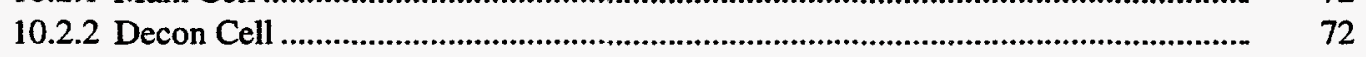

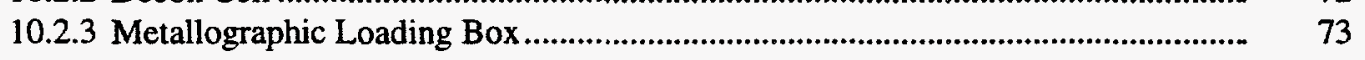

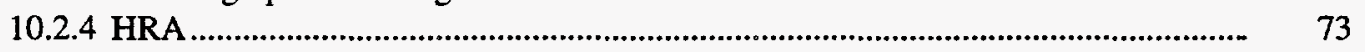

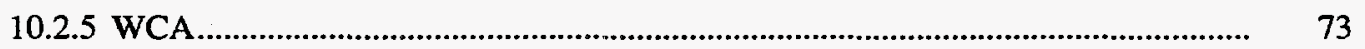

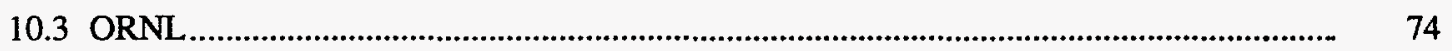

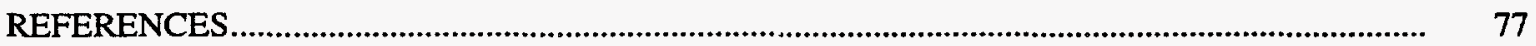

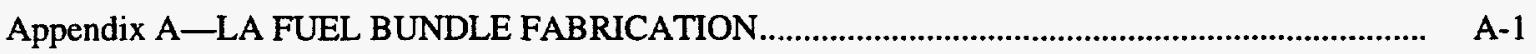

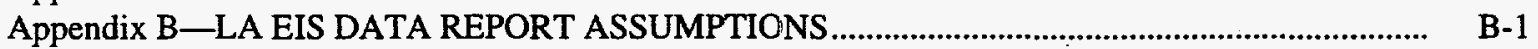

SRS RESPONSE TO THE SUPPLEMENTAL LEAD TEST ASSEMBLY EIS DATA CALL .......... S S-1 


\section{LIST OF FIGURES}

Figure

Page

Simplified LA process diagram ...........................................................................................

LA program schedule ................................................................................................. 5

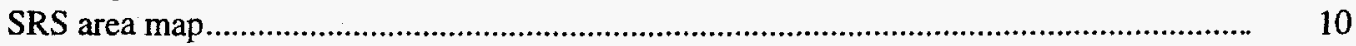

Category I MOX facility proposed site ………….............................................................. 11

Non-Category I alternative powder preparation location ..................................................... 12

Non-Category I facility alternative pellet fabrication and rod fill location ............................ 13

LA MOX fuel flow sheet outline with annual throughputs................................................... 20

Waste generated during LA MOX fuel fabrication facility operation................................... 22

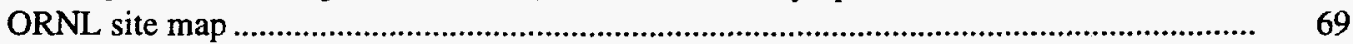

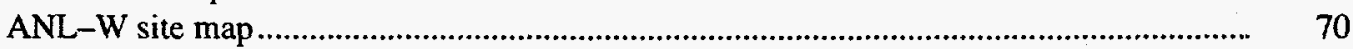

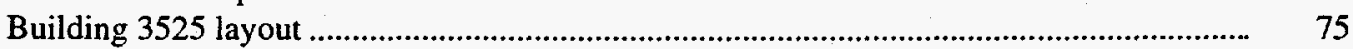

A.1 LA MOX fuel pellet flow sheet outline ......................................................................... A-3

A.2 LA MOX fuel $\mathrm{PuO}_{2}$ powder receipt and storage ............................................................ A-4

A.3 Detailed flow sheet of LA pellet fabrication.................................................................. A-5

A.4 Detailed flow sheet of $L A$ rod fabrication.................................................................... A-6

A.5 Detailed flow sheet of LA bundle assembly (LWR) ........................................................ A-7 
Page Intentionally Blank 


\section{LIST OF TABLES}

Table

LA fabrication facility schedule.

LA testing schedule

LA MOX fuel material requirements.

Assumptions made to determine LA MOX fuel material requirements .............................. 7

LA MOX fuel fabrication requirements ........................................................................... 21

Resource needs during operation of the ORNL LA fabrication facility ............................... 27

Annual employment requirements during operation of the LA fabrication facility .............. 31

Assumptions used in consideration of staffing levels for the LA fabrication facility........... 32

Estimated construction employment for the Category I approach.......................................... $\quad 32$

10 Estimated construction employment for the non-Category I approach ................................... 33

Radiation doses (whole body) to involved workers during operation of the

LA fabrication facility

Total wastes generated during construction for the Category I approach

Total wastes generated during construction for the non-Category I approach

Emissions during peak construction year

Estimated waste generated during operation of the LA fabrication facility ........................... 38

Specific activities for process powders.

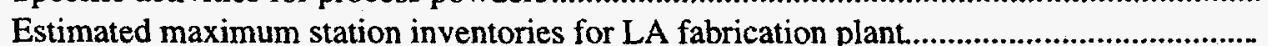

Source term for the evaluation basis criticality event

Source term for the evaluation basis seismic event

Source term for the evaluation basis fire.

Source term for the evaluation basis explosion.

Source term for beyond the evaluation basis seismic event .

Source term for beyond the evaluation basis major building fire/building collapse .

Comparison of LA facility annual usage and reportable quantity per 40 CFR 302

Transportation of $\mathrm{PuO}_{2}$ to support LA fabrication.

Transportation of depleted $\mathrm{UO}_{2}$ to support LA fabrication

Transportation of materials to support LA fabrication (LEU fuel assemblies)

Transportation of LAs to generic reactor site ...

Fresh MOX fuel isotopic content.

Transportation of irradiated LAs to the PIE site.

Spent MOX fuel isotopic content

Examples of casks for LWR spent fuel

Estimated waste generated during the LA PIE

Radiation doses to involved workers during the LA PIE

PIE estimates for EIS.

Assumptions used for the LA EIS data reports 
Page Intentionally Blank 


\section{ACRONYMS}

\begin{tabular}{|c|c|}
\hline $\mathrm{ACL}$ & administrative control level \\
\hline AEC & U.S. Atomic Energy Commission \\
\hline $\mathrm{ARF}$ & airborne release fraction \\
\hline AL & analytical laboratory \\
\hline ALARA & as low as reasonably achievable \\
\hline ANL-W & Argonne National Laboratory-West (at INEEL) \\
\hline ASTM & American Society for Testing and Materials \\
\hline BRET & Breeder Reprocessing Engineering Test \\
\hline BWR & boiling-water reactor \\
\hline CAA & Clean Air Act \\
\hline CCCTF & Core Conduction Cooldown Test Facility \\
\hline CEDE & committed effective dose equivalent \\
\hline CERCLA & Comprehensive Environmental Response, Compensation, and Liability Act of 1980 \\
\hline CFA & Central Facilities Area (ANL-W) \\
\hline CFR & Code of Federal Regulations \\
\hline $\mathrm{CH}$ & contact-handled \\
\hline CMC & confirmatory measurement counter \\
\hline CMR & Chemistry and Metallurgy Research \\
\hline CRBR & Clinch River Breeder Reactor \\
\hline CRL & Central Research Laboratory \\
\hline CS & containment and surveillance \\
\hline CST & Chemical Science and Technology \\
\hline CWA & Clean Water Act of 1972 \\
\hline $\mathrm{D} \& \mathrm{D}$ & decontamination and decommissioning \\
\hline $\mathrm{D} \& \mathrm{R}$ & dismantling and rearrangement \\
\hline dc & direct current \\
\hline DOE & U.S. Department of Energy \\
\hline DWPF & defense waste processing facility \\
\hline EA & environmental assessment \\
\hline EBR-I & Experimental Breeder Reactor-I \\
\hline EBR-II & Experimental Breeder Reactor-II \\
\hline EIS & environmental impact statement \\
\hline EJ & environmental justice \\
\hline EMM & electro-mechanical manipulators \\
\hline EPA & Environmental Protection Agency \\
\hline ER & Equipment Room \\
\hline ETB & Engineering Test Bay \\
\hline FAA & Fuel Assembly Area \\
\hline FCF & Fuel Conditioning Facility \\
\hline FCFS & Fueled Clad Fabrication System \\
\hline FEMA & Federal Emergency Management Agency \\
\hline FFTF & Fast-Flux Test Facility \\
\hline FMEF & Fuels and Materials Examination Facility \\
\hline FMDP & Fissile Materials Disposition Program \\
\hline FMF & Fuel Manufacturing Facility \\
\hline FONSI & finding of no significant impact \\
\hline FR & fire resistive \\
\hline FTE & full-time equivalent \\
\hline GT-MHR & Gas Turbine Modular High-Temperature Gas-Cooled Reactor \\
\hline HAP & hazardous air pollutant \\
\hline HEPA & high-efficiency particulate air \\
\hline
\end{tabular}




\begin{tabular}{|c|c|}
\hline HEU & highly enriched uranium \\
\hline HFEF & Hot Fuel Examination Facility \\
\hline $\mathrm{HM}$ & heavy metal \\
\hline $\mathrm{HP}$ & Health Physics \\
\hline HPFL & High Performance Fuel Laboratory \\
\hline HRA & Hot Repair Area \\
\hline HRR & Hot Repair Room \\
\hline HVAC & heating, ventilating, and air conditioning \\
\hline HWMA & Hazardous Waste Management Act of 1983 \\
\hline I\&C & Instrumentation and Controls \\
\hline IAEA & International Atomic Energy Agency \\
\hline ICPP & Idaho Chemical Processing Plant \\
\hline IDAPA & Idaho Administrative Procedures Act \\
\hline IFEL & Irradiated Fuels Examination Laboratory \\
\hline IFR & Integral Fast Reactor \\
\hline IMGA & Irradiated Microsphere Gamma Analyzer \\
\hline INEEL & Idaho National Engineering and Environmental Laboratory \\
\hline INRAD & Intrinsic Radiation Bay \\
\hline L.A & lead assembly \\
\hline L.ACEF & Los Alamos Critical Experiments Facility \\
\hline L.ANL & Los Alamos National Laboratory \\
\hline L.EU & low-enriched uranium \\
\hline L,LMW & low-level mixed waste \\
\hline LLRW & low-level radioactive waste \\
\hline LLW & low-level waste \\
\hline LLNL & Lawrence Livermore National Laboratory \\
\hline LMES & Lockheed Martin Energy Systems, Inc. \\
\hline LMITCO & Lockheed Martin Idaho Technologies Company \\
\hline LTA & lead-test assembly \\
\hline LUA & lead-use assembly \\
\hline LWR & light-water reactor \\
\hline MAA & Material Access Area \\
\hline $\mathrm{M} \& \mathrm{C}$ & Metals and Ceramics \\
\hline MC\&A & material control and accountabilizy \\
\hline MD & Office of Fissile Materials Disposition (DOE) \\
\hline MFP & multiple fission products \\
\hline MOX & mixed oxide \\
\hline MS & master/slave \\
\hline MT & metric ton \\
\hline MW & mixed waste \\
\hline NDA & nondestructive assay \\
\hline NDT & nondestructive testing \\
\hline NEPA & National Environmental Policy Act of 1969 \\
\hline NGVD & National Geodetic Vertical Datum \\
\hline NMS\&S & Nuclear Material Stabilization and Storage Division \\
\hline NMSS & Office of Nuclear Material Safety and Safeguards \\
\hline NPDES & National Pollutant Discharge Elimination System \\
\hline NPH & natural phenomena hazard \\
\hline NPR & New Production Reactor \\
\hline NRC & Nuclear Regulatory Commission \\
\hline OR & Operations Room \\
\hline ORNL & Oak Ridge National Laboratory \\
\hline ORR & Oak Ridge Reservation \\
\hline PA & protected area \\
\hline
\end{tabular}




\begin{tabular}{|c|c|}
\hline $\mathrm{PC}$ & performance category \\
\hline PDAC & pit disassembly and conversion \\
\hline PEL & peak electrical load \\
\hline $\mathrm{PF}$ & Plutonium Facility \\
\hline PFP & Plutonium Finishing Plant \\
\hline PHA & preliminary hazards analysis \\
\hline PIDAS & Perimeter Intrusion and Detection Assessment System \\
\hline PIE & postirradiation examination \\
\hline PPE & personal protective equipment \\
\hline PR & Preparation Room \\
\hline PSF & Plutonium Storage Facility \\
\hline PWR & pressurized-water reactor \\
\hline QA & quality assurance \\
\hline R\&D & research and development \\
\hline RAMROD & Radioactive Materials Research, Operations, and Demonstration Facility \\
\hline RCRA & Resource Conservation and Recovery Act of 1976 \\
\hline RCT & Radiological Control Technician \\
\hline RF & respirable fraction \\
\hline RH & remote handled \\
\hline RLWTF & Radioactive Liquid Waste Treatment Facility \\
\hline RMAL & Radioactive Materials Analytical Laboratory \\
\hline ROD & record of decision \\
\hline RPSF & Radioisotope Power Systems Facility \\
\hline RSSF & Radioactive Sodium Storage Facility \\
\hline RSWF & Radioactive Scrap and Waste Facility \\
\hline RWMC & Radioactive Waste Management Complex \\
\hline S\&D & storage and disposition \\
\hline S\&S & safeguards and security \\
\hline SAF & secure automated facility \\
\hline SCDHEC & South Carolina Department of Health and Environmental Control \\
\hline SEM & scanning electron microscope \\
\hline SIP & Space Isotope Program \\
\hline SNF & spent nuclear fuel \\
\hline SNFM & spent nuclear fuel material \\
\hline SNM & special nuclear material \\
\hline SP & sludge preparation \\
\hline SPSP & Space Power Systems Project \\
\hline SRS & Savannah River Site \\
\hline SRTC & Savannah River Technology Center \\
\hline SST & safe secure transport \\
\hline TA & Technical Area \\
\hline TAP & toxic air pollutant \\
\hline TEDE & total effective dose equivalent \\
\hline TR & Transfer Room \\
\hline TREAT & Transient Reactor Test Facility \\
\hline TRU & transuranic \\
\hline TSCA & Toxic Substances Control Act \\
\hline TSDF & treatment, storage, and/or disposal facility \\
\hline UBC & Uniform Building Code \\
\hline USF & Uranium Solidification Facility \\
\hline VOC & volatile organic compound \\
\hline W & Westinghouse \\
\hline WAG & Waste Area Group \\
\hline WCA & Waste Characterization Area \\
\hline
\end{tabular}




$\begin{array}{ll}\text { WCC } & \text { Waste Characterization Chamber } \\ \text { WCL } & \text { Waste Characterization Laboratory } \\ \text { WCRRF } & \text { Waste Characterization, Reduction, and Repackaging Facility } \\ \text { WDAS } & \text { Waste Data Acquisition System } \\ \text { WG } & \text { weapons grade } \\ \text { WIPP } & \text { Waste Isolation Pilot Plant } \\ \text { WOC } & \text { White Oak Creek } \\ \text { WRAP } & \text { Waste Receiving and Processing Plant } \\ \text { WSRC } & \text { Westinghouse Savannah River Company } \\ \text { ZPPR } & \text { Zero Power Physics Reactor }\end{array}$




\title{
SRS MOX FUEL LEAD ASSEMBLIES DATA REPORT FOR THE SURPLUS PLUTONIUM DISPOSITION ENVIRONMENTAL IMPACT STATEMENT
}

\author{
Project Manager \\ S. R. Greene \\ Lead Assembly EIS Data Project Lead and Author \\ D. G. O'Connor
}

\begin{abstract}
The purpose of this document is to support the U.S. Department of Energy (DOE) Fissile Materials Disposition Program's preparation of the draft surplus plutonium disposition environmental impact statement. This is one of several responses to data call requests for background information on activities associated with the operation of the lead assembly (LA) mixed-oxide (MOX) fuel fabrication facility.

The DOE Office of Fissile Materials Disposition (DOE-MD) has developed a "dual-path" strategy for disposition of surplus weapons-grade plutonium. One of the paths is to disposition surplus plutonium through irradiation of MOX fuel in commercial nuclear reactors. MOX fuel consists of plutonium and uranium oxides $\left(\mathrm{PuO}_{2}\right.$ and $\left.\mathrm{UO}_{2}\right)$, typically containing $95 \%$ or more $\mathrm{UO}_{2}$.

DOE-MD requested that the DOE Site Operations Offices nominate DOE sites that meet established minimum requirements that could produce MOX LAs. Six initial site combinations were proposed: (1) Argonne National Laboratory-West (ANL-W) with support from Idaho National Engineering and Environmental Laboratory (INEEL), (2) Hanford, (3) Los Alamos National Laboratory (LANL) with support from Pantex, (4) Lawrence Livermore National Laboratory (LLNL), (5) Oak Ridge Reservation (ORR), and (6) Savannah River Site (SRS). After further analysis by the sites and DOE-MD, five site combinations were established as possible candidates for producing MOX LAs: (1) ANL-W with support from INEEL, (2) Hanford, (3) LANL, (4) LLNL, and (5) SRS. Pantex was removed as a supporting organization to LANL because Pantex did not have facilities available that met the desired programmatic criteria. One of the criteria was that existing buildings would be used for the mission. Pantex had no available existing buildings that it was willing to propose for this limited mission. ORR was removed by DOE-MD from consideration because it lacked adequate Safeguards and Security (S\&S) Category I facilities, which would limit the quantity of material that could be processed at a given time.

SRS has proposed an LA MOX fuel fabrication approach that would be done entirely inside an S\&S Category I area. An alternate approach would allow fabrication of fuel pellets and assembly of fuel rods in an S\&S Category II or III facility with storage of bulk $\mathrm{PuO}_{2}$ and assembly, storage, and shipping of fuel bundles in an S\&S Category I facility.

The total Category I approach, which is the recommended option, would be done in the $221-\mathrm{H}$ Canyon Building. A facility that was never in service will be removed from one area, and a hardened wall will be constructed in another area to accommodate execution of the LA fuel fabrication.

The non-Category I approach would require removal of process equipment in the FB-Line metal production and packaging glove boxes, which requires work in a contamination area. The Immobilization Hot Demonstration Program equipment in the Savannah River Technology Center would need to be removed to accommodate pellet fabrication. This work would also be in a contaminated area.

A commercial reactor operator has not been identified for the LA irradiation. Postirradiation examination (PIE) of the irradiated fuel will take place at either Oak Ridge National Laboratory or ANL-W. The only modifications required at either PIE site would be to accommodate full-length irradiated fuel rods.

Results from this program are critical to the overall plutonium distribution schedule.
\end{abstract}


Page Intentionally Blank 


\section{INTRODUCTION AND SCHEDULE}

As part of the overall mission to disposition weapons-grade (WG) plutonium as fuel for commercial nuclear power plants, a lead assembly (LA) program is needed to qualify mixed-oxide (MOX) fuel as a safe and reliable fuel. The LA program will provide key data regarding the performance of MOX fuel in U.S. commercial reactors and supply information needed to modify current U.S. Nuclear Regulatory Commission (NRC) licenses. The program will also provide information necessary to validate and verify computer codes used in the reactor core design and accident analyses. In addition to qualifying the MOX fuel and validating and verifying the codes, the LA program will serve to verify that the United States can indeed execute each technical step necessary in the process of dispositioning plutonium as MOX fuel, except NRC licensing of facilities.

A simplified diagram showing each of the required process steps for the LA program is shown in Fig. 1. The LA program will include every step needed to complete the reactor portion of the plutonium disposition mission (including transportation and storage), with the exception of placement of the spent fuel in the geologic repository. In all likelihood, some of the LA program MOX fuel bundles will make their way to the geologic repository, but subsequent disposal in the repository is analyzed in other environmental documents. Detailed descriptions of the process required to fabricate MOX fuel, irradiate the fuel, and perform postirradiation examinations (PIE) of the spent fuel will be provided in Chaps. 3 and 10.

As previously stated, the goals of the LA program are to qualify the MOX fuel, confirm codes, and demonstrate that the United States can perform the steps necessary to disposition plutonium using MOX fuel. For the LA program these steps start with receipt of acceptable plutonium oxide $\left(\mathrm{PuO}_{2}\right)$ that is derived from "pits" and processed in the United States. At each step in the process, safeguards and security (S\&S) measures, material control and accountability (MC\&A) measures, transportation issues, storage issues, and material handling issues will be addressed. As shown in Fig. 1 , the $\mathrm{PuO}_{2}$ is mixed and blended with

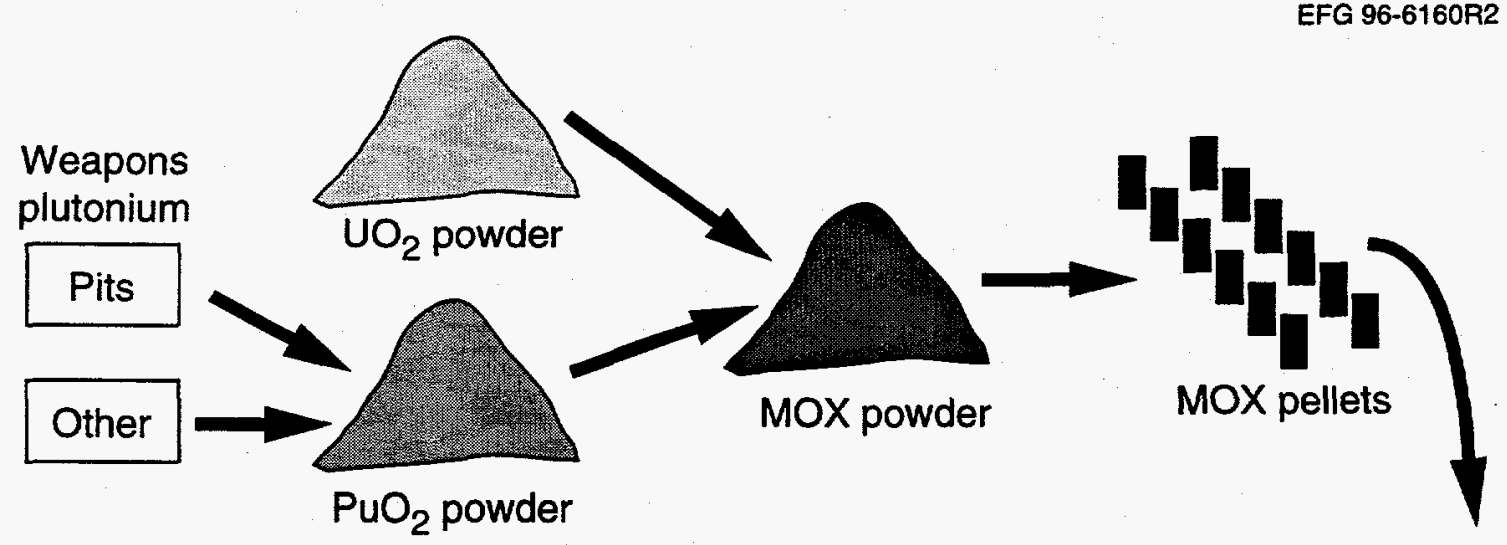

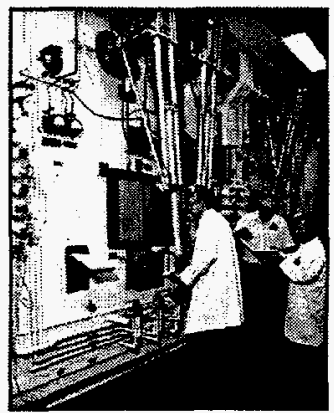

PIE

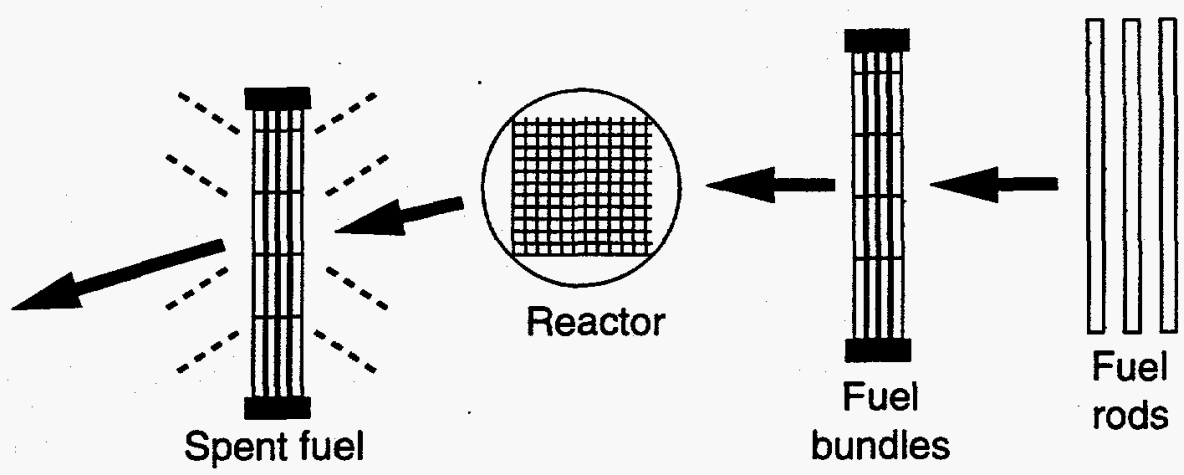

Fig. 1. Simplified LA process diagram. 
uranium oxide $\left(\mathrm{UO}_{2}\right)$ to arrive at the fissile content requested by the utility fuels engineer. Pellets are then pressed, sintered, and assembled into rods. The rods are then assembled into fuel assemblies and packaged for shipping to the reactor site for irradiation. After irradiating the fuel for one cycle, some of the rods are removed from the irradiated assemblies and taken to a laboratory for PIE. Additional rods will be removed after the second, third, and fourth cycles (if the chosen reactor has a third and fourth cycle), and PIE will be performed to confirm that the structural integrity of the MOX fuel, cladding, and assembly materials is maintained and that the computer codes accurately predict the fuel performance and evolution of fission products.

Figure 2 shows the anticipated schedule for the LA program relative to the plutonium disposition mission. Los Alamos National Laboratory (LANL) is currently developing the processes necessary to fabricate MOX fuel. The U.S. Department of Energy Office of Fissile Materials Disposition (DOE-MD) plans to choose a consortium before the end of 1998 to disposition excess plutonium using reactors, at which time this consortium will choose the DOE site(s) and associated facilities to fabricate the LA MOX fuel. At that same time the consortium will begin design, licensing, and construction of the mission MOX fuel fabrication facility. The fabrication process used for the LAs will be as close as possible to that of the MOX fabricator in the consortium. Fabrication of the LA MOX fuel will begin in late 2002. The first LAs [shown as lead-test assemblies (LTAs) in Fig. 2] will be available for insertion in a commercial reactor in late 2003. PIE will begin 6 months after completion of the first reactor cycle with results available by the end of the second LA reactor cycle. After two LA cycles (18-24 months per cycle), the mission MOX fuel fabrication will begin if the PIE produces satisfactory confirmation of fuel performance. PIE will be done after each LA reactor cycle to ensure that fuel performance meets or exceeds expected results. Table 1 provides the schedules associated with the design, modification, operation, decontamination and decommissioning (D\&D), and/or conversion of the LA MOX fuel fabrication facility. Table 2 provides the time frames associated with the LA testing.

To maintain LA fabrication capability, should it be needed for any reason, the LA fuel fabrication facility will be maintained in standby for 4 years between the end of the facility's scheduled operation and its scheduled D\&D. During this time the capability to produce lead assemblies will be maintained.

A maximum of ten LAs will be produced to mee the LA program mission goals. Table 3 provides the anticipated quantities of constituent materials that will be needed annually and in total to complete the LA program. Several assumptions were made to arrive at the quantities in Table 3 , and these are listed in Table 4.

A total of four assemblies are anticipated to be required for use as LAs in the chosen mission reactor. It is possible a second set of four LAs will be needed for either a second reactor or for use in the same reactor. In addition, sufficient rods will be produced to assemble two archive LAs.

A total of eight LA MOX fuel assemblies will be temporarily stored in the LA fabrication facility until they are shipped to the reactors for irradiation. The rods for the two remaining assemblies, and possibly the MOX rods from four assemblies not used, will be retained in the LA shipping and storage area as archive rods. These archive rods will be used if needed as replacement rods in the reactor or they may be used for tests of the LA MOX fuel fabrication process. If they are not needed, or until they are needed, these rods will be stored at the LA MOX fuel fabrication facility until the end of that facility's mission. The LAs will then be shipped to the mission MOX fabrication facility for storage until the end of the Fissile Materials Disposition Program, at which time they will either be retained by the consortium as active rods, or irradiated in a mission reactor.

Due to the uncertainty associated with the final design of the LA MOX fuel, the assemblies may consist of either all MOX fuel rods or a combination of low-enriched uranium (LEU) and MOX rods. A bounding approach was taken in considering environmental impacts. The bounds that were considered for this report were based on the number of MOX fuel rods per assembly. A lower bound of one-third of the fuel rods being MOX rods results in the need to ship the remaining two-thirds of the required LEU rods to the LA fuel fabrication facility. The upper bound of all MOX rods in the assembly provides the bounding case for resource needs, safety considerations, accident analyses, and postirradiation examination. 
ORNL-DWG 97-1915R3 EFG

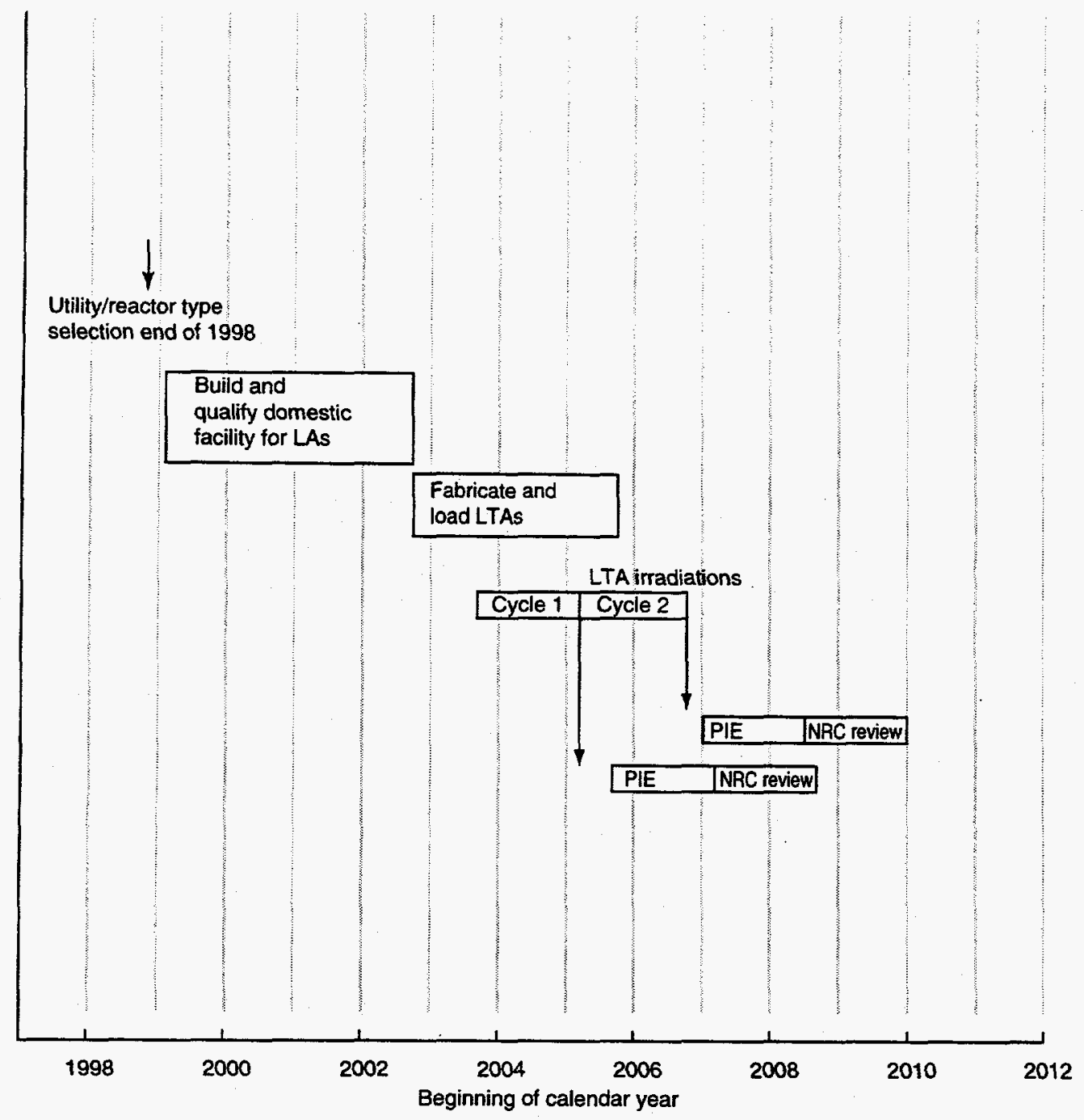

Fig. 2. LA program schedule. 
Table 1. LA fabrication facility schedule

\begin{tabular}{ll}
\hline \multicolumn{1}{c}{ Activity } & \multicolumn{1}{c}{$\begin{array}{c}\text { Time frame } \\
\text { (beginning and end) }\end{array}$} \\
\hline Equipment procured & June 2000-December 2001 \\
Facility design & February 1999-January 2001 \\
Facility permitting & January 2000-January 2002 \\
Facility modification & January 2000-February 2002 \\
Facility startup & February 2002-October 2002 \\
LA fabrication (operation) & October 2002-October 2005 \\
LA fabrication facility standby & October 2005-January 2010 \\
D\&D and/or conversion phase & January 2010-January 2013 \\
\hline
\end{tabular}

Table 2. LA testing schedule

\begin{tabular}{ll}
\hline \multicolumn{1}{c}{ Activity } & \multicolumn{1}{c}{ Time frame (beginning and end) } \\
\hline Irradiation & $\begin{array}{l}\text { September 2003-October 2006 } \\
\text { Removal (cooldown) }\end{array}$ \\
March 2005-October 2006 (6 months cooldown after removal \\
before PIE, March 2005-April 2007) \\
PIE & $\begin{array}{l}\text { September 2005-October 2008 (about 18 months for PIE for each } \\
\text { reactor cycle) }\end{array}$ \\
\hline
\end{tabular}

Table 3. LA MOX fuel material requirements

\begin{tabular}{lccccr}
\hline Material & $\begin{array}{c}\text { Startup } \\
\text { requirement }\end{array}$ & $\begin{array}{c}\text { Startup } \\
\text { scrap/recyclable }\end{array}$ & $\begin{array}{c}\text { Maximum } \\
\text { annual } \\
\text { requirement }\end{array}$ & $\begin{array}{c}\text { Maximum } \\
\text { annual scrap/ } \\
\text { recyclable }\end{array}$ & $\begin{array}{c}\text { Total } \\
\text { quantity }\end{array}$ \\
\hline $\begin{array}{l}\text { Plutonium, kg } \\
\text { heavy metal (HM) }\end{array}$ & 21 & 13 & 120 & 20 & 321 \\
$\begin{array}{l}\text { Depleted uranium, } \\
\text { kg HM }\end{array}$ & 867 & 250 & 2,400 & 400 & 6,867 \\
$\begin{array}{l}\text { Pellets } \\
\text { Rods }\end{array}$ & 221,760 & & 532,224 & & $1,552,320$ \\
Bundles & 440 & & 1,162 & & 3,344 \\
& & 4 & & 10 \\
\hline
\end{tabular}

Note: In the event LEU rods are used in place of some MOX rods in the assembly, the total quantities of plutonium will be reduced by the amount of LEU introduced. The maximum contribution of LEU rods is twothirds of the total assembly rods. 
Table 4. Assumptions made to determine LA MOX fuel material requirements

1. Material and process requirements are based on producing pressurized-water reactor $(P W R)$ fuel.

2. $\mathrm{PuO}_{2}$ powder will meet the American Society for Testing and Materials (ASTM) specification C 757-90 as received.

3. Depleted $\mathrm{UO}_{2}$ powder will meet the ASTM specification as received.

4. Depleted $\mathrm{UO}_{2}$ (no $\mathrm{PuO}_{2}$ ) will be used to perform all system shakedown tests before introducing plutonium.

5. Table 3 is in terms of $\mathrm{HM}$. The factor for converting $\mathrm{PuO}_{2}$ and depleted $\mathrm{UO}_{2}$ to $\mathrm{HM}$ is $88 \%$.

6. All waste plutonium will be canned and sent to the Immobilization Program for final disposition.

7. All plutonium scrap will be recycled using a dry process.

8. All liquid wastes generated are ancillary to the base process (i.e., laundry, mop water, etc.).

9. Sintering furnaces will stay at temperature during the entire 3-year mission and 1-year startup.

10. Sintering furnaces will be purged with a mixture of argon and $6 \%$ hydrogen at a rate of $10 \mathrm{~L} / \mathrm{min}$.

11. Powder glove boxes will be purged with nitrogen to reduce the potential for oxidizing $\mathrm{UO}_{2}$.

12. All calculated numbers have a precision of no more than two significant figures.

13. Homogenization of the $\mathrm{PuO}_{2}$ will be done at the LA fuel fabrication facility, as will gallium removal operations. 
Page Intentionally Blank 


\section{SITE MAP AND THE LA FACILITY DESCRIPTION}

\subsection{SITE LOCATION}

\subsubsection{Site Description}

The Savannah River Site (SRS) is located in portions of Aiken, Allendale, and Barnwell counties in western South Carolina. It occupies a nearly circular area of $\sim 310$ miles $^{2}$ bounded on the west by the Savannah River and centered 25 miles southeast of Augusta, Georgia. An SRS map is provided in Fig. 3. ${ }^{1}$ SRS is owned by the U.S. government and was set aside in 1950 by the U.S. Atomic Energy Commission (AEC) as a controlled area for the production of special nuclear materials (SNMs), primarily plutonium and tritium, for national defense. With Bechtel Savannah River, Inc.; Babcock and Wilcox; and British Nuclear Fuels, Ltd.; Westinghouse Savannah River Company currently manages and operates the facility for DOE. SRS includes $\sim 2862$ buildings with several million square feet of floor area and an additional 4800 supporting facilities and structures. In addition to the 20 major areas that have been in use at SRS, an additional 20 sites have been identified and given preliminary evaluations as industrial sites. These range in size up to 2200 acres. The layout of SRS is intended to concentrate major radioactive materials operations near the center of the site. This feature creates a buffer zone of woods, wetlands, and cleared land to reduce the risk of accidental radiation exposure of the public and to facilitate site security. The total on-site work force is 15,000 employees.

\subsubsection{Summary of MOX Site Evaluation}

Based on preconceptual design assumptions, several locations were evaluated as potential MOX LTA fabrication sites. For the purpose of the environmental impact statement (EIS) analysis, a facility located within the 221-H Canyon Facility in unused space that was constructed for the Uranium Solidification Facility (USF) (but never completed) has been chosen as the recommended facility for the Category I LA fabrication facility (Fig. 4). As shown on the site map, this area is within the 6 -mile-diam central area containing the radioactive material at SRS. The SRS former USF is considered the most feasible location; however, the following modifications and work activities are required in addition to installation of the MOX process equipment:

- removal of installed USF equipment and unusable support systems currently in the area;

- modification of the Materials Access Area (MAA) security zone;

- installation of a heating, ventilating, and air-conditioning (HVAC) system to provide properly zoned ventilation and air filtration for the facility; and

- modification of electrical, lighting, and security system installations.

\subsubsection{Summary of Alternative Investigations}

Other facilities within the F and $\mathrm{H}$ Areas are considered feasible locations for the MOX demonstration program (Figs. 5 and 6). One of these alternate locations may well be the preferred option after further detailed design development and evaluation. Current information from the investigation, however, has indicated that use of alternative facilities within the $\mathrm{F}$ and $\mathrm{H}$ Areas would not result in significantly different results to what is considered to be a minimal environmental impact.

One of the proposed alternatives, the non-Category 1 Option, may be more cost-effective. Details of this option are also included. 
ORNL-DWG 97-3221 EFG

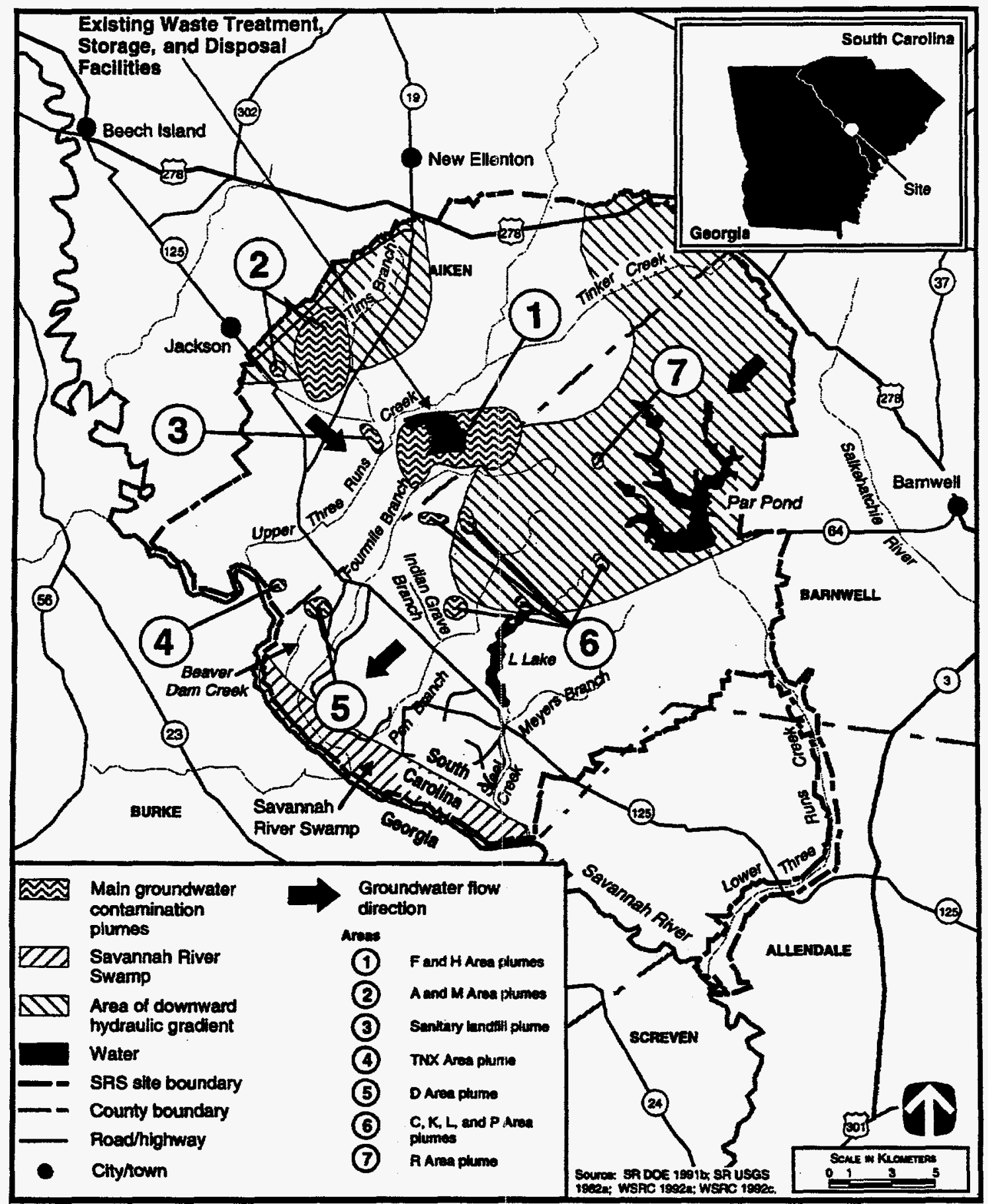

Fig. 3. SRS area map. Source: Storage and Disposition of Weapons-Usable Fissile Materials Final Programmatic Environmental Impact Statement, Vol. 1, DOE/EIS-0229, U.S. Department of Energy, December 1996. 
ORNL-DWG 97-2866 EFG

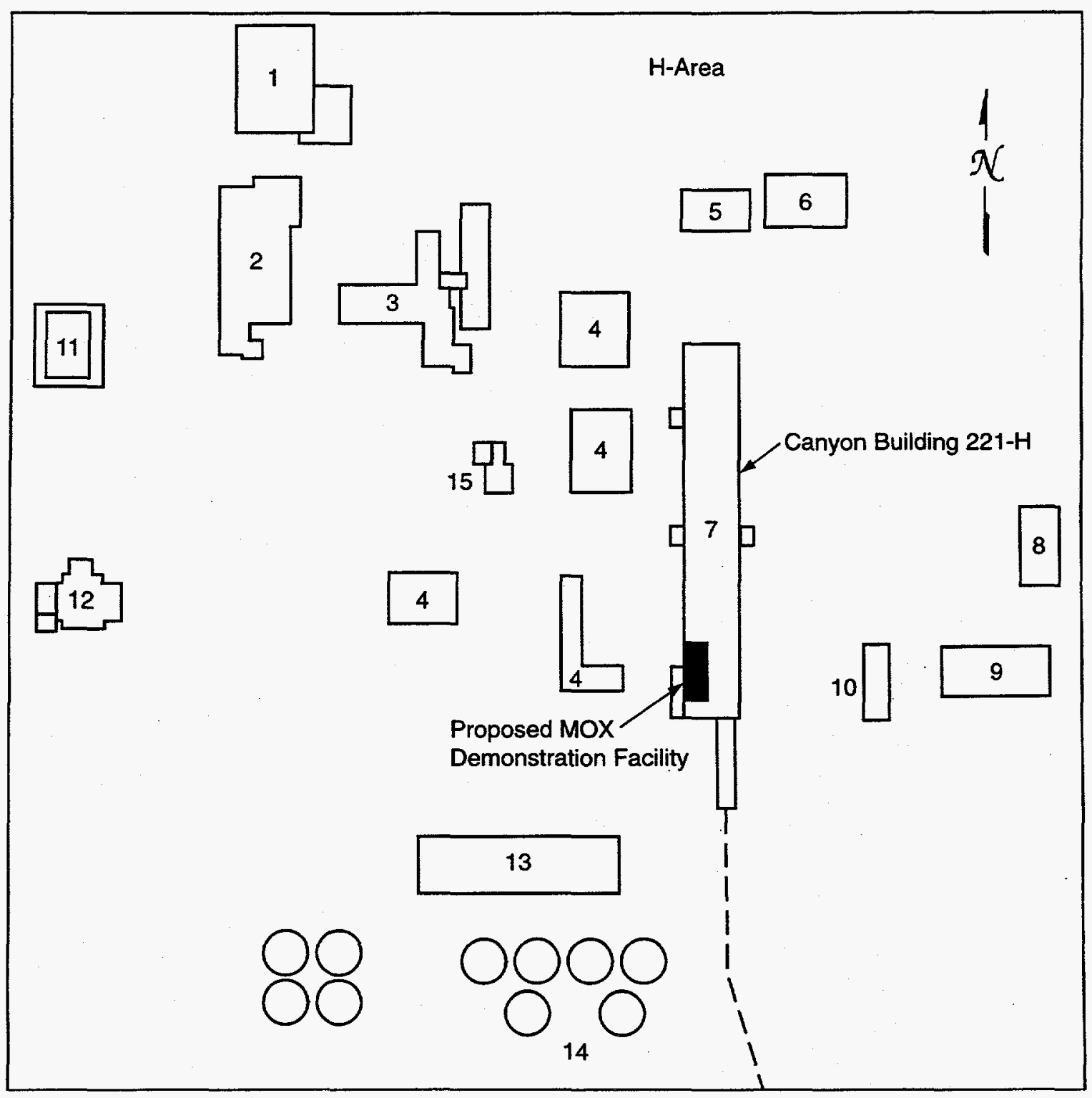

Fig. 4. Category I MOX facility proposed site. 


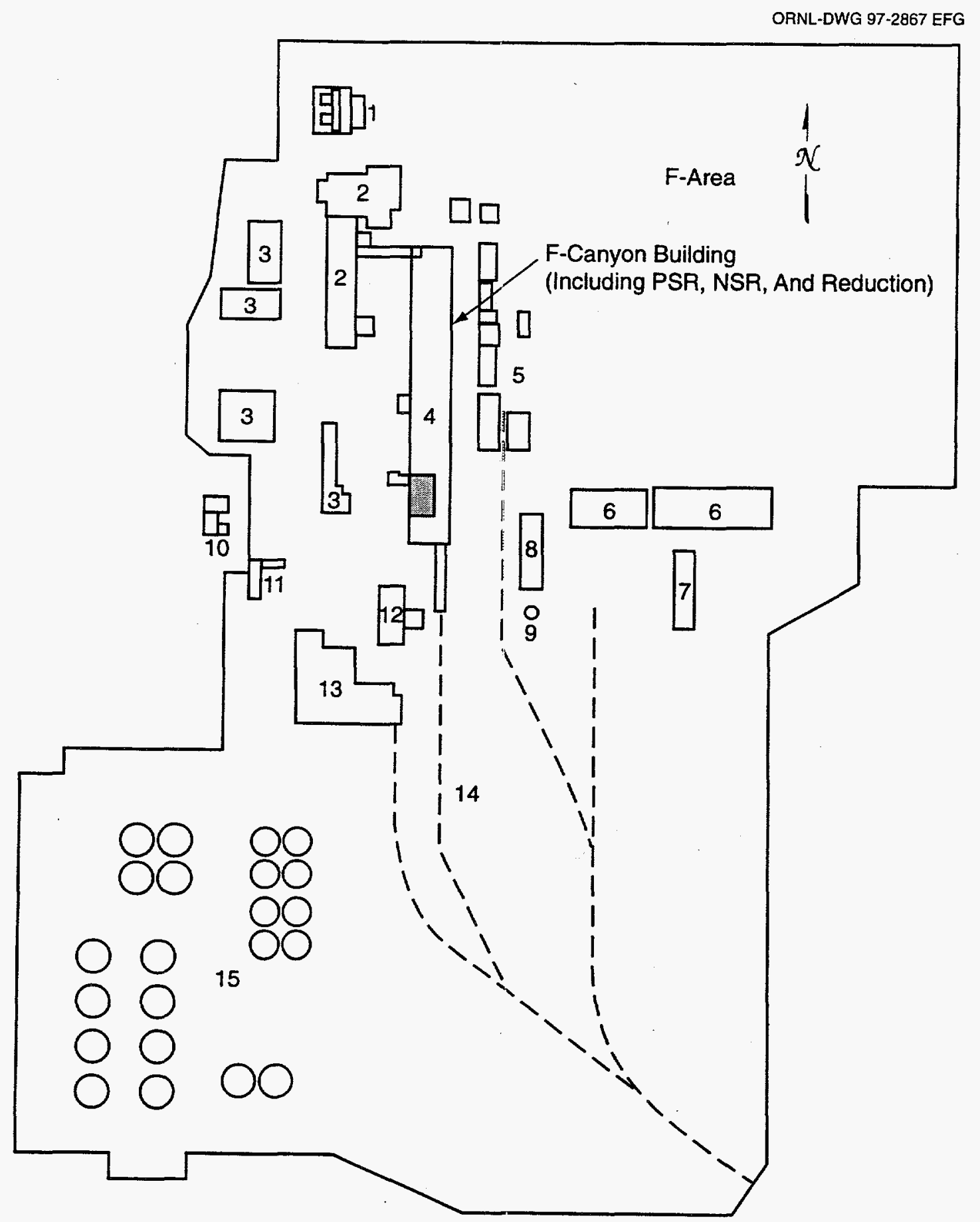

[0.0

Fig. 5. Non-Category I alternative powder preparation location. 


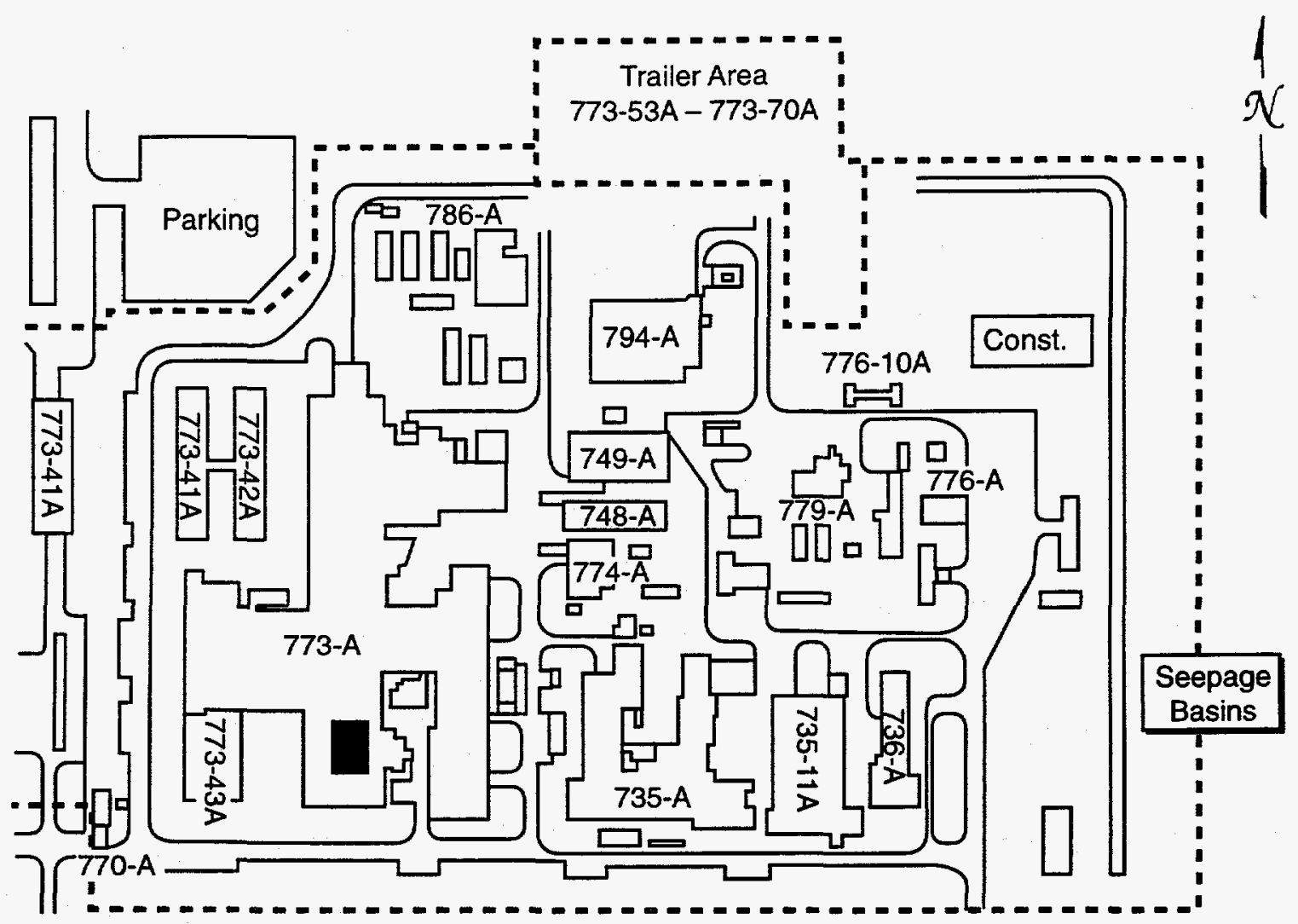

Proposed MOX Pellet Fabrication and Rod Fill Location

Fig. 6. Non-Category I facility alternative pellet fabrication and rod fill location.

A summary of the site infrastructure available to support a MOX demonstration fabrication mission includes the following:

1. Services

- central laboratory facilities

- communications systems

- laundry service

- telephone and computer network

- pagers and radio systems

- cafeterias

- S\&S facilities, including an active protective force

- fire protection services

- central construction

2. Facilities

- central stores and receiving

- rail and roadway service

- central computing facilities

- medical

- waste management

- environmental monitoring

- technology capabilities

- electric and steam utilities 
Other required infrastructure elements such as fire and emergency response departments, security, transportation, environmental monitoring, training, laboratories, and central maintenance facilities are available and adequate for use for the MOX facility. The security equipment in the area will require upgrading to current standards before use.

SRS has extensive site experience and capability in SNM recovery and radioactive waste management. Included are currently operating facilities capable of purifying $\mathrm{PuO}_{2}$ feed, reconditioning and purifying MOX process contaminated wastes, TRU waste management and disposition, and contaminated liquid waste recovery and disposition. The site has an approved plan being implemented for treatment of mixed waste (MW). Anticipated MOX radioactive and nonradioactive waste streams (solid, liquid, and gaseous) are consistent with the permitted activities at the site.

Management, administration, programmatic [as low as reasonably achievable (ALARA), training, and quality assurance], and independent external and internal oversight functions are in place and available to interface where appropriate with those of the MOX facility operator.

\subsubsection{Facilities Data}

\subsubsection{Filtration used by buildings}

Buildings 221-F and - $\mathrm{H}$ and 773-A C-Wing use triple high-efficiency particulate air (HEPA) filtration (single HEPA glove boxes, double HEPA at the buildings) and exhaust to a final sand filter prior to stack discharge.

\subsubsection{Radiation doses during modification}

Radiological impact during construction for the non-Category I option. The proposed project will modify existing glove boxes in the Savannah River Technological Center (SRTC) C-Wing process room and in the 200-F Area Canyon building fifth-level FB-Line Mechanical Line and will install new equipment for bundle assembly in the H-Canyon building. The FB-Line is assumed to have the highest radioactivity relative to the other two locations; thus, it is used for estimating additional radioactive impact (if any) to workers and the public during construction.

Radiological impact to employees. During previous fuel processing in the FB-Line facility, the maximum individual worker exposure was estimated at $0.44 \mathrm{rem} / \mathrm{year}$, and the average worker exposure was estimated at $0.14 \mathrm{rem} /$ year. Additionally, $\mathrm{H}$-Canyon maximum exposure was $0.04 \mathrm{rem} / \mathrm{year}$, and the average was $0.01 \mathrm{rem} / \mathrm{year}$. The SRTC maximum was $0.08 \mathrm{rem} / \mathrm{year}$, and the average was $0.06 \mathrm{rem} / \mathrm{year}$.

Radiological impact during construction for the Category I option. The proposed project will upgrade the existing USF facility in the 221-H Canyon building. The USF facility has not been operated and is not expected to have additional radioactive impact to workers and the public during construction.

Radiological impact to employees. During previous fuel processing in the H-Canyon facility, the maximum individual worker exposure was estimated at $0.04 \mathrm{rem} / \mathrm{year}$, and the average worker exposure was estimated at $0.01 \mathrm{rem} / \mathrm{year}$.

\subsubsection{Building dimensions}

Building $221-\mathrm{F}$ and $-\mathrm{H}$ dimensions are $821 \mathrm{ft}$ in length (n-s), $122 \mathrm{ft}$ in width (e-w), and $51 \mathrm{ft}-6 \mathrm{in}$. in height (above grade) at sections 1 and 2. Building 773-A dimensions are $457 \mathrm{ft}$ in length (n-s), $421 \mathrm{ft}$ in width (e-w), and $27 \mathrm{ft}-8 \mathrm{in}$. in height. Note that C-Wing is $223 \mathrm{ft}$ long, $112 \mathrm{ft}-6 \mathrm{in}$. wide, and two-story $27 \mathrm{ft}-8 \mathrm{in}$. high with part of the first level below grade.

\subsubsection{Building 773-A stack height and $C$-Wing seismic information}

The main SRTC Building 773-A is comprised of six wings (A-Wing through F-Wing) and two stacks associated with the $\mathrm{B}$ - and $\mathrm{C}$-Wings. 
The wings with a radiological hazard (B-, C-, E- and F-Wings) and the two stacks have been analyzed for natural phenomena hazards (NPHs) in accordance with DOE Standard 1020-94 with Change Notice 1, January 1996.

The SRTC Building 773-A C-Wing was analyzed in 1997 and found to meet completely the seismic requirements of DOE-STD-1020 for Performance Category (PC) 3. However, under wind and tornado forces the 1/4-in. transite (asbestos-reinforced cementitous material) sheathing on the outside of the building will fail. The siding failure does not lead to failure of the reinforced concrete frame of the building. The siding failure is at approximately the PC 2 wind level.

The B-and C-Wings exhaust stacks are $75 \mathrm{ft}$ high. Because of the proximity of the stacks to the B-, $\mathrm{C}-$, and E-Wing, NPH analysis was performed to ensure structural integrity. The stacks were found to meet ACI 307 code criteria for PC 3 seismic, wind, and tornado levels.

\subsection{ASSUMPTIONS}

Key parameters of the LA process description as developed by Oak Ridge National Laboratory (ORNL) and DOE-MD are as follows:

1. The MOX demonstration facility will not require NRC licensing and will be developed following DOE orders and potential International Atomic Energy Agency (IAEA) safeguards for nuclear facilities.

2. Process feed is $\mathrm{PuO}_{2}$ and depleted $\mathrm{UO}_{2}$ that meets all powder specification requirements. For the purpose of this assessment, preparation of the feed materials, including removal of contaminants, is not included in the scope of the process. The material will be suitable for the employee-operated workstations proposed, because this demonstration facility is not planned to be highly automated.

3. LWR fuel is produced with 5\% plutonium loading. An assumed 5\% scrap rate results in total annual MOX throughput of $2 \mathrm{MT}$ HM per year.

4. Fuel bundle components other than MOX pellets (caps, springs, skeletons, cladding tubes, absorber rods, and $\mathrm{UO}_{2}$ ) are purchased from off-site suppliers for assembly at the MOX facility.

5. The facility will produce three PWR MOX assemblies per year.

6. On-site storage capability for six MOX fuel assemblies will be provided.

Major functional areas of the LA fabrication process are as follows:

- $\mathrm{PuO}_{2}$ and $\mathrm{UO}_{2}$ receiving and storage

- MOX powder preparation and storage (i.e., powder blending, milling, granulation, and addition of additives)

- fuel pelletizing and storage

- sintering and storage

- pellet grinding, inspection, and storage

- fuel rod loading and storage

- fuel rod inspection and storage

- fuel bundle assembly and storage

Process support operations include the following:

- scrap recovery, processing, and disposition

- analytical services

- process monitoring

- waste collection and packaging for off-site disposition

- accountability

- utilities (power, water, sanitary waste, roads, and process gas)

- support services (fire, medical, emergency response, environmental monitoring, communications, training, maintenance facilities, and analytical services facilities)

- material recovery, waste treatment, and waste management facilities and experience

- S\&S [access controls, Perimeter Intrusion and Detection Assessment System (PIDAS), protective force, safe secure transport (SST) vehicle receiving and shipping facility, and storage] 
- administration and management (internal and external safety and SNM oversight organization and activities, an ALARA program, emergency planning, quality control, SNM MC\&A systems)

\subsection{CATEGORY I RECOMMENDED MOX OP'TION}

\subsubsection{Description of Project Work}

Dismantling and Rearrangement (D\&R). The former USF process modules will be removed from the facility, along with associated interconnecting piping and electrical/instrumentation. The USF denitration and packaging equipment will also be dismantled and removed. This equipment was never placed in service and is expected to be cleared as not contaminated for removal and release to general scrap. The basic USF structural envelope including security features on $221-\mathrm{H}$ first- and second-level floors will be reviewed and reused to the maximum extent possible. The AL room on the first level will be essentially maintained as installed to support the MOX processing requirements. Existing USF fire protection, electrical distribution, utilities, and ventilation supply will be used. Access control, locker rooms, administrative space and waste management activities that USF intended to share with HB-Line, will be reestablished for MOX purposes. The tenant relation with the $\mathrm{H}$-Canyon landlord will be arranged.

\subsubsection{MOX Facilities}

Freestanding glove boxes will be provided as required to contain the MOX demonstration fuel fabrication equipment. An orderly arrangement of receipt, storage, analysis, manufacture, and inspection will be laid out and constructed within the $6000-\mathrm{ft}^{2}$ area over the two floor levels. Category I vault storage, as well as product space to hang six bundles, will be accommodated. All waste generated will be collected for removal through HB-Line packaging and management facilities. An additional area allocated from Canyon operation storage space immediately south of the former USF area will be assimilated with the MOX MAA by construction of hardened confinement walls. Bundle packaging and exhaust ventilation will be designed and arranged within this space.

\subsubsection{Unique Features of the MOX Facility}

The MOX MAA will be integrated with the HB-Line but will be on separate floor levels and can be accessible to foreign nationals if they are required to view the MOX facility, without the necessity to directly access the HB-Line. Also, if it is desirable to provide plutonium feed from HB-Line, it will be available from within the same material accountability area. The MOX facility will include all process requirements in a single location including bundle storage. The H-Area infrastructure will support the MOX program.

\subsection{NON-CATEGORY I ALTERNATE MOX OPTION}

\subsubsection{General Discussion}

This alternative provides a methodology whereby it is feasible to develop a MOX demonstration fuel fabrication program that provides a sequence of material flow and arrangement of equipment between SRTC and the Office of Nuclear Material Stabilization and Storage (NMSS) facilities so that reduced security requirements could be considered for the processing portion of the program, after the preparation of the $20 \%$ master blend. The work to be performed in the identified areas would rely on the support facilities and infrastructure of the respective areas. To accomplish this, processing would need to be arranged as described in the following sections. 


\subsubsection{Blending Process Description}

An FB-Line would be used for Category I plutonium feed of suitable isotopic content to allow handling in workstations that are not highly automated, and it would be received and stored in FB-Line facilities. Containment in the FB-Line that was modified to accommodate MOX powder preparation (powder final blending, milling, granulation, and additives) and a blending apparatus would be used to blend $\mathrm{PuO}_{2}$ with depleted uranium to a master blend before final blending to the desired $\mathrm{PuO}_{2}$ concentration, which will vary.

\subsubsection{MOX Demonstration Fuel Processing Description}

The SRTC laboratory would be used for Category II or Category III operations. Upon completion of the Immobilization Hot demonstration in FY 2000, the laboratory equipment and the containment line will be modified, and equipment will be installed for handling the MOX feed through

- fuel pelletizing

- sintering

- pellet grinding and inspection

The blended MOX powder will allow a Category II or Category III operation to be performed at SRTC. After the pelletizing step, the pellet product will be loaded into rods and inspected. The MOX fuel rods will then be packaged for transport to H-Canyon for bundle assembly. The laboratory operation would then again receive blended material so as to maintain the limited security limitation at SRTC, and the operation would be repeated again.

\subsubsection{Bundle Assembly and Storage Description}

An area allocated from H-Canyon operation storage space immediately south of the former USF area will be assimilated with MOX MAA by construction of hardened confinement wells. Bundle packaging and exhaust ventilation will be designed and arranged within this space. This area will be used to assemble MOX fuel bundles from fuel rods fabricated at the SRTC. Fuel assemblies will be stored in suitable hanging racks or shipping casks until they are shipped to designated reactors.

\subsubsection{Non-Category I Project Work Description}

\subsubsection{FB-Line description of work}

D\&R. The scheduled mission of the FB-Line facility to produce plutonium metal will be complete in FY 2000, but the facility vaults and packaging operations will remain in operation through FY 2002 . There are no plans to deactivate the facility within the next decade; therefore, facilities essential for plutonium feed preparation for a MOX demonstration will be available for use. Process equipment within the existing FB-Line metal production and packaging glove boxes will be dismantled and removed, which requires work in a contamination area. The dismantled equipment will be packaged and stored. With greater detail of process equipment, it may be necessary to modify or replace an existing workstation in FB-Line.

Existing FB-Line SNM receiving capability, bagless transfer, general ventilation, and support provided by the existing facility will be utilized. The S\&S features of the FB-Line will be maintained for the MOX demonstration mission.

MOX powder preparation station. Glove boxes will be used for MOX powder preparation. The final blend will be packaged for intrasite shipment. Existing FB-Line and 772-F laboratory analytical capability will be utilized.

\subsubsection{SRTC description of work}

D\&R. The Immobilization Hot Demonstration Program will be complete in FY 2000, and the facility will be available for MOX demonstration use. Immobilization surplus equipment will be dismantled and 
removed. This will require work in a contamination area. The removed equipment will be packaged and stored. The details of the removal and reuse of some equipment have not been investigated in detail at this time.

MOX pellet fabrication and rod loading facilities (non-Category I quantities). The existing immobilization glove boxes will be used to contain the MOX demonstration fuel fabrication equipment. No significant modification to the containment glove boxes is planned. An arrangement to accomplish the MOX demonstration fuel fabrication will be undertaken utilizing presses and furnaces from the existing immobilization equipment to the extent possible as well as receipt and packaging features that remain. Additional equipment for pellet grinding will be provided. Waste handling, inspection, and analytical capabilities of the SRTC will be used. Once acceptable MOX pellets are achieved, they will be loaded into rods and packaged for intrasite shipment to $\mathrm{H}$-Canyon.

\subsubsection{H-Canyon description of work}

D\&R. It is assumed that the H-Canyon space remains unused and is available for the MOX demonstration mission. No significant $D \& R$ is planned. Sufficient free space is judged available to install the MOX fuel bundle assembly equipment. Space will also be modified to accommodate bundle storage.

MOX fuel bundle assembly and storage. A bundle assembly station and final inspection facilities will be arranged as well as bundle storage, cask handling, and shipping. The $S \& S$ provisions will need to be defined and the existing features possibly modified to meet requirements. Support services and personnel facilities will be utilized from existing facilities. 


\section{PROCESS DESCRIPTIONS}

\subsection{PROCESS FLOW DIAGRAM}

A process block flow diagram is provided in Fig. 7. Assumptions for the process were given in Table 4. Figure 7 provides the total quantity of HM throughput that is anticipated at each step of the process for an entire year of operations after the facility reaches steady state.

To achieve a state of reliable operations for the new facility, cold startup and hot startup phases are anticipated to be necessary. Table 5 provides the anticipated material requirements for each phase of the startup and operations for the LA MOX fuel fabrication facility. The cold startup consists of using only depleted $\mathrm{UO}_{2}$ in the fuel fabrication process to develop acceptable processing steps.

Hot startup consists of using the final MOX fuel blend to determine that each processing step meets acceptable standards of fuel quality and repeatability. This phase of startup is anticipated to require at least 6 months.

\subsection{WASTE MANAGEMENT FLOW DIAGRAMS}

Figure $8(a)$ and $(b)$ are simplified flow diagrams that indicate how all forms of waste from the LA MOX fuel fabrication facility will be handled and disposed. These flow diagrams are generic examples of how waste will be handled for each site. Of course, each site will have some site-specific variations from the given flow diagrams, but for the purposes of this study the given material flow diagrams should be adequate.

For SRS, liquid low-level waste (LLW) will be processed at the liquid LLW treatment plant, solid transuranic (TRU) waste will be stored at the TRU waste management complex in the E Area, solid LLW will be compacted and transferred to the LLW burial vaults for disposal in E Area, and TRU waste will be disposed at WIPP. 


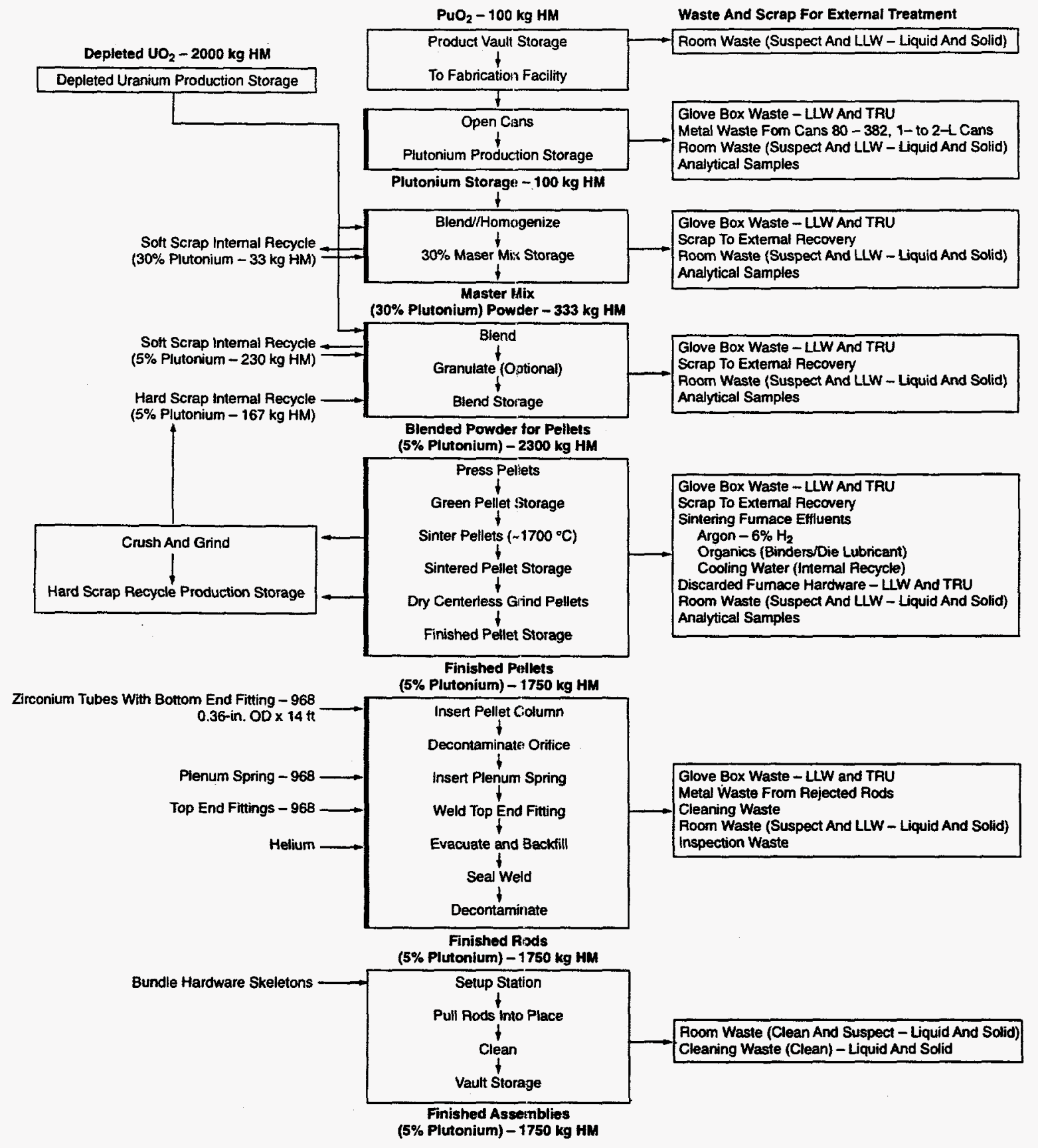

Note: 1 . Heavy borders are glove box process operations.

2. A total of $20 \%$ of pellets will be recycled.

Fig. 7. LA MOX fuel flow sheet outline with annual throughputs. 
Table 5. LA MOX fuel fabrication requirements

\begin{tabular}{|c|c|c|c|c|c|c|c|c|c|c|}
\hline & \multirow[b]{2}{*}{ Units/bundle } & \multicolumn{2}{|c|}{ Product produced $^{a}$} & \multirow[b]{2}{*}{$\begin{array}{l}\text { Cold } \\
\text { startup }\end{array}$} & \multirow[b]{2}{*}{$\begin{array}{l}\text { Hot startup } \\
\text { (6 months) }\end{array}$} & \multicolumn{4}{|c|}{ Production capacity required $^{a}$} & \multirow[b]{2}{*}{ Total } \\
\hline & & $\begin{array}{l}\text { Output- } \\
3 \text { years }\end{array}$ & $\begin{array}{l}\text { Output- } \\
1 \text { year }\end{array}$ & & & $\begin{array}{c}\text { Rejection } \\
\text { rate }^{b}\end{array}$ & $\begin{array}{l}\text { Capacityl } \\
3 \text { years }\end{array}$ & $\begin{array}{l}\text { Capacity/ } \\
\text { I year }\end{array}$ & $\begin{array}{l}\text { Capacity/d } \\
(200 \mathrm{~d} / \text { year })\end{array}$ & \\
\hline \multicolumn{11}{|l|}{ Base requirements and assumptions } \\
\hline Bundles/year [pressurized-water reactor (PWR) $17 \times 17$ ] & & 10 & 3 & & & $0 \%$ & 10 & 3.3 & & 10 \\
\hline Rods & 264 & 2,640 & 880 & 220 & 220 & $10 \%$ & 2,904 & 968 & 5 & 3,344 \\
\hline Pellets $(0.327$-in, diam $\times 0.4$ in. $\times 14 \mathrm{ft})$ & 110,880 & $1,108,800$ & 369,600 & 110,880 & 110,880 & $20 \%$ & $1,330,560$ & 443,520 & 2,218 & $1,552,320$ \\
\hline \multicolumn{11}{|l|}{ Plutonium and depleted uranium required } \\
\hline Plutonium ( $5 \%$ in depleted uranium), $\mathrm{kg} \mathrm{HM}^{c}$ & 25 & 250 & 83 & & 21 & $20 \%$ & 300 & 100 & 0.5 & 321 \\
\hline Depleted uranium, $\mathrm{kg} \mathrm{HM}$ & 500 & 5,000 & 1,667 & 450 & 417 & $20 \%$ & 6,000 & 2,000 & 10 & 6,867 \\
\hline Total plutonium + depleted uranium, $\mathrm{kg} \mathrm{HM}^{c}$ & 525 & 5,250 & 1,750 & 450 & 438 & $20 \%$ & 6,300 & 2,100 & 11 & 7,188 \\
\hline \multicolumn{11}{|l|}{ Scrap generation } \\
\hline Total scrap depleted uranium, $\mathrm{kg} \mathrm{HM}$ & & & & 450 & & & & & & $450^{d}$ \\
\hline $\begin{array}{l}\text { Total scrap plutonium (mixed with depleted uranium), } \\
\text { kg HM }\end{array}$ & & & & & 13 & & 51 & 17 & 0.1 & $64^{d}$ \\
\hline $\begin{array}{l}\text { Total scrap depleted uranium (mixed with plutonium), } \\
\mathrm{kg} \mathrm{HM}\end{array}$ & & & & & 250 & & 1,000 & 333 & 2 & 1,250 \\
\hline \multicolumn{11}{|l|}{ Recycle and recovery scrap and waste quantities } \\
\hline $\begin{array}{l}\text { Recycled hard scrape (mixed with depleted uranium), } \\
\text { kg HM }\end{array}$ & & & & & 6.25 & & 25 & 8 & & 31 \\
\hline $\begin{array}{l}\text { Recycled hard scrap depleted uranium (mixed with } \\
\text { plutonium), kg HM }\end{array}$ & & & & & 125 & & 500 & 167 & & 625 \\
\hline $\begin{array}{l}\text { Scrap plutonium to recovery (mixed with depleted } \\
\text { uranium), kg HM }\end{array}$ & & & & & 5 & & 21 & 7 & & 26 \\
\hline $\begin{array}{l}\text { Scrap depleted uranium to recovery (mixed with } \\
\text { plutonium), } \mathrm{kg} \mathrm{HM}\end{array}$ & & . & & & 100 & & 400 & 133 & & 500 \\
\hline Waste plutoniumf (mixed with depleted uranium), $\mathrm{kg} \mathrm{HM}$ & & & & & 1.25 & & 6 & 2 & & 7 \\
\hline Waste depleted uranium (mixed with plutonium), $\mathrm{kg} \mathrm{HM}$ & & & & & 25 & & 100 & 33 & & 125 \\
\hline \multicolumn{11}{|l|}{ Waste volumes } \\
\hline Volume of TRU waste generated, $8 \mathrm{~m}^{3}$ & & & & & 10 & & 120 & 40 & 0.2 & 130 \\
\hline Volume of LLW generated, $\mathrm{m}^{3}$ & & & & 10 & 10 & & 120 & 40 & 0.2 & 140 \\
\hline Volume of mixed LLW generated, $\mathrm{m}^{3}$ & & & & 0.4 & 0.4 & & 3 & 1 & & 4 \\
\hline Volume of liquid LLW generated, L & & & & 40,000 & 40,000 & & 480,000 & 160,000 & 800 & 560,000 \\
\hline Volume of liquid TRU generated, $\mathrm{L}$ & & & & & 50 & & 600 & 200 & 1 & 650 \\
\hline Volume of nonhazardous solid, $\mathrm{m}^{3}$ & & & & 650 & 650 & & 3,900 & 1,300 & & 5,200 \\
\hline Volume of nonhazardous sanitary liquid, L & & & & 800,000 & 800,000 & & $4,800,000$ & $1,600,000$ & & $6,400,000$ \\
\hline
\end{tabular}

a In the event LEU rods are used in place of MOX rods in the assembly, the amount of plutonium processed in the LA fuel fabrication facility will be reduced accordingly, as will the amount of waste generated.

${ }^{b}$ Assumed that pellets in rejected rods can be reused.

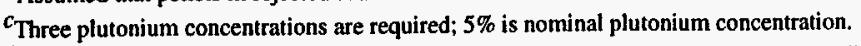

dTotal uranium and plutonium scrap will be sent to the immobilization alternative for disposition.

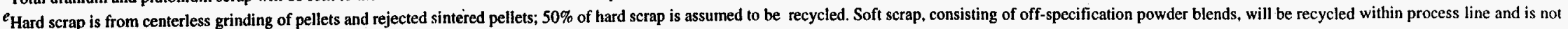
considered in this table.

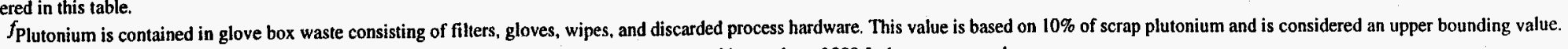

${ }^{8}$ The volume of TRU waste includes mixed TRU waste: solid waste volumes were estimated in number of $200-\mathrm{L}$ drums generated. 
ORNL-DWG 97-2856 EFG

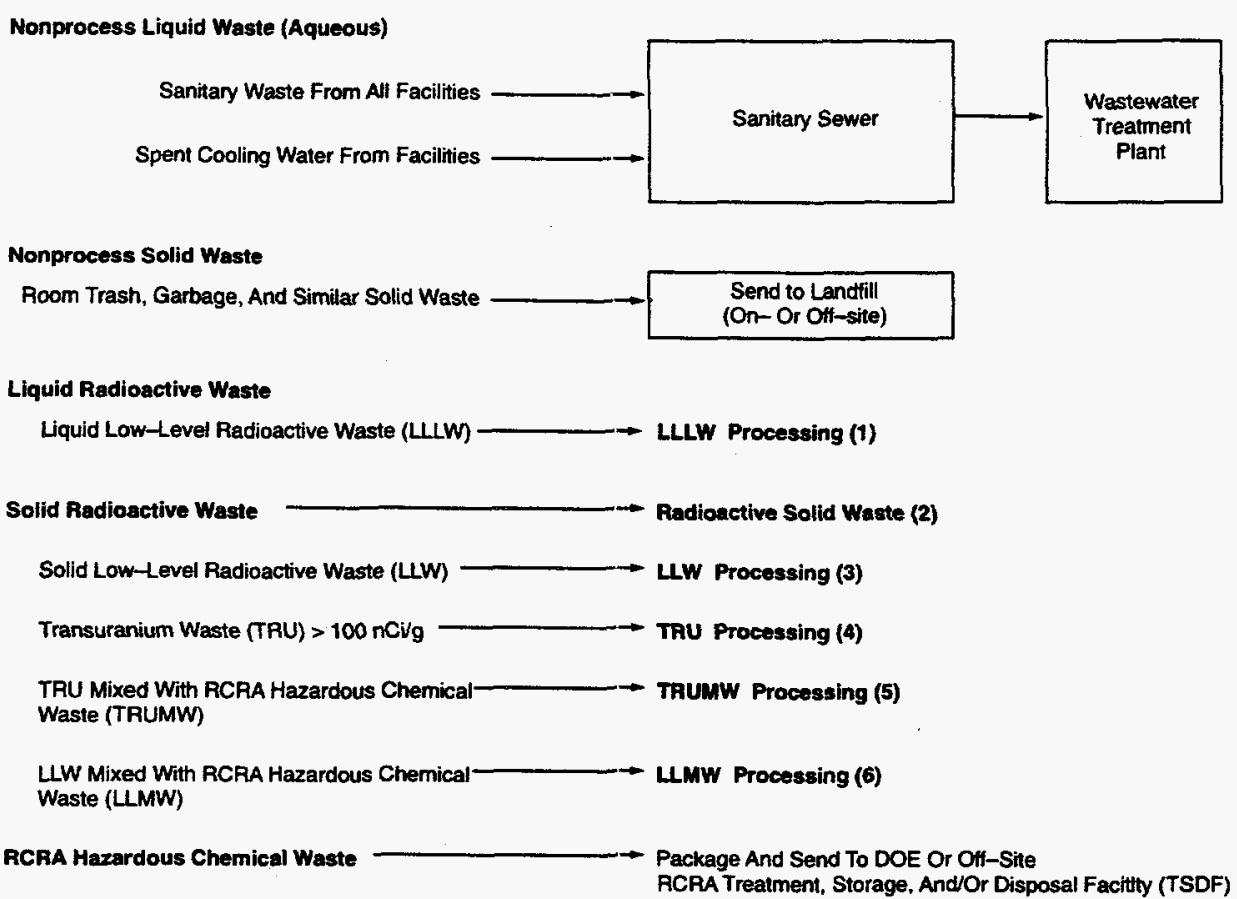

Fig. 8(a). Waste generated during LA MOX fuel fabrication facility operation. 
1. LLLW Processing

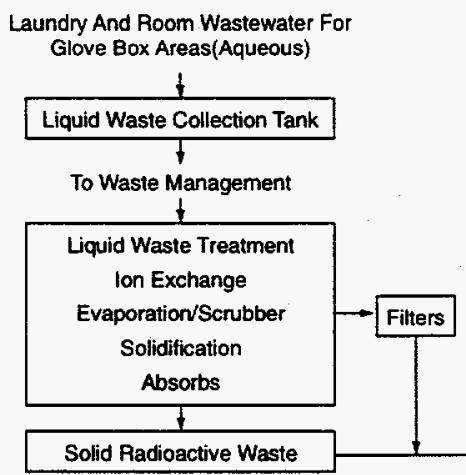

3. LLW Processing

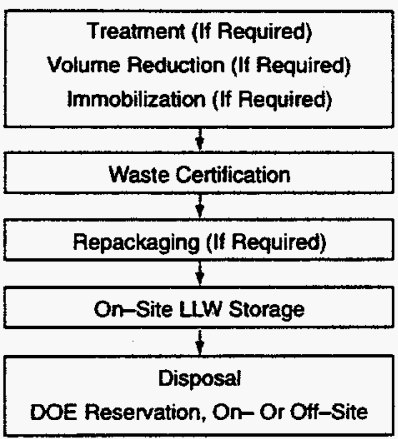

6. LLMW Processing

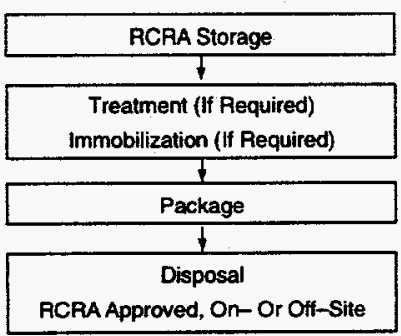

\section{Solid Radioactive Waste}

Glove Box And Some Room Waste

\begin{tabular}{|c|c|}
\hline Segregation By Generator & Hazardous Mixed Waste \\
\hline Compactable & 1 \\
\hline Noncompactable & Collection By Generator \\
\hline Special Case Waste & $t$ \\
\hline 1 & Packaging By Generator \\
\hline Collection By Generator & 1 \\
\hline$t$ & Certification By Generator \\
\hline Packaging By Generator & 1 \\
\hline 1 & RCRA 90-d Storage \\
\hline Certification By Generator & \\
\hline To Waste Management & To Waste Management \\
\hline$t$ & 1 \\
\hline $\begin{array}{c}\text { Nondestructive Assay } \\
<100 \mathrm{nCi} / \mathrm{g} \text { To LLW Processing } \\
>100 \mathrm{nCi} / \mathrm{g} \text { To TAU Processing }\end{array}$ & $\begin{array}{c}\text { Nondestructive Assay } \\
<100 \mathrm{nCi} / \mathrm{g} \text { To LMWW Processing } \\
>100 \mathrm{nCi} / \mathrm{g} \text { To TRUMW Processing }\end{array}$ \\
\hline
\end{tabular}

4. TRU Solid Waste $>100$ nCVg Processing

5. TRUMW Processing

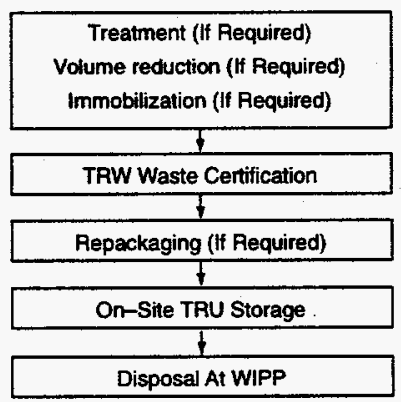

Fig. 8(b). Waste generated during LA MOX fuel fabrication facility operation. 
Page Intentionally Blank 


\section{RESOURCE NEEDS}

\subsection{CONSTRUCTION RESOURCE NEEDS}

Category I Approach. Data for resource needs during construction for the Category I facility approach are estimated from the input to the Plutonium Immobilization-Ceramic Option in Existing SRS Facilities EIS data call, which has been adjusted for the size and type of the proposed project.

Non-Category I Approach. Data for resource needs during construction for the non-Category I facility approach are estimated as a fraction of the Category I facility data based on the smaller scale modification required and the scattered locations.

\subsubsection{Annual Utility Consumption}

Category I Approach. The following utilities will be used: $2,800 \mathrm{MWh}$ of electricity, $1.0 \mathrm{MW}(\mathrm{e})$ for peak electrical load (PEL), and 4,000,000 gal of water.

Non-Category I Approach. The following utilities will be used: 1,200 MWh of electricity, $1.0 \mathrm{MW}(\mathrm{e})$ for PEL, and 1,000,000 gal of water.

\subsubsection{Chemicals}

None or negligible amounts of chemicals will be used during construction for both the Category I and non-Category I approaches.

\subsubsection{Materials and Resources Consumed}

Category I Approach. The following materials will be consumed: $25 \mathrm{yd}^{3}$ of concrete, 50 tons of steel, 2,000 $\mathrm{ft}^{3}$ of industrial gases, and 12,000 gal of fuel.

Non-Category I Approach. The following materials will be consumed: $5 \mathrm{yd}^{3}$ of concrete, 5 tons of steel, $1000 \mathrm{ft}^{3}$ of industrial gases, and $8000 \mathrm{gal}$ of fuel.

\subsection{OPERATIONAL RESOURCE NEEDS}

The initial scaling factor for resource requirements for the LA fabrication facility is based on a linear measure derived from the capacity of the MOX fuel fabrication facility. The annual quantity of surplus plutonium [3.5 metric tons (MT) plutonium (4.0 $\left.\mathrm{MT} \mathrm{PuO}_{2}\right)$ ] and the MOX fuel fabrication facility requirements were obtained from the LANL Response to the Surplus Plutonium Disposition Environmental Impact Statement Data Call for a Mixed Oxide Fuel Fabrication Facility Located at the Pantex Plant. ${ }^{2}$ The annual quantity requirement for uranium [88 MT HM (100 MT UO $\left.\mathrm{UO}_{2}\right)$ ] was obtained from the Initial Data Report and Response to the Surplus Plutonium Disposition Environmental Impact Statement Data Call for the $\mathrm{UO}_{2}$ Supply. ${ }^{3}$

The annual plutonium and uranium capacity requirements and the scaling factors are calculated as follows:

1. LA fabrication facility plutonium capacity

Plutonium required for production $=250 \mathrm{~kg} \mathrm{HM}$ plutonium

Plutonium required including rejection rate of $20 \%=250 \mathrm{~kg} \mathrm{HM}$ plutonium $\times 120 \%=300 \mathrm{~kg} \mathrm{HM}$ plutonium ( $50 \mathrm{~kg} \mathrm{HM}$ to be recycled)

Annualized plutonium requirements $=(300 \mathrm{~kg} \mathrm{HM}$ plutonium $) / 3$ years $=100 \mathrm{~kg} \mathrm{HM}$ plutonium

Annualized MT HM plutonium capacity $=(100 \mathrm{~kg} \mathrm{HM}$ plutonium $) /(1000 \mathrm{~kg} / \mathrm{MT})=0.1 \mathrm{MT} \mathrm{HM}$ plutonium

2. LA fabrication facility uranium capacity

Uranium required for production $=5000 \mathrm{~kg} \mathrm{HM}$ uranium 
Uranium required including rejection rate of $20 \%=5000 \mathrm{~kg} \mathrm{HM}$ uranium $\times 120 \%=6000 \mathrm{~kg} \mathrm{HM}$ uranium ( $1000 \mathrm{~kg} \mathrm{HM}$ to be recycled)

Annualized uranium requirements $=(6000 \mathrm{~kg} \mathrm{HM}$ uranium $) / 3$ years $=2000 \mathrm{~kg} \mathrm{HM}$ uranium

Annualized MT HM uranium capacity $=(2000 \mathrm{~kg}$ HM uranium $) /(1000 \mathrm{~kg} / \mathrm{MT})=2.0 \mathrm{MT} \mathrm{HM}$ uranium

3. LA fabrication facility capacity

Annual LA capacity $=(0.1$ plutonium +2.0 uranium $) \mathrm{MT} \mathrm{HM}=2.1 \mathrm{MT}$ HM MOX

Annual mission surplus plutonium $=3.5 \mathrm{MT}$ HM plutonium

Annual uranium requirements for mission MOX at 5\% plutonium $=66.5 \mathrm{MT}$ HM uranium

Annual MOX production $=(3.5$ plutonium +66.5 uranium $)$ MT HM MOX $=70 \mathrm{MT}$ HM MOX

4. Scaling factor $=(2.1 / 70)$ MT HM MOX $=0.03 \%=3 \%$

This report assumes that $3 \%$ of the MOX fuel fabrication facility requirements is the initial base requirement of the LA fabrication facility. Resource requirements and contingencies in addition to $3 \%$ are noted separately for each resource. In situations where requirement scaling is not applicable, full calculations of resource requirements are provided. Resources needed for the LA fabrication facility are summarized in Table 6. (In the event LEU rods are used in place of some MOX rods, the resource needs will be reduced proportionately.)

\subsubsection{Utilities}

Utility connections at the sites being considered for the LA fabrication facility are currently installed and in use. For analysis purposes, it is not anticipated that additional connections will be required. Utility requirements beyond those necessary for maintenance of the building's present usage are based on those for the MOX fuel fabrication facility, scaled to $3 \%$, and then increased by a $200 \%$ contingency factor for bounding purposes. The original MOX requirements were developed from the NRC environmental report for the Westinghouse Recycle Fuels Plant (see Ref. 2, Appendix A) with a 200-MT MOX fabrication capacity. The annual requirements are calculated as

$$
24,000 \mathrm{MWh} \times(100 \mathrm{MT} / 200 \mathrm{MT}) \times 3 \% \times 200 \%=720 \mathrm{MWh} .
$$

The peak demand is based the MOX fabrication facility's peak demand of $<5 \mathrm{MW}(\mathrm{e})$ and is calculated as

$$
<5 \mathrm{MW}(\mathrm{e}) \times 1000 \mathrm{~kW}(\mathrm{e}) / \mathrm{MW}(\mathrm{e}) \times 3 \% \times 200 \%<300 \mathrm{~kW}(\mathrm{e})
$$

\subsubsection{Fuel Resources}

Fuel resource requirements for the LA fabrication facility are site dependent. Based on the MOX fabrication facility's generic fuel needs, it is assumed that the LA fabrication facility will require natural gas or coal for heating and electricity for sintering. Oil products or gasoline will be necessary for operation of two small generators and a small fleet of motorized vehicles.

From Ref. 2, natural gas requirements for heating are calculated as

$920,000 \mathrm{~m}^{3} /$ year $\times 3 \% \times 200 \%$ contingency $=55,200 \mathrm{~m}^{3} /$ year

$$
\times 35.315 \mathrm{ft}^{3} / \mathrm{MT}=1,949,388 \mathrm{ft}^{3} / \text { year } \approx 1,950,000 \mathrm{ft}^{3} / \text { year } .
$$

Equivalent coal requirements using Kentucky-grade coal at $14,000 \mathrm{Btu} / \mathrm{ft}^{3}$ are

$$
\left(1,950,000 \mathrm{ft}^{3} \times 900 \mathrm{Btu} / \mathrm{ft}^{3}\right) /\left(14,000 \mathrm{Btu} / \mathrm{ft}^{3} \times 1 \mathrm{~T} / 2000 \mathrm{lb}\right)=62.68 \mathrm{~T} \equiv 60 \mathrm{MT}
$$

SRS will use coal for heating. 
Table 6. Resource needs during operation of the LA fabrication facility

\begin{tabular}{|c|c|}
\hline Resource requirement & Annual average consumption \\
\hline \multicolumn{2}{|l|}{ Utilities } \\
\hline Electricity & $720 \mathrm{MWh}$ \\
\hline Peak demand & $<300 \mathrm{~kW}(\mathrm{e})$ \\
\hline \multicolumn{2}{|l|}{ Fuel } \\
\hline Coal (for heating) & $60 \mathrm{MT}(66 \mathrm{~T})$ \\
\hline Diesel fuel (for generator) & $4,600 \mathrm{~L}(1,215 \mathrm{gal})$ \\
\hline Gasoline (for vehicles) & $6,900 \mathrm{~L}(1,825 \mathrm{gal})$ \\
\hline \multicolumn{2}{|l|}{ Water } \\
\hline Groundwater & $1,600,000 \mathrm{~L}(411,000 \mathrm{gal})$ \\
\hline Peak demand & No peak requirements anticipated \\
\hline Surface water & None required for this process \\
\hline \multicolumn{2}{|l|}{ Process chemicals and compounds ${ }^{a}$} \\
\hline \multicolumn{2}{|l|}{ Gases } \\
\hline Argon & $16,000 \mathrm{~m}^{3}\left(565,000 \mathrm{ft}^{3}\right)$ \\
\hline Helium & $10 \mathrm{~m}^{3}\left(350 \mathrm{ft}^{3}\right)$ \\
\hline Hydrogen & $1,000 \mathrm{~m}^{3}\left(35,500 \mathrm{ft}^{3}\right)$ \\
\hline Nitrogen & $5,300 \mathrm{~m}^{3}\left(187,000 \mathrm{ft}^{3}\right)$ \\
\hline Oxygen & $5,000 \mathrm{~m}^{3}\left(174,000 \mathrm{ft}^{3}\right)$ \\
\hline \multicolumn{2}{|l|}{ Liquids } \\
\hline Hydrochloric acid (HCl) & $0.5 \mathrm{~kg}(1 \mathrm{lb})$ \\
\hline Nitric acid $\left(\mathrm{HNO}_{3}\right)$ & $1 \mathrm{~kg}(2 \mathrm{lb})$ \\
\hline Polyethylene glycol & $20 \mathrm{~kg}(<45 \mathrm{lb})$ \\
\hline Sulfuric acid $\left(\mathrm{H}_{2} \mathrm{SO}_{4}\right)$ & $2 \mathrm{~kg}(5 \mathrm{lb})$ \\
\hline \multicolumn{2}{|l|}{ Solids, kg (lb) } \\
\hline Sodium hydroxide $(\mathrm{NaOH})$ & 16 kg (34 lb) \\
\hline Sodium nitrate $\left(\mathrm{NaNO}_{3}\right)$ & $85 \mathrm{~kg}(<200 \mathrm{lb})$ \\
\hline Zinc stearate & $20 \mathrm{~kg}(<45 \mathrm{lb})$ \\
\hline \multicolumn{2}{|l|}{ Nonprocess chemicals } \\
\hline \multicolumn{2}{|l|}{ Liquids } \\
\hline Alcohol & $225 \mathrm{~L}(60 \mathrm{gal})$ \\
\hline Hydraulic fluid & $4.5 \mathrm{~kg}(10 \mathrm{lb})$ \\
\hline General cleaning fluids & $225 \mathrm{~L}(60 \mathrm{gal})$ \\
\hline \multicolumn{2}{|l|}{ Radioactive process materials } \\
\hline \multicolumn{2}{|l|}{ Plutonium dioxide $\left(\mathrm{PuO}_{2}\right)$} \\
\hline Hot startup & $23.6 \mathrm{~kg}(52 \mathrm{lb})$ \\
\hline Annually for 3 years & $113.5 \mathrm{~kg}(250 \mathrm{lb})$ \\
\hline \multicolumn{2}{|l|}{ Uranium dioxide $\left(\mathrm{UO}_{2}\right)$} \\
\hline Cold startup & $510 \mathrm{~kg}(1,125 \mathrm{lb})$ \\
\hline Hot startup & $475 \mathrm{~kg}(1,045 \mathrm{lb})$ \\
\hline Annually for 3 years & $2,270 \mathrm{~kg}(5,000 \mathrm{lb})$ \\
\hline
\end{tabular}
inventory. 
Oil products in the form of diesel fuel are required for operation of emergency generators. Based on technical specifications and testing requirements for generator operability, ${ }^{4}$ each of two generators will operate $30 \mathrm{~h} /$ year. Testing is required for $1 \mathrm{~h}$ each month for verification of operation, $1 \mathrm{~h}$ twice a year for full-load and manual synchronization, and $24 \mathrm{~h}$ every 18 months to confirm capability for continuous operation. Assuming that peak capacity is $300 \mathrm{~kW}(\mathrm{e})$ and that approximately $50 \%$ of peak demand should be available for glove box ventilation, emergency lighting, and other required electrical support, two $150-\mathrm{kW}$ capacity generators will be necessary at the LA fabrication facility. Based on a consumption rate of $38 \mathrm{~L} / \mathrm{h}(10 \mathrm{gal} / \mathrm{h})$, requirements for oil products are calculated as follows:

$38 \mathrm{~L} / \mathrm{h} \times 30 \mathrm{~h} /$ year $\times 2$ generators $\times 200 \%$ contingency $=4560 \mathrm{~L} /$ year $\cong 4600 \mathrm{~L} /$ year.

Because of the facility size and the potential distances between areas being used to support the LA mission, a distance of up to 2.5 miles $(4 \mathrm{~km})$ between the LA fabrication facility and other areas is assumed. An estimate of gasoline required for operation of motorized vehicle usage is based on requirements of 5 miles round-trip for 10 trips daily at $\sim 0.38 \mathrm{~L} / \mathrm{mile}(0.1 \mathrm{gal} / \mathrm{mile})$. The standard days of operation are calculated in Sect. 5.1 as $365 \mathrm{~d} /$ year. The fuel consumption for motorized vehicles at the LA fabrication facility is estimated as

$$
10 \mathrm{trips} / \mathrm{d} \times 5 \mathrm{miles} / \text { trip } \times 0.38 \mathrm{~L} / \text { mile } \times 355 \mathrm{~d} / \text { year }=6935 \mathrm{~L} / \text { year } \equiv 6900 \mathrm{~L} / \text { year } .
$$

The total requirement for oil products is $-11,500 \mathrm{~L} /$ year $(3,040 \mathrm{gal} / \mathrm{year})$.

\subsubsection{Water}

Based on the MOX fuel fabrication facility's water requirement of $25 \mathrm{gal} / \mathrm{d}(95 \mathrm{~L} / \mathrm{d})$ per employee, 24 employees working $250 \mathrm{~d}$ at the LA fabrication facility on the first shift, and 12 employees performing shift work for $365 \mathrm{~d}$, the annual sanitary water resource usage is calculated as

$(25 \mathrm{gal} / \mathrm{d}) \times[(24$ employees $\times 250 \mathrm{~d} /$ year $)+(12$ employees $\times 365 \mathrm{~d} / \mathrm{year} \times 2 \mathrm{shifts})$

$$
+(12 \text { employees } \times 115 \mathrm{~d} / \text { year })]=403,500 \mathrm{gal} / \mathrm{year} \text {, }
$$

where calculations of the number of employees are in Sect. 5.1.

Nonsanitary water requirements are based on scaling the MOX fuel fabrication facility ${ }^{2}$ with a 100-MT capacity to $10 \%$ of requirements. The $10 \%$ factor was used in lieu of $3 \%$ based on the nonlinear requirements for staffing between the MOX fuel fabrication facility and the LA fabrication facility. The usage is calculated as follows:

$$
191 \mathrm{gal} / \mathrm{d} \times 10 \% \times(365 \mathrm{~d} / \mathrm{year})=6972 \mathrm{gal} / \mathrm{year} .
$$

Total groundwater usage is rounded to 411,000 gal/year $(1,600,000$ L/year $)$.

\subsubsection{Process and Nonprocess Chemicals and Compounds}

Process and nonprocess chemicals in gas, liquid, and solid form will be required in the operation of the LA fabrication facility. Those chemicals required in significant quantities are identified in Table 6. Most of the chemicals required will be available from existing site inventory. 
It is assumed that the sintering furnace will have a purge rate of $30 \mathrm{~L} / \mathrm{min}$, requiring $\sim 94 \%$ argon and $6 \%$ hydrogen for operations. This number is derived as a function of the purge rates for large production furnaces that are typically on the order of $10 \mathrm{ft}^{3} / \mathrm{min}$. Assuming that the sintering furnace for the LA program will require one-tenth of the typical purge rate, a rate of $1 \mathrm{ft}^{3} / \mathrm{min}$ would be reasonable. There are $28.3 \mathrm{~L} / \mathrm{ft}^{3}$, which rounds up to $30 \mathrm{~L} / \mathrm{ft}^{3}$, resulting in a $30-\mathrm{L} /$ min purge rate.

Because of requirement calculations for some chemicals resulting in minimal quantities, the amounts required have been rounded upward for bounding purposes. The quantities of process and nonprocess chemicals required in quantifiable amounts were calculated based on projected uses and requirements that follow.

Alcohol: for process and nonprocess cleaning purposes

$5 \mathrm{gal} / \mathrm{month} \times 12 \mathrm{months} /$ year $=60 \mathrm{gal} /$ year

Argon: required for sintering furnaces

$(30 \mathrm{~L} / \mathrm{min}) \times(525,600 \mathrm{~min} /$ year $) \times 0.001 \mathrm{~m}^{3} / \mathrm{L}=15,768 \mathrm{~m}^{3} /$ year $\cong 16,000 \mathrm{~m}^{3} /$ year

General cleaning fluids: for nonprocess cleaning purposes

$5 \mathrm{gal} /$ month $\times 12$ months $/$ year $=60 \mathrm{gal} /$ year

Helium: required as process gas

$0.2 \mathrm{~m}^{3} /$ week $\times 52$ weeks $/$ year $=10 \mathrm{~m}^{3} /$ year

Hydraulic fluid: lubricant

$0.2 \mathrm{lb} /$ week $\times 52$ weeks/year $\cong 10 \mathrm{lb} /$ year

Hydrochloric acid: required in service laboratory

$5 \mathrm{lb} \times 20 \%=1 \mathrm{lb} /$ year

Hydrogen: required in sintering furnaces

$(30 \mathrm{~L} / \mathrm{min}) \times(525,600 \mathrm{~min} /$ year $) \times 0.001 \mathrm{~m}^{3} / \mathrm{L} \times 6 \%=946 \mathrm{~m}^{3} /$ year $\cong 1000 \mathrm{~m}^{3} /$ year

Nitric acid: required in service laboratory

$8 \mathrm{lb} \times 20 \%=1.6 \mathrm{lb} /$ year $\equiv 2 \mathrm{lb} /$ year

Nitrogen: required in glove boxes

$(1 \mathrm{~L} / \mathrm{min}) \times(525,600 \mathrm{~min} /$ year $) \times 0.001 \mathrm{~m}^{3} / \mathrm{L} \times 10$ glove boxes $=5256 \mathrm{~m}^{3} /$ year $\cong 5300 \mathrm{~m}^{3} /$ year

Oxygen: required for dry recycle process-assume $580 \mathrm{~h} /$ year dry recycle processing

$\left(5 \mathrm{ft}^{3} \mathrm{O}_{2} / \mathrm{min}\right) \times(60 \mathrm{~min} / \mathrm{h}) \times(680 \mathrm{~h} /$ year $)=\left(174,000 \mathrm{fl}^{3} \mathrm{O}_{2} /\right.$ year $) \cong 4927 \mathrm{~m}^{3} \cong 5000 \mathrm{~m}^{3} \mathrm{O}_{2} /$ year

Polyethylene glycol: required in blending process

$700 \mathrm{lb} \times 3 \% \times 200 \%=44 \mathrm{lb} /$ year $\cong 45 \mathrm{lb} /$ year

Sodium hydroxide: required in laboratory scrubber $170 \mathrm{lb} \times 20 \%=34 \mathrm{lb} /$ year

Sodium nitrate: required in laboratory scrubber $3100 \mathrm{lb} \times 3 \% \times 200 \% \cong 186 \mathrm{lb} /$ year $\cong 200 \mathrm{lb} /$ year

Sulfuric acid: required in service laboratory $17 \mathrm{lb} \times 20 \%=3.4 \mathrm{lb} /$ year $\cong 5 \mathrm{lb} /$ year

Zinc stearate: required in pellet pressing process $670 \mathrm{lb} \times 3 \% \times 200 \%=40.2 \mathrm{lb} /$ year $\cong 45 \mathrm{lb} /$ year 


\subsubsection{Radioactive Process Materials}

The radioactive process materials used at the $\mathrm{LA}$ fabrication facility are $\mathrm{PuO}_{2}$ and $\mathrm{UO}_{2}$. Based on the bounding case of $100 \mathrm{~g}$ plutonium per rod, 264 rods per assembly (full MOX), 5\% plutonium for rods, and 10 full-MOX assemblies produced over a 3-year period, $113.5 \mathrm{~kg}(250 \mathrm{lb})$ of $\mathrm{PuO}_{2}$ and $2270 \mathrm{~kg}(5000 \mathrm{lb})$ $\mathrm{UO}_{2}$ would be required annually. The calculations are provided in Sects. 4.2.5.1 and 4.2.5.2.

\subsubsection{Plutonium requirements}

The conversion factor for plutonium to $\mathrm{PuO}_{2}=(\mathrm{mol} w \mathrm{PuO}) /(\mathrm{mol}$ wt plutonium $)=271.0 /$ $239.0=1.1339$.

Plutonium required for 3-year LA mission $=250 \mathrm{~kg} \mathrm{HM}$ plutonium (Table 5)

Annual plutonium with rejection rate of $20 \%=250 \mathrm{~kg} \mathrm{HM}$ plutonium $\times 120 \% / 3$ years

$$
=100 \mathrm{~kg} \mathrm{HM} \text { plutonium/year }
$$

$100 \mathrm{~kg} \mathrm{HM}$ plutonium $\times 1.1339=113.39 \mathrm{~kg} \mathrm{PuO} 2 \cong 113.5 \mathrm{~kg} \mathrm{PuO}_{2} /$ year

The plutonium requirements for hot startup operations are

$$
(250 \mathrm{~kg} \mathrm{HM} \text { plutonium }) /(3 \text { years }) \times 25 \% \times 1.1339=23.6 \mathrm{~kg} \mathrm{PuO} 2
$$

Total plutonium requirements for the LA fabrication facility for the 3-year mission are $364 \mathrm{~kg} \mathrm{PuO}_{2}$.

\subsubsection{Uranium requirements}

The conversion factor for uranium to $\mathrm{UO}_{2}=\mathrm{mol} \mathrm{wt} \mathrm{UO}_{2} / \mathrm{mol} \mathrm{wt}$ uranium $=270.03 / 238.03=1.1344$.

Uranium required for 3-year LA mission $=5000 \mathrm{~kg}$ HM uranium (Table 5)

Annual uranium with rejection rate of $20 \%=5000 \mathrm{~kg} \mathrm{HM}$ uranium $\times 120 \% / 3$ years

$$
=2000 \mathrm{~kg} \mathrm{HM} \text { uranium/year }
$$

$2000 \mathrm{~kg} \mathrm{HM}$ uranium $\times 1.1344=2268.8 \mathrm{~kg} \mathrm{UO} \cong 2270 \mathrm{~kg} \mathrm{UO} 2 /$ year

The uranium requirements for cold and hot startup operations during the first year of production follow.

Hot: $(5000 \mathrm{~kg} \mathrm{HM}$ uranium $) /(3$ years $) \times 25 \% \times 1.1344=472.67 \mathrm{~kg} \mathrm{UO} \cong 475 \mathrm{~kg} \mathrm{UO} 2$

Cold: $(5000 \mathrm{~kg} \mathrm{HM}$ uranium $) /(3$ years $) \times 27 \% \times 1.1344=510.49 \mathrm{~kg} \mathrm{UO_{2 }} \cong 510 \mathrm{~kg} \mathrm{UO} 2$

Total uranium requirements for the LA fabrication facility for the 3-year mission are slightly less than $7,800 \mathrm{~kg}(17,200 \mathrm{lb}) \mathrm{UO}_{2}$. 


\section{EMPLOYMENT REQUIREMENTS}

\subsection{ANNUAL EMPLOYMENT REQUIREMENTS DURING OPERATION OF THE LA FABRICATION FACILITY}

Table 7 provides the annual number of employees by labor category, the number of shifts, the number of employees per shift, and the number of operating days per year for the LA fabrication facility. It is assumed that the facility will operate continuously with the primary work effort during standard business days of operation at the selected site. The standard days of operation were calculated as follows:

$$
(365 \mathrm{~d} / \text { year })-[(104 \text { weekend days })+(11 \text { holidays })]=250 \mathrm{~d} / \text { year } .
$$

The 11 holidays considered are New Year's Day, Martin Luther King Day, Good Friday, Memorial Day, Independence Day (2 days), Labor Day, Thanksgiving ( 2 days), and Christmas ( 2 days).

The number of employees in Table 7 was derived from a reduction in personnel required for the MOX fuel fabrication facility with consideration given for the nature of operations necessary to maintain 24-h performance. ${ }^{2}$ Twenty-four employees will be required on the standard operation shift. Twelve additional employees will be required on each of three alternate shifts, resulting in total staffing needs of 60 employees.

Many of these positions probably will be filled by existing employees at the site. This estimate is generic in nature, and some of the sites under consideration may require fewer employees based on existing infrastructure. For example, facilities with on-site plutonium processing facilities may require only a nominal increase in support personnel and management. Industrial support organizations (such as site superintendent, site security, emergency response, health services, and personnel support) and atmospheric and groundwater monitoring will be provided by the site operator because these facilities are currently being serviced by the site.

Based on the estimates for the MOX fuel fabrication facility, a personnel requirement was established if more than $80 \%$ effort of a full-time equivalent (FTE) was charged out to support the LA fabrication facility operation. ${ }^{2}$ Those efforts requiring less than $80 \%$ of an FTE were considered part of operations of the existing site. The assumptions used in consideration of staffing levels for the LA fabrication facility are given in Table 8.

Table 7. Annual employment requirements during operation of the LA fabrication facility

\begin{tabular}{lcc}
\hline Labor category $a$ & $\begin{array}{c}\text { Number of } \\
\text { employees on one } \\
\text { shift of } 250 \mathrm{~d} / \text { year }\end{array}$ & $\begin{array}{c}\text { Number of employees on } \\
\text { each of three alternate } \\
\text { shifts of } 365 \mathrm{~d} / \text { year }^{b}\end{array}$ \\
\hline Officials and managers & 1 & 0 \\
Professionals & 4 & 0 \\
Technicians & 10 & 7 \\
Office and clerical & 2 & 0 \\
Craft workers (skilled) & 2 & 1 \\
Operatives (semiskilled) & 2 & 2 \\
Service workers & $\frac{2}{12}$ \\
\hline Total & $\frac{3}{24}$ & 12 \\
\hline
\end{tabular}

${ }^{a}$ All fractional manpower requirements are rounded up to whole numbers.

${ }^{b}$ Two $365 \mathrm{~d} /$ year shifts and one $115 \mathrm{~d}$ /year shift. 
Table 8. Assumptions used in consideration of staffing levels for the LA fabrication facility

1. The facility will be built on an existing DOE site with a minimum of $4500 \mathrm{ft}^{2}$ available space ( $3000 \mathrm{ft}^{2}$ for MOX rod processing, $1000 \mathrm{ft}^{2}$ for bundling activities, and $500 \mathrm{ft}^{2}$ for fuel bundle storage).

2. The site will have an existing infrastructure in place to accept the LA mission.

3. Personnel will be required to support a process capacity of $\sim 2 \mathrm{MT}$ HM per year.

4. Personnel involved in SNM operations must work in pairs and follow specific safety precautions detailed by the site.

5. Personnel must attend required site training. A staffing requirement for training purposes has been included in this estimate.

6. Space will be allocated for SSTs carrying plutorium and transportation for uranium so that loading can be accomplished on a follow-up operating shift if the transport arrives near or following the close of standard business.

7. As with the MOX fuel fabrication facility estimate, the staffing requirements assume that $\sim 20 \%$ of the employee's time will be taken through training, vacation, personal leave, or illness. Even though employees cannot necessarily transition from one position to another, a contingency was added to account for nonproductive time.

\subsection{RADIATION DOSES (WHOLE BODY) TO INVOLVED WORKERS DURING MODIFICATION OF THE LA FABRICATION FACILITY}

\subsubsection{Employment During Construction of the Category I Approach}

Table 9 shows the estimated employment during the proposed modification of the USF facility as a demonstration MOX fuel LA fabrication facility. The construction phase of the proposed modification is estimated to require 24 months.

The proposed project will upgrade existing USF facility in the $221-\mathrm{H}$ Canyon building. The USF facility has not been operated and is not expected to have additional radioactive impact to workers and the public during construction.

\section{Radiological Impact to Employees}

During previous fuel processing in the H-Canyon facility, the maximum individual worker exposure was estimated at $0.04 \mathrm{rem} / \mathrm{year}$, and the average worker exposure was estimated at $0.01 \mathrm{rem} / \mathrm{year}$.

Table 9. Estimated construction employment for the Category I approach

\begin{tabular}{clccc}
\hline Year & Labor category & $\begin{array}{c}\text { Number of } \\
\text { shifts }\end{array}$ & $\begin{array}{c}\text { Number of } \\
\text { workers } \\
\text { per shift }\end{array}$ & $\begin{array}{c}\text { Number of } \\
\text { workdays } \\
\text { per year }\end{array}$ \\
\hline $1 \quad$ & Skilled workers & 2 & 50 & 240 \\
& Administrative & 2 & 3 & 240 \\
& Management & 2 & 8 & 240 \\
& Total (shifts $\times$ workers/shift) & & 122 & \\
2 & Skilled workers & 2 & 50 & 240 \\
& Administrative & 2 & 3 & 240 \\
& Management & 2 & 8 & 240 \\
& Total (shifts $\times$ workers/shift) & & 122 & \\
\hline
\end{tabular}




\subsubsection{Employment During Construction of the Non-Category I Approach}

Table 10 shows the estimated construction employment during the proposed modification of the facilities for use as a non-Category I demonstration MOX fuel LA fabrication facility. It is assumed that the construction phase of the proposed modification will require a schedule of 12 months.

The proposed project will modify existing glove boxes in the SRTC C-Wing process room and in the 200-F Area Canyon Building fifth level FB-Line Mechanical Line, and installation of new equipment for bundle assembly in the $\mathrm{H}$-Canyon building. The FB-Line is assumed to have the highest radioactivity relative to the other two locations, and thus is used for estimating additional radioactive impact (if any) to workers and the public during construction.

\section{Radiological Impact to Employees}

During previous fuel processing in the FB-Line facility, the maximum individual worker exposure was estimated at $0.44 \mathrm{rem} / \mathrm{year}$ and the average worker exposure was estimated at $0.14 \mathrm{rem} / \mathrm{year}$. Additionally, $\mathrm{H}$-Canyon maximum exposure $0.04 \mathrm{rem} / \mathrm{year}$ and average $0.01 \mathrm{rem} / \mathrm{year}$; and SRTC maximum $0.08 \mathrm{rem} / \mathrm{year}$, average $0.06 \mathrm{rem} / \mathrm{year}$.

\subsection{RADIATION DOSES (WHOLE BODY) TO INVOLVED WORKERS DURING OPERATION OF THE LA FABRICATION FACILITY}

The provided dose estimates to workers are based on those found in 10 Code of Federal Regulations (CFR) 835 and the administrative control level (ACL) found in DOE N 441.1. Fissile material processing for the LA program will be conducted at a DOE site and should be subject to DOE N 441.1, a DOE notice that establishes a maximum allowable dose of $2 \mathrm{rem} /$ year (see Table 11). ALARA will be the goal in all operations. The primary hazard in the LA program will be processing $\mathrm{PuO}_{2}$ powder and the possibility of inhalation of the $\mathrm{PuO}_{2}$ dust.

Estimated dose to radiation workers for handling 3013 cans during $\mathrm{PuO}_{2}$ powder homogenization operations and blending with $\mathrm{UO}_{2}$ powder will be below the $\mathrm{ACL}$ found in DOE N 441.1.

Table 10. Estimated construction employment for the non-Category I approach

\begin{tabular}{clccc}
\hline Year & Labor category & $\begin{array}{c}\text { Number of } \\
\text { shifts }\end{array}$ & $\begin{array}{c}\text { Number of } \\
\text { workers per shift }\end{array}$ & $\begin{array}{c}\text { Number of workdays } \\
\text { per year }\end{array}$ \\
\hline 1 & Skilled workers & 2 & 40 & 240 \\
& Administrative & 2 & 2 & 240 \\
& Management & 2 & 6 & 240 \\
& Total (shifts $\times$ workers/shift) & & 96 & \\
\hline
\end{tabular}

Table 11. Radiation doses (whole body) to involved workers during operation of the LA fabrication facility

\begin{tabular}{lr}
\hline $\begin{array}{l}\text { Average maximum target annual dose to all involved workers at the } \\
\text { facility, mrem }\end{array}$ & 500 \\
Maximum allowable administrative dose limit, mrem & 2000 \\
Total number of involved workers & 55 \\
\hline
\end{tabular}


Page Intentionally Blank 


\section{WASTES, EMISSIONS, AND EXPOSURES}

\subsection{WASTES GENERATED DURING FACILITY MODIFICATION}

Category I Approach. The solid and liquid wastes generated during construction include the equipment previously installed, concrete and steel construction waste materials, and sanitary wastewater. The steel construction waste material will be recycled as scrap material before construction is completed. No radioactive or mixed wastes are expected during modification because no radioactive material was introduced to the facility. The total quantities of solid and liquid waste generated during construction are shown in Table 12.

Non-Category I Approach. The solid and liquid wastes generated during construction include the previously installed equipment, concrete and steel construction waste materials, and sanitary wastewater. The steel construction waste material will be recycled as scrap material before completing construction. Some radioactive solid waste (contaminated equipment) is expected during modification of the glove boxes in the SRTC process area and the FB-Line mechanical line. It is assumed that some items will be decontaminated and packaged as solid LLW while others will be packaged as TRU waste. These wastes will be stored at the site until a waste repository is available. No radioactive liquid waste is expected. The total quantities of solid and liquid wastes generated during the non-Category I facility modification are shown in Table 13.

Table 12. Total wastes generated during construction for the Category I approach

\begin{tabular}{|c|c|}
\hline Waste category & Quantity \\
\hline Construction debris & $50 \mathrm{yd}^{3}$ \\
\hline Steel & 100 tons \\
\hline Sanitary waste water & $\begin{array}{l}1,250,000 \mathrm{gal} \\
\text { (at } 25 \mathrm{gpd} / \text { worker) }\end{array}$ \\
\hline Hazardous waste ${ }^{a}$ & $2 \mathrm{yd}^{3}$ \\
\hline
\end{tabular}

$a_{\text {Batteries, fluorescent light tubes, etc., and liquid }}$ wastes (lube oils, hydraulic fluids, and cleaning solvents).

Table 13. Total wastes generated during construction for the non-Category I approach

\begin{tabular}{ll}
\hline \multicolumn{1}{c}{ Waste category } & \multicolumn{1}{c}{ Quantity } \\
\hline Construction debris & $20 \mathrm{yd}^{3}$ \\
Steel & 5 tons \\
Sanitary waste water & $700,000 \mathrm{gal}$ \\
TRU waste & $5 \mathrm{yd}^{3}$ \\
Low-level solid waste & $10 \mathrm{yd}^{3}$ \\
Hazardous waste & $a$ \\
\hline
\end{tabular}

$a_{\text {Batteries, fluorescent light tubes, etc., }}$ and liquid wastes (lube oils, hydraulic fluids, and cleaning solvents). 


\subsubsection{Emissions During Construction}

Category I Approach. Minimum emission of air pollutants is expected during construction because the majority of construction work is performed inside the USF in the 221-H Canyon Building. The principal sources of such emissions are fugitive dust, exhaust from construction equipment and vehicles that deliver materials and carry construction workers. The estimated annual emissions generated during construction are shown in Table 14.

Non-Category I Approach. Minimum emission of air pollutants is expected during construction because the majority of construction work is performed inside the facilities in the SRTC, FB-Line, and the $\mathrm{H}$-Canyon buildings. The principal sources of such emissions are fugitive dust, exhaust from construction equipment and vehicles that deliver materials and carry construction workers. The estimated annual emissions generated during construction are shown in Table 14.

Table 14. Emissions during peak construction year

\begin{tabular}{lc}
\hline \multicolumn{1}{c}{ Chemical } & $\begin{array}{c}\text { Emission } \\
\text { (ton) }\end{array}$ \\
\hline Sulfur dioxide & 0.01 \\
Oxides of nitrogen & 0.08 \\
Volatile organic compounds (VOCs) & 0.02 \\
Carbon monoxide & 0.40 \\
Particulate matter (10 $\mu$ m or smaller) & 0.01 \\
Total suspended particulates & 0.02 \\
\hline
\end{tabular}

\subsubsection{Effluents During Construction}

Category I Approach. Because all construction activities will be performed in existing facilities, no additional effluents are generated from the proposed project during modification of the USF inside the 221-H Canyon Building.

Non-Category I Approach. Because all construction activities will be performed in existing facilities, no additional effluents will be generated from the proposed project during modification of the nonCategory I facility at SRS.

\subsubsection{Radiological Impact During Construction}

Category I Approach. The proposed project will upgrade the existing USF in 221-H Canyon Building. The USF has not been operated and is not expected to have additional radioactive impact to workers and the public during construction.

Non-Category I Approach. The proposed project will modify existing glove boxes in the SRTC C-Wing process room and in the 200-F Area Canyon Building fifth-level FB-Line mechanical line. New equipment will be installed for bundle assembly and storage in the H-Canyon building. The FB-Line is assumed to have the highest radioactivity relative to the other two locations; thus, it is used for estimating additional radioactive impact (if any) to workers and the public during construction.

\subsubsection{Radiological Impact to Employees}

Category I Approach. During previous fuel processing in the H-Canyon facility, the maximum individual worker exposure was estimated at $0.04 \mathrm{rem} / \mathrm{year}$; and the average worker exposure was estimated at $0.01 \mathrm{rem} / \mathrm{year}$. 
Non-Category I Approach. During previous fuel processing in the FB-Line facility, the maximum individual worker exposure was estimated at $0.44 \mathrm{rem} / \mathrm{year}$, and the average worker exposure was estimated at $0.14 \mathrm{rem} /$ year.

\subsubsection{Radiological Impact to the Public}

Category I Approach. Construction activities are performed in a clean facility inside the 221- $\mathrm{H}$ Canyon Building. No additional radiological impact to the public at the site boundary is expected during the construction phase of the proposed project.

Non-Category I Approach. Construction activities are performed in facilities inside existing buildings with containment and regulated ventilation systems. No additional radiological impact to the public at the site boundary is expected during the construction phase of the proposed project.

\subsection{WASTES GENERATED DURING OPERATION OF THE FACILITY}

Table 15 provides the annual volume, total estimated volume, description, and anticipated treatment method by waste category for liquids and solids anticipated during operation of the LA fabrication facility. Only very small quantities of chemical emissions are anticipated from analytical operations resulting from sampling.

A total of $0.4 \mathrm{mg} /$ year of plutonium is estimated to be released to the air during the operation of the LA MOX facility. This plutonium release corresponds to a total activity of $94 \mu \mathrm{Ci} /$ year. The total plutonium release includes two contributions; $0.3 \mathrm{mg} /$ year is expected to be released during normal operation of the plant and an additional $0.1 \mathrm{mg} / \mathrm{year}$ during a one-time abnormal event (spilling the powder of one $3013 \mathrm{can}$ ).

The release during normal operation has been estimated from the releases reported in Ref. 2 for a 100-MT HM/year MOX plant with two lines. Reference 2 reports a release of $0.6 \mathrm{mg} / \mathrm{year}$ of plutonium. The LA MOX facility has only one line and a smaller capacity (about 2.5 MT HM/year). For conservatism, one-half of the releases of the large MOX plant (with two lines) has been estimated for the small LA MOX facility (with only one line); therefore, the value is $0.3 \mathrm{mg} / \mathrm{year}$. No scaling consideration has been given to the much smaller capacity of the LA MOX facility (about 1/40 of the large MOX plant).

The release during the abnormal event has been calculated by dropping one 3013 can containing $4.5 \mathrm{~kg}$ of plutonium. From Ref. 5 (Table 4-13) the following factors were selected:

- ARF (airborne release fraction) $=3.3 \times 10^{-3}$

- $\mathrm{RF}$ (respirable factor) $=0.62$

Also, the efficiency of the HEPA filters in the glove box has been assumed to be $99.9 \%$ (equivalent to a release factor of $10^{-3}$ ) and the efficiency of the building HEPA filters as $99 \%$ (equivalent to a release factor of $10^{-2}$ ). Overall, the air emission for this event is

$$
4500 \mathrm{~g} \times 3.3 \times 10^{-3} \times 0.62 \times 10^{-3} \times 10^{-2}=0.092 \mathrm{mg} / \text { year } \cong 0.1 \mathrm{mg} / \text { year } .
$$

Air emissions will result from the burning of coal for building heat, but no more than would be expected if this activity did not occupy buildings on the SRS. 
Table 15. Estimated waste generated during operation of the LA fabrication facility $a$

\begin{tabular}{|c|c|c|c|c|c|c|c|}
\hline \multirow{2}{*}{$\begin{array}{l}\text { Waste } \\
\text { category }\end{array}$} & \multicolumn{2}{|c|}{ Annual volume } & \multicolumn{2}{|c|}{ Total volume } & \multirow{2}{*}{$\begin{array}{c}\text { Waste } \\
\text { description }\end{array}$} & \multirow{2}{*}{$\begin{array}{l}\text { Anticipated } \\
\text { treatment }\end{array}$} & \multirow{2}{*}{$\begin{array}{l}\text { Disposal } \\
\text { method }\end{array}$} \\
\hline & $\left(\mathrm{m}^{3}\right.$ or $\left.\mathrm{L}\right)$ & $\left(\mathrm{ft}^{3}\right.$ or gal) & $\left(m^{3}\right.$ or $\left.L\right)$ & $\left(\mathrm{ft}^{3}\right.$ or gal) & & & \\
\hline TRU-solid $\left(\mathrm{m}^{3}\right.$ or $\left.\mathrm{ft}^{3}\right)$ & 40 & 1,413 & 130 & 4,591 & $\begin{array}{l}\text { Glove box gloves } \\
\text { Bag-in plastic } \\
\text { Empty bottles } \\
\text { Filters } \\
\text { Scrapped equipment items } \\
\text { Furnace hardware } \\
\text { Wipes } \\
\text { Metal cans } \\
\text { Metallography waste }\end{array}$ & Compaction & $\begin{array}{l}\text { Off-site at Waste Isolation Pilot } \\
\text { Plant (WIPP) }\end{array}$ \\
\hline TRU-mixed $\left(\mathrm{m}^{3} \text { or } \mathrm{ft}^{3}\right)^{b}$ & $<1$ & $<35$ & $<1$ & $<35$ & $\begin{array}{l}\text { Organics from sintering } \\
\text { Sludges from liquids } \\
\text { Analytical waste }\end{array}$ & $\begin{array}{l}\text { From liquid treatment } \\
\text { absorption to TRU solid }\end{array}$ & Off-site at WIPP \\
\hline TRU-liquids ( $\mathrm{L}$ or gal) & 200 & 53 & 650 & 172 & $\begin{array}{l}\text { Sludges from liquids } \\
\text { Analytical waste } \\
\text { Metallography waste }\end{array}$ & $\begin{array}{l}\text { Absorption to TRU solid } \\
\text { or liquid LLW }\end{array}$ & As solid off-site at WIPP \\
\hline$L L W-$ solid $\left(m^{3}\right.$ or $\left.\mathrm{ft}^{3}\right)$ & 40 & 1,413 & 140 & 4,944 & $\begin{array}{l}\text { Room trash } \\
\text { Biotter paper } \\
\text { Wipes } \\
\text { Mop heads } \\
\text { Gloves/shoe covers } \\
\text { Solidified sludges } \\
\text { lon exchange resins } \\
\text { Discarded C-clothing } \\
\text { Metal cans and rods }\end{array}$ & $\begin{array}{l}\text { Incineration } \\
\text { Compaction } \\
\text { Solidification } \\
\text { Metal melting }\end{array}$ & DOE on- or off-site disposal \\
\hline LLW-mixed (L or gal) & 1 & 0.3 & 4 & 1.1 & $\begin{array}{l}\text { Solvents from cleaning } \\
\text { Analytical waste } \\
\text { Sludges from liquids }\end{array}$ & $\begin{array}{l}\text { Incineration } \\
\text { Solidification }\end{array}$ & $\begin{array}{l}\text { RCRA-approved disposal } \\
\text { DOE on- or off-site } \\
\text { Commercial off-site }\end{array}$ \\
\hline LLW-liquid (L or gal) & 160,000 & 42,267 & 560,000 & 147,935 & $\begin{array}{l}\text { Decontaminated wastewater } \\
\text { Laundry wastewater } \\
\text { Analytical wastewater }\end{array}$ & $\begin{array}{l}\text { Ion exchange } \\
\text { Evaporation/ } \\
\text { scrubber } \\
\text { Solidification }\end{array}$ & $\begin{array}{l}\text { Evaporation } \\
\text { NPDES }{ }^{c} \text { permitted discharge }\end{array}$ \\
\hline Hazardous (L or gal) & 1.5 & 0.4 & 4 & & Process ends & Recycle & \\
\hline Nonhazardous-liquid (L or gal) & $1,600,000$ & 411,000 & $6,400,000$ & $1,644,000$ & Sewage waste & Sewage treatment & NPDES permitted discharge \\
\hline
\end{tabular}

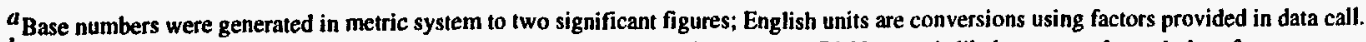

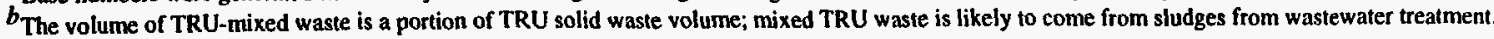

$c_{\text {NPDES }}=$ National Pollutant Discharge Elimination System.

Note: Estimates are based on historical experience from other programs and current programs. 


\section{ACCIDENT ANALYSIS}

\subsection{INTRODUCTION}

The LA fabrication process represents a very small scale process replication of the large 100-MT/year MOX fuel fabrication facility. The LA assembly fabrication will likely take place in an existing building complex. The process is envisioned to consist of a number (10-20) of glove boxes along with several hoppers, a press, a furnace, and a rod/bundle assembly area. The process can be done in a single large room, but it may also be done using several rooms (or buildings) with the material at the end stage of certain steps involving transportation and/or storage at another building. A generalized approach was taken because these specifics were unknown. Section 7.2 describes the accident analysis approach and mitigating design features that are assumed to be available. Section 7.3 describes the events that were selected for EIS evaluation and the estimated source terms that were chosen for all sites. These source terms are characterized here as "evaluation basis" because the facilities already exist and may have other design basis accidents that may or may not be similar to these accidents. Chemical source terms for the facility are discussed in Sect. 7.4. Site-specific aspects are discussed in Sect. 7.5.

\subsection{GENERAL APPROACH AND GENERIC DESIGN ASSUMPTIONS}

\subsubsection{Accident Analysis Approach}

In Ref. 2, a preliminary hazards analysis (PHA) was referenced for a 100-MT/year MOX fuel fabrication plant. This analysis identified 32 accidents which resulted from a variety of events. Specific events for the design-basis and beyond-design basis accidents were then selected from the hazard analysis to be further analyzed in the EIS. In that analysis, four design basis accidents and two beyond-design basis accidents were selected.

Several accident scenarios can be postulated for processing facilities, and many do not result in a source term that leaves the building. The objective of this accident analysis is to examine the frequency and estimated source terms of several events that are expected to result in a significant release from the building. Ventilation system design assumptions such as the use of HEPA filters that affect the leak-path factor are discussed in the next section. Using the methodology in Ref. 5, source terms are derived based on the combination of the material at risk, damage ratio, release fractions, respirable fractions, and the building leak-path factor.

The many unknowns and options associated with the LA fabrication plant did not warrant the performance of a building-/process-specific PHA for the LA facility. Currently, several different proposed fuel fabrication processes are combined with five sites. Knowledge concerning the PHA in Ref. 2 was combined with a knowledge of what the LA plant would generally be expected to look like. These aspects, along with a conservative estimate of the expected material flows of the plant, were used to select conservative accident source terms for the LA EIS analysis. Even though the scale of the LA plant is much smaller, it is thought that the LA facility will have many of the same accident initiators. Selected accident scenarios and the materials at risk were combined with bounding airborne release fractions and respirable fractions from DOE HDBK-3010-94 (Ref. 5) to derive conservative source terms.

With respect to estimated frequencies, the same approach that was taken in Ref. 2 is used. Frequency categories of anticipated $\left(10^{-1}\right.$ /year to $10^{-2} /$ year), unlikely $\left(10^{-2} /\right.$ year to $10^{-4} /$ year $)$, extremely unlikely $\left(10^{-4} /\right.$ year to $10^{-6} /$ year $)$, and beyond the evaluation basis $\left(<10^{-6} /\right.$ year for most events) were usually assigned in this assessment.

No attempt was made to quantify all of the site-specific features that affect the accident analysis. Rather, a generic set (six events are evaluated) of source term magnitudes was used at each site. This set of source terms was derived based on a specified plant process and some general assumptions regarding facility mitigators. No claim is made that the accident source terms cited here bound or are bounded by the existing site-specific analysis. Some site specifics such as stack heights and seismic frequencies were deemed to be a necessary input. The site-specific characteristics used for this site are discussed in Sect. 7.5. 
The generic facility design assumptions that are made which are not site-specific are discussed in Sect. 7.2.2.

\subsubsection{Facility Design Assumptions}

\subsubsection{Plutonium isotopics and MOX fuel}

The isotopic compositions of the plutonium and various MOX blends are shown in Table 16. With respect to both the master mix and fuel blend, the aranium dominates (a minimum of $90 \%$ ) the weight percent of the mix. However, the radiological contribution of the low specific activities of the uranium isotopes ( -5 orders of magnitude) are so low (as compared to the plutonium isotopes) that they are ignored in the calculation of the source terms. In the event LEU rods are used in place of some MOX rods, the radiological contribution from the LEU rods will also be very low compared to the plutonium contribution. Therefore, the accident analyses only consider full MOX assemblies. The respective isotopic activities for the plutonium oxide powder and the MOX powder (conservatively assuming $10 \%$ enrichment) or fuel are shown in this table. For each accident scenario, the appropriate $\left(\mathrm{PuO}_{2}\right.$, master mix, or fuel blend) isotopic ratios are applied to the quantities at risk to determine the material at risk. This number is then multiplied by the leak-path factor, damage ratio, airborne release fraction, and respirable fraction to determine the released source terms. The leak-path factor incorporates the assumption as to whether the release is filtered.

\subsubsection{Ventilation system}

A complete description of site-specific existing facility ventilation system specifics is beyond the scope of this section. However, in many process buildings, ventilation flows are maintained such that fresh air is taken through the cleanest radiological areas (such as adjacent offices) first. The air flow path is then drawn through the rooms where radiological work is performed. Most facility systems are designed such that glove boxes in these rooms are run at pressures lower than the room pressure to limit the spread of contamination in the event of glove box failure. Contamination would be drawn in to the glove box filter to limit contamination in the room. The exact facility specifics and credit for mitigating design features involved in accident situations will vary, depending on the facility selected and any facility modifications needed to support the LA mission. The intent of this section is to clearly describe the mitigators associated with the ventilation system that are credited in this analysis.

Table 16. Specific activities for process powders (source of isotopics-Ref. 2)

\begin{tabular}{lrcccc}
\hline Isotope $^{a}$ & $\begin{array}{c}\text { Weight } \\
\text { percent }\end{array}$ & $\begin{array}{c}\text { Specific activity } \\
(\mathrm{Ci} / \mathrm{g})^{b}\end{array}$ & $\begin{array}{c}\text { Activity in } \\
\mathrm{PuO}_{2} \text { mix } \\
(\mathrm{Ci} / \mathrm{g} \mathrm{mix})^{c}\end{array}$ & $\begin{array}{c}\text { Activity in 30\% } \mathrm{PuO}_{2} \\
\text { enriched } \\
(\mathrm{Ci} / \mathrm{g} \mathrm{mix})^{d}\end{array}$ & $\begin{array}{c}\text { Activity in 10\% } \mathrm{PuO}_{2} \\
\text { enriched MOX mix } \\
(\mathrm{Ci} / \mathrm{g} \mathrm{mix})^{d}\end{array}$ \\
\hline${ }^{238} \mathrm{Pu}$ & 0.03 & $1.712 \times 10^{1}$ & $4.530 \times 10^{-3}$ & $1.359 \times 10^{-3}$ & $4.530 \times 10^{-4}$ \\
${ }^{239} \mathrm{Pu}$ & 92.44 & $6.204 \times 10^{-2}$ & $5.045 \times 10^{-2}$ & $1.514 \times 10^{-2}$ & $5.045 \times 10^{-3}$ \\
${ }^{240} \mathrm{Pu}$ & 6.47 & $2.270 \times 10^{-1}$ & $1.293 \times 10^{-2}$ & $3.879 \times 10^{-3}$ & $1.293 \times 10^{-3}$ \\
${ }^{241} \mathrm{Pu}$ & 0.05 & $1.030 \times 10^{2}$ & $4.542 \times 10^{-2}$ & $1.363 \times 10^{-2}$ & $4.542 \times 10^{-3}$ \\
${ }^{242} \mathrm{Pu}$ & 0.10 & $3.926 \times 10^{-3}$ & $3.463 \times 10^{-6}$ & $1.039 \times 10^{-6}$ & $3.463 \times 10^{-7}$ \\
${ }^{241} \mathrm{Am}$ & 0.90 & $3.428 \times 10^{0}$ & $2.721 \times 10^{-3}$ & $8.163 \times 10^{-3}$ & $2.721 \times 10^{-3}$ \\
\hline
\end{tabular}

$a_{\text {The activity of }}{ }^{235} \mathrm{U}$ and ${ }^{238} \mathrm{U}$ are ignored for all mixes because of their low specific activities as compared tc the plutonium isotopes.

${ }^{b}$ Specific activities are taken from Table of Radioactive Isotopes by Browne and Firestone. ${ }^{6}$

$c_{\text {Based on }} \mathrm{PuO}_{2}$ mix being $88.2 \%$ plutonium by weight.

$d_{30 \%}$ is master mix; $10 \%$ is a conservative estimate for fuel blend. 
Generally, a number of filters and prefilters would exist in the release path for a typical processing building that supports plutonium processing. Usually one or more filters are at the ventilation outlet of the glove box. These filters are generally accessible in the room where the glove box is located. However, no credit in source term reduction was taken for these filters in this analysis. This approach was taken because arguments could be made that the events in question jeopardize the integrity of nearby filters. For the EIS purposes, this approach was deemed appropriate. However, this does not mean that in the safety analysis (which would be performed after the building has been selected) of various glove box designs, credit could never be taken for those (or other) filters. The decision of what equipment will be qualified (and credit assumed for in the various events) will be made during the subsequent safety review of the facility (e.g., after facility selection). This decision is beyond the scope of this EIS analysis because many facility specific aspects are not known at this stage of the analysis.

The glove box system may be served by a dedicated ventilation system that often ties into the overall system upstream of a series of HEPA filters. With respect to the analysis of events in which overall building confinement is maintained, credit (for the source term reduction) is taken for two serial HEPA filters that generally lie outside the building confinement. The efficiency is assumed to be $99.9 \%$ for the first filter. A HEPA filter at the factory is rated at $99.97 \%$, but when installed may test to $99.95 \%$. The facility may run with this for a while and allow some degradation in performance during the operating period. Thus, in practice, a 99.9\% efficiency is judged to be appropriate for this filter (roughing filters and prefilters are ignored). A reduced efficiency of $99.0 \%$ is used for the second filter (resulting in a combined leak-path factor of $1 \times 10^{-5}$ ). These filters are considered in this analysis where confinement is assumed to be intact and to provide significant source term reduction.

\subsubsection{Process flows}

Table 17 shows the process inventories and material flows used for the accident analysis. The average plutonium enrichment is nominally taken to be $5 \%$ for the fuel. However, because some fuel blends could go higher, an upper bound of $10 \%$ plutonium enrichment was selected. Table 17 was generally constructed on that basis. A $30 \%$ master mix blend was also selected. Table 17 was not intended to rigidly define the fuel fabrication material process because a number of candidate processes (with different material balances) may be used in the facility. Because the purpose of this table is to provide materials at risk, a conservative estimate of the maximum amount of material at a process station or in interim storage at a certain location was made.

It is important to remember that with respect to assumed process flows, no more than $32 \mathrm{~kg}$ of plutonium oxide is ever assumed to be in the process line between the plutonium oxide vessel and the fuel rod loading step. As a result, no more than $32 \mathrm{~kg}$ of plutonium oxide (which is about $28 \mathrm{~kg}$ of pure plutonium) would be at risk in the process line, except for events that involve the vault (which is involved in beyond-evaluation basis events). The $32 \mathrm{~kg}$ of oxide does not include the two cans containing $5 \mathrm{~kg}$ of pure plutonium oxide that are assumed to be in process between the vault and the oxide loading vessel. Thus, a total of $42 \mathrm{~kg}$ of oxide in powder form has been considered in this analysis. Finished fuel rods are not considered because they are generally nondispersible as compared to powder. No effort has been made to model site-specific process flows and distinguish corresponding risk differences because there are so many process and facility unknowns at present. Rather, a generic (but thought to be generally conservative) process flow assumption has been made for all sites. Site-specific differences considered in the analysis are discussed in Sect. 7.5.

For most, if not all accident scenarios, materials at risk will be subjected to orders of magnitude multipliers in the calculation to determine the released source term. Thus, a high level of accuracy is not warranted at this stage of the analysis. Table 17 was used in combination with Ref. 5 and knowledge of the accident dynamics to obtain the source terms for the LA fabrication facility. In each accident scenario, a material at risk assumption is made at each station, depending on the event and energetics. Table 17 also lists the barriers to release that would be found inside the glove box. Generally, those materials that are inside interim storage cans were considered to be the most vulnerable to dispersion.

It is assumed that large amounts of $\mathrm{PuO}_{2}$ powder would be safely stored in appropriate containers? inside a vault or existing storage location. Considerable credit is taken for this vault (and/or the plutonium oxide containers), and it is assumed that the entire plutonium material feed requirement is in the vault at the 
Table 17. Estimated maximum station inventories for LA fabrication plant ${ }^{a}$

\begin{tabular}{|c|c|c|c|c|}
\hline Location/material station & $\begin{array}{l}\text { Quantity } \\
\text { (g) }\end{array}$ & $\mathrm{PuO}_{2}$ or $\mathrm{MOX}$ & Physical form & $\begin{array}{l}\text { Barriers to release } \\
\text { (to the room) }\end{array}$ \\
\hline Plutonium storage vault & 400,000 & $\mathrm{PuO}_{2}$ & Fine powder & Storage cans/vault \\
\hline $\begin{array}{l}\text { Plutonium oxide ( } 2 \text { cans in } \\
\text { process) }\end{array}$ & 10,000 & $\mathrm{PuO}_{2}$ & Fine powder & $3013 \mathrm{can}^{7}$ \\
\hline $\begin{array}{l}\text { Plutonium oxide loading } \\
\text { vessel }\end{array}$ & 16,000 & $\mathrm{PuO}_{2}$ & Fine powder & Steel vessel/glove box \\
\hline Master mix vessel & 53,000 & MOX ( $30 \%$ blend) & Fine powder & Steel vessel/glove box \\
\hline Master mix powder storage & 107,000 & MOX (30\% blend) & Fine powder & $\begin{array}{l}\text { Interim storage } \\
\text { cans/glove box }\end{array}$ \\
\hline V-blender & 40,000 & $\operatorname{MOX}(10 \%$ blend $)$ & Fine powder & $\begin{array}{l}\text { Rotating steel } \\
\text { vessel/glove box }\end{array}$ \\
\hline MOX blend storage & 320,000 & MOX (10\% blend) & Fine powder & $\begin{array}{l}\text { Interim storage } \\
\text { cans/glove box }\end{array}$ \\
\hline MOX granulation area & 10,000 & MOX ( $10 \%$ blend) & $\begin{array}{l}\text { Pressed/very } \\
\text { coarse powder }\end{array}$ & Machinery/glove box \\
\hline MOX pellet press & 1,000 & MOX (10\% blend) & $\begin{array}{l}\text { Pressed to } 0.6 \\
\text { theoretical } \\
\text { density (TD) }\end{array}$ & $\begin{array}{l}\text { Inside of press/glove } \\
\text { box }\end{array}$ \\
\hline $\begin{array}{l}\text { MOX green pellet storage (in } \\
\text { pellet press area) }\end{array}$ & 80,000 & MOX (10\% blend $)$ & $\begin{array}{l}\text { Pressed to } 0.6 \\
\text { TD }\end{array}$ & $\begin{array}{l}\text { Interim storage } \\
\text { cans/glove box }\end{array}$ \\
\hline Pellet sintering furnace & 40,000 & MOX (10\% blend) & $\begin{array}{l}\text { Green and } \\
\text { sintered }\end{array}$ & $\begin{array}{l}\text { Inside furnace/glove } \\
\text { box }\end{array}$ \\
\hline Sintered pellet storage & 160,000 & MOX ( $10 \%$ blend) & Sintered pellets & $\begin{array}{l}\text { Interim storage } \\
\text { cans/glove box }\end{array}$ \\
\hline $\begin{array}{l}\text { Pellet grinding area/ground } \\
\text { sintered pellets }\end{array}$ & 10,000 & MOX (10\% blend) & $\begin{array}{l}\text { Grindings of } \\
\text { sintered pellets }\end{array}$ & Containers/glove box \\
\hline $\begin{array}{l}\text { Pellet grinding area/dust } \\
\text { control area }\end{array}$ & 100 & MOX ( $10 \%$ blend) & Fine powder & Loose dust/glove box \\
\hline Pellet inspection & 4,000 & MOX (10\% blend) & Finished pellets & Trays/glove box \\
\hline $\begin{array}{l}\text { Fuel rod loading, inspection, } \\
\text { and storage }\end{array}$ & 20,000 & MOX ( $10 \%$ blend) & Finished pellets & $\begin{array}{l}\text { About ten rods if } \\
\text { cladded }\end{array}$ \\
\hline $\begin{array}{l}\text { Bundle assembly and storage } \\
\text { (end of fabrication) }\end{array}$ & $7,200,000$ & $\begin{array}{l}\text { MOX ( } 5 \% \text { average } \\
\text { blend) }\end{array}$ & Finished pellets & $\begin{array}{l}\text { Cladded in ten } \\
\text { bundles }\end{array}$ \\
\hline Scrap recovery area & 10,000 & $\mathrm{MOX}$ and $\mathrm{PuO}_{2}$ & $\begin{array}{l}\text { Mostly green and } \\
\text { sintered pellets }\end{array}$ & Few dispersibles \\
\hline
\end{tabular}

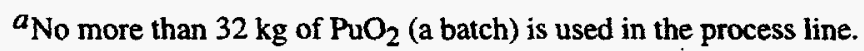

Source: Ref. 7

start of the mission. It was conservatively assumed that $400 \mathrm{~kg}$ of oxide powder is in the vault at the start of the process. This inventory is held in 80 cans, each of which holds $5 \mathrm{~kg}$ of oxide powder (4.4 $\mathrm{kg}$ of plutonium).

The overall layout of the facility is such that from 10-20 glove boxes are accommodated. The equipment is considered to be located in the same room, and generally, little credit is taken for segregation of the processes. Little credit is also taken for the glove boxes. The glove boxes are generally assumed to fail in the postulated events. This may or may not accurately portray the process line once it is designed (because glove boxes with a robust design may b used). However, this approach is thought to be conservative. 
Finished fuel assemblies and clad rods were considered in this analysis but are thought to be generally nondispersible. Accidents that involve this inventory are thought to be bounded by the accidents involving the vault and the other in-process steps where dispersible powders are involved.

\subsection{SELECTED EVENTS FOR THE LA EIS ANALYSIS}

\subsubsection{Criticality Event}

\subsubsection{Discussion}

The prevention of criticality events is a major goal of the criticality safety program and is an important part of the overall conduct of operations for the facility. Within the nuclear processing industry, such prevention programs have successfully reduced the number of inadvertent criticalities over the years. The goal of the criticality safety program is to attempt (as much as is reasonably possible) to make the possibility of a criticality less than credible (generally accepted to be $<1 \times 10^{-6}$ /year frequency). Reference 8 establishes the DOE's nuclear criticality safety program requirements. Similarly, NRC also requires a criticality safety program, and those requirements are assumed to be implemented at the LA fabrication facility.

The risk impact associated with an inadvertent criticality event is highest with respect to workers located in the immediate vicinity (health impacts up to and including death could occur from prompt gamma and neutron doses). Collocated workers and the public would be affected to a lesser degree. The major dose pathways for these impacts are likely to be cloud shine (noble gases) and inhalation (mostly associated with the radioiodines).

With respect to the LA fabrication plant, criticalities could be postulated in several areas (i.e., powder storage, the glove boxes involved in mixing, the furnace, and possibly the fuel rod storage area). The estimated frequencies associated with these events will vary depending on the controls in place, the number of operator movements, and the amount of fissile material present. A generic approach was taken with respect to the selection of the specifics of this event rather than selecting a criticality scenario associated with a specific operation in the LA fabrication.

\subsubsection{Source term}

The significant quantities of fissile materials in LA necessitate consideration of a criticality event. Because a limited number of rods are being made, a criticality event associated with a large array of fuel rods was not selected for this event. Because sources of moderation may be assumed to be either accidentally or inadvertently introduced into the glove boxes/equipment, the limiting fission yield for the facility was based on a scenario for a moderated powder or moderated solid criticality. In Ref. 9 (p. 6-24) dry powder and metal criticalities are quoted at a conservative yield of $1 \times 10^{17}$ fissions. A reference yield of $1 \times 10^{18}$ fissions is considered conservative for fully moderated and reflected solids. Therefore, a conservative selection of $1 \times 10^{18}$ fissions was made for the evaluation of this criticality event.

It is acknowledged that a dry criticality could potentially aerosolize surrounding plutonium and generate respirable particles. The amount of aerosolization is expected to be very small, and the presence of multiple filters would be an effective mitigator against the spread of plutonium out of the ventilation system. Thus, no plutonium was assumed to constitute the source term with respect to exposure of the collocated workers and the public that are outside of the building. Other events involving significant plutonium releases are discussed later.

With respect to release fractions associated with the fission products, it would be expected that a powder would have a surface area such that all noncondensible gases (such as the nobles) and all radioiodines would escape. However, if the criticality involved plutonium, which was in a relatively low surface area to volume ratio, the release fraction associated with the noble gases and radioiodines would be considerably less. In consideration of the present unknown specifics associated with this event, it was deemed conservative and appropriate to select the release fractions for both the nobles and the radioiodines as 1.0. Fission product yields from Table 6-9 of Ref. 5 (a plutonium solution of unknown isotopics for a 
reference yield of $1 \times 10^{19}$ fissions) were selected, and consideration of the selected yield of $1 \times 10^{18}$ fissions resulted in scaling the source terms.

The chosen source term specifics for the evaluation basis criticality event are shown in Table 18. As previously discussed, a conservative fission yield (moderated vs dry criticality) was combined with a conservative release fraction (for a powder vs moderated criticality). Thus, the source term in Table 18 is judged to be very conservative. The release height should be selected as the appropriate stack height for the facility where dose consequences are being calculated. The leak-path factor was taken as 1.0.

\subsubsection{Frequency estimate}

Criticalities have occurred considerably less frequently than in the earlier days of nuclear research, development, and operations. A number of these accidents are discussed in Ref. 10. None of these accidents are specifically associated with dry plutonium powder. However, several accidents involving dry metal, moderated metals, and fuel rods have occurred during the last 50 years. The fact that 30-40 criticalities in the United States have historically (mostly in the 1940s, 1950s, and 1960s) occurred suggests that the accident spectrum analyzed for this facility should contain a criticality at a low estimated frequency. As was the case in Ref. 2, a frequency estimate of extremely unlikely $\left(1 \times 10^{-4}\right.$ to $1 \times 10^{-6} /$ year) is still judged to be appropriate for this event. However, the frequency of this event is judged to be somewhat less (perhaps 1 order of magnitude) than that at the large plant (100 MT/year vs $2 \mathrm{MT} / \mathrm{year}$ ) because of the simplicity of the LA plant and the lower amounts of fissile material being handled.

Table 18. Source term for the evaluation basis criticality event (stack release with a relatively short duration)

\begin{tabular}{|c|c|}
\hline Isotope & $\begin{array}{l}\text { Released radioactivity } \\
\text { (Ci) }\end{array}$ \\
\hline $83 \mathrm{~m}_{\mathrm{Kr}}$ & $1.1 \times 10^{1}$ \\
\hline $83 \mathrm{~m}_{\mathrm{Kr}}$ & $7.1 \times 10$ \\
\hline $85 \mathrm{Kr}$ & $8.1 \times 10^{-4}$ \\
\hline${ }^{87} \mathrm{Kr}$ & $4.3 \times 10^{1}$ \\
\hline${ }^{88} \mathrm{Kr}$ & $2.3 \times 10^{1}$ \\
\hline${ }^{89} \mathrm{Kr}$ & $1.3 \times 10^{3}$ \\
\hline $131 \mathrm{~m}_{\mathrm{Xe}}$ & $1.0 \times 10^{-2}$ \\
\hline${ }^{133 m} \mathrm{Xe}$ & $2.2 \times 10^{-1}$ \\
\hline${ }^{133} \mathrm{Xe}$ & $2.7 \times 10$ \\
\hline $135 \mathrm{~m} \times \mathrm{Xe}$ & $3.3 \times 10^{2}$ \\
\hline${ }^{135} \mathrm{Xe}$ & $4.1 \times 10^{1}$ \\
\hline${ }^{137} \mathrm{Xe}$ & $4.9 \times 10^{3}$ \\
\hline${ }^{138} \mathrm{Xe}$ & $1.1 \times 10^{3}$ \\
\hline $131_{I}$ & $1.1 \times 10$ \\
\hline $132 \mathrm{I}$ & $1.2 \times 10^{2}$ \\
\hline${ }^{133} \mathrm{I}$ & $1.6 \times 10^{1}$ \\
\hline${ }_{134}$ I & $4.3 \times 10^{2}$ \\
\hline $135_{I}$ & $4.5 \times 10^{1}$ \\
\hline
\end{tabular}




\subsubsection{Evaluation Basis Seismic Event}

\subsubsection{Discussion}

A seismic event appropriate for the facility's evaluation basis was selected. In this event, major portions of the process line glove boxes are assumed to be breached with the contents available for release. In such an event, the focus was on the dispersible powders that would be at the powder blending stations. The storage vault and receiving area are assumed to have suitable containers for plutonium oxide that will survive an earthquake (3013 cans with double containment). ${ }^{7}$ In-process material in glove boxes is, however, more vulnerable as are powder storage areas that may exist. Finished pellets and fuel rods are thought to be generally nondispersible even though they may escape the glove boxes. In this seismic event, the glove boxes are breached and assumed to fail based on a scenario of falling debris and equipment inside the room. The building confinement and ventilation system are assumed to remain intact, resulting in a filtered stack release.

\subsubsection{Source term}

Because the material in the vault is assumed to be in 3013 cans (which have double containment), no material was judged to be released from this area in this event. Table 19 shows the materials in process along with the release fractions and respirable fractions that were used. The total isotopic source term is shown summarized at the bottom for each plutonium isotope, as is the total amount of plutonium released. Because only $32 \mathrm{~kg}$ of plutonium oxide is allowed in a single batch, it was assumed that this batch was split in inventory between the master mix and fuel blend mix stations. This material was assumed to be in temporary storage cans at their respective stations. Another $10 \mathrm{~kg}$ of plutonium oxide in the form of powder is assumed to be at risk and open within the glove box. This material is from two cans that are taken out of the vault and prepared for loading (no credit for the 3013 can double containment).

In a seismic event, powders in various pieces of equipment will be subjected to many different damage ratios and release fractions. For the pure oxide powder at the feed station, the entire amount was conservatively subjected to a release fraction corresponding to debris falling into powder (no credit for the two open cans, utilizing a $1 \times 10^{-2}$ airborne release fraction and a 0.2 respirable fraction for the total release fraction from Ref. 5). With respect to the $32 \mathrm{~kg}$ batch of in-process powder, the powder stored in interim containers is assumed to be subjected to damage. A $1 \times 10^{-3}$ airborne release fraction and a 0.1 respirable fraction for the total release fraction was selected from Ref. 5 based on falling equipment impacting storage cans of powder. No credit is taken for the glove boxes that were postulated to fail. However, other portions of the process operation were assumed to be resistant to the event because of the material form. Finished pellets and fuel rods were not considered to constitute a significant portion of dispersible material. The source term is assumed to be filtered (leak-path factor of $1 \times 10^{-5}$ ) and released to a stack.

\subsubsection{Frequency estimate}

The frequency estimate for this event varies widely, depending on the site selected (and its respective seismic profile), the building used (and its evaluation basis), and the internal arrangement of equipment (see Sect. 7.5). Generally, a frequency estimate of $1 \times 10^{-2}$ to $1 \times 10^{-4}$ is used for this event (the frequency is usually closer to lower end of this range).

\subsubsection{Evaluation Basis Fire Event}

\subsubsection{Discussion}

A large spectrum of fire events ranging from small fires with no impacts to large multiroom fires with major impacts can be postulated for the LA fabrication building. Unlike the large MOX fabrication facility, the LA mission will take place in an existing building. While many existing buildings within the DOE 
Table 19. Source term for the evaluation basis seismic event

\begin{tabular}{|c|c|c|c|c|c|c|c|c|c|c|c|c|}
\hline $\begin{array}{l}\text { Processing } \\
\text { station }\end{array}$ & $\begin{array}{l}\text { Material at } \\
\text { risk } \\
\text { (g) }\end{array}$ & $\begin{array}{l}\text { Physical } \\
\text { form }\end{array}$ & $\begin{array}{l}\text { Damage } \\
\text { ratio }\end{array}$ & $\begin{array}{l}\text { Airborne } \\
\text { release } \\
\text { fraction }\end{array}$ & $\begin{array}{l}\text { Respirable } \\
\text { fraction }\end{array}$ & $\begin{array}{l}\text { Leak-path } \\
\text { factor }\end{array}$ & $\begin{array}{l}{ }^{238} \mathrm{Pu} \\
\text { released }\end{array}$ & $\begin{array}{l}{ }^{239} \mathrm{Pu} \\
\text { released }\end{array}$ & $\begin{array}{l}{ }^{240} \mathrm{Pu} \\
\text { released }\end{array}$ & $\begin{array}{l}{ }^{241} \mathrm{Pu} \\
\text { released }\end{array}$ & $\begin{array}{l}{ }^{242} \mathrm{Pu} \\
\text { released }\end{array}$ & $\begin{array}{l}{ }^{241} \mathrm{Am} \\
\text { released }\end{array}$ \\
\hline $\begin{array}{l}\text { Plutonium oxide } \\
\text { (2 cans) }\end{array}$ & 10,000 & $\begin{array}{l}\text { Fine powder } \\
\mathrm{PuO}_{2}\end{array}$ & 1.00 & $1.00 \times 10^{-2}$ & 0.20 & $1.00 \times 10^{-5}$ & $9.06 \times 10^{-7}$ & $1.01 \times 10^{-5}$ & $2.59 \times 10^{-6}$ & $0.08 \times 10^{-6}$ & $6.93 \times 10^{-10}$ & $5.44 \times 10^{-6}$ \\
\hline $\begin{array}{l}\text { Master mix } \\
\text { powder storage }\end{array}$ & 53,000 & $\begin{array}{l}\text { Fine powder } \\
\text { MOX ( } 30 \% \\
\text { blend) }\end{array}$ & 1.00 & $1.00 \times 10^{-3}$ & 0.10 & $1.00 \times 10^{-5}$ & $7.20 \times 10^{-8}$ & $8.02 \times 10^{-7}$ & $2.06 \times 10^{-7}$ & $7.22 \times 10^{-7}$ & $5.51 \times 10^{-11}$ & $4.33 \times 10^{-7}$ \\
\hline $\begin{array}{l}\text { MOX blend } \\
\text { storage }\end{array}$ & 160,000 & $\begin{array}{l}\text { Fine powder } \\
\text { MOX (10\% } \\
\text { blend) }\end{array}$ & 1.00 & $1.00 \times 10^{-3}$ & 0.10 & $1.00 \times 10^{-5}$ & $7.25 \times 10^{-8}$ & $8.07 \times 10^{-7}$ & $2.07 \times 10^{-7}$ & $7.27 \times 10^{-7}$ & $5.54 \times 10^{-11}$ & $4.35 \times 10^{-7}$ \\
\hline \multicolumn{7}{|c|}{$\begin{array}{l}\text { Total isotopic source term, Ci } \\
\text { Total source term, Pu/Am mix, g }\end{array}$} & $1.05 \times 10^{-6}$ & $\begin{array}{l}1.17 \times 10^{-5} \\
2.0454 \times 10^{-4}\end{array}$ & $3.00 \times 10^{-6}$ & $1.05 \times 10^{-5}$ & $8.03 \times 10^{-10}$ & $6.31 \times 10^{-6}$ \\
\hline
\end{tabular}


complex are adequately covered by an existing fire protection program, it is reasonable to conclude that existing buildings might be more susceptible to fires (as compared to a new facility where fire protection can be incorporated into the design). However, the existing buildings must still meet the appropriate DOE orders.

A source of combustible material such as hydraulic fluid, alcohol, contaminated combustibles, or some other material is assumed to be present in the room. In addition, adjoining facilities such as offices may exist in the building and add to the risk of fires in the facility. The glove boxes are assumed to fail in the fire. This event is assumed to be a moderate-size room fire. The MOX powder that is in interim storage is assumed to be at risk and subjected to the thermal stress of the fire, because the glove box fails. Because of the limited combustible material and/or the existence of mitigators such as a fire protection system or arrival of the firefighting unit, the event is assumed to be terminated. The severity of this fire is not enough to jeopardize the overall confinement characteristics of the building.

\subsubsection{Source term}

Table 20 shows the materials in process along with the release fractions that were used. With respect to the oxide containers $(10 \mathrm{~kg})$, a high release fraction was selected based on a pressurized gas release combined with powder. This corresponds to a highly pressurized, strong, single can that ruptures under a high thermal stress because of pressure and ejects powder from the breached container. A $10 \%$ damage ratio (thus, $500 \mathrm{~g}$ of powder are subjected to the release fraction) was selected on the basis that the release fraction does not apply universally to all of the powder in the can (the release fraction will go down as larger cans of powder are subjected to the energetics).

The 32-kg inventory in the process area was assumed to be evenly split between the master mix and MOX fuel blend storage areas. The entire interim storage inventory of MOX powder is assumed to be subjected to a release fraction corresponding to thermal stress $\left(6 \times 10^{-3}\right.$ airborne release fraction and a 0.01 respirable fraction from Ref. 5). Green pellets, finished pellets, and fuel rods were not considered to constitute a significant portion of dispersible material. The material is assumed to be filtered and released to a stack. The scrap area was assumed to contain mostly solid material and was not judged to be a significant source of dispersible material. As with other source terms no credit was taken for in-facility filters, as these may fail because of the fire. The source term is filtered and released to a stack.

\subsubsection{Frequency estimate}

The frequency estimate of fires depends on the conduct of operations, the building selected, the adequacy of the fire protection program, and a number of other variables. A frequency estimate of between $1 \times 10^{-2} /$ year and $1 \times 10^{-4} /$ year (unlikely) is judged to be appropriate for this event because a relatively small area is assumed to be involved.

\subsubsection{Evaluation Basis Explosion Event}

\subsubsection{Discussion}

As was the case in Ref. 2, an explosion event was postulated for the sintering furnace in the LA fabrication facility. A nonexplosive mixture of $6 \%$ hydrogen and $94 \%$ argon is used in the furnace. Multiple equipment and operator errors would have to occur to enable an explosive mixture of hydrogen mixed with air to build up in the box. As a result of the explosion, green pellets are assumed to be subjected to the direct force of the resultant shock waves. Unlike Ref. 3, where the facility layout can accommodate segregation (in effect limiting the explosion damage), it is assumed that the glove boxes involved in powder blending are damaged indirectly by the explosion. It is not expected that the shock wave impacting this area would be severe enough to significantly damage all of the storage inventory because interim storage cans would provide some mitigation.

\subsubsection{Source term}

The split in the material at risk (between green pellets, pellets in the furnace, and powder storage areas) is shown in Table 21 for the 32-kg batch. No specific release fractions are given in the literature for 
Table 20. Source term for the evaluation basis fire

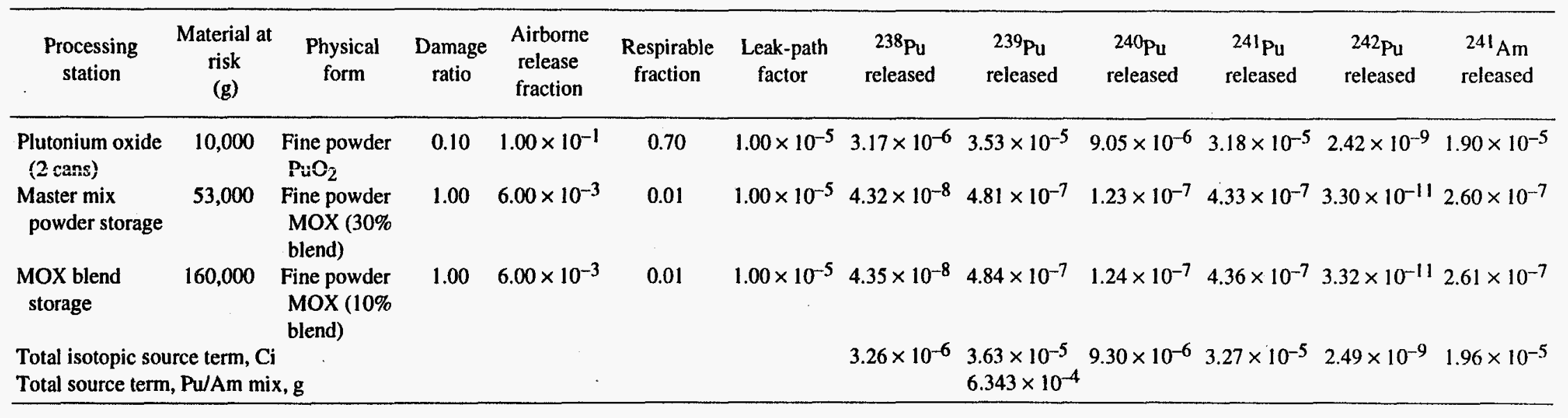


Table 21. Source term for the evaluation basis explosion

\begin{tabular}{|c|c|c|c|c|c|c|c|c|c|c|c|c|}
\hline $\begin{array}{l}\text { Processing } \\
\text { station }\end{array}$ & $\begin{array}{c}\text { Material at } \\
\text { risk } \\
\text { (g) }\end{array}$ & $\begin{array}{l}\text { Physical } \\
\text { form }\end{array}$ & $\begin{array}{c}\text { Damage } \\
\text { ratio }\end{array}$ & $\begin{array}{l}\text { Airborne } \\
\text { release } \\
\text { fraction }\end{array}$ & $\begin{array}{l}\text { Respirable } \\
\text { fraction }\end{array}$ & $\begin{array}{l}\text { Leak-path } \\
\text { factor }\end{array}$ & ${ }^{238} \mathrm{Pu}$ & ${ }^{239} \mathrm{Pu}$ & $\begin{array}{l}{ }^{240} \mathrm{Pu} \\
\text { teleased }\end{array}$ & ${ }^{241} \mathrm{Pu}$ & ${ }^{242} \mathrm{Pu}$ & $\begin{array}{l}241 \mathrm{Am} \\
\text { released }\end{array}$ \\
\hline $\begin{array}{l}\text { Master mix } \\
\text { powder storage }\end{array}$ & 33,000 & $\begin{array}{l}\text { Fine powder } \\
\text { MOX ( } 30 \% \\
\text { blend) }\end{array}$ & 1.00 & $5.00 \times 10^{-3}$ & 0.3 & $1.00 \times 10^{-5}$ & $6.73 \times 10^{-7}$ & $7.49 \times 10^{-6}$ & $1.92 \times 10^{-6}$ & $6.75 \times 10^{-6}$ & $5.14 \times 10^{-10}$ & $4.04 \times 10^{-6}$ \\
\hline $\begin{array}{l}\text { MOX blend } \\
\text { storage }\end{array}$ & 100,000 & $\begin{array}{l}\text { Fine powder } \\
\text { MOX (10\% } \\
\text { blend) }\end{array}$ & 1.00 & $5.00 \times 10^{-3}$ & 0.3 & $1.00 \times 10^{-5}$ & $6.79 \times 10^{-7}$ & $7.57 \times 10^{-6}$ & $1.94 \times 10^{-6}$ & $6.81 \times 10^{-6}$ & $5.19 \times 10^{-10}$ & $4.08 \times 10^{-6}$ \\
\hline $\begin{array}{l}\text { MOX green } \\
\text { pellet storage } \\
\text { (in pellet press } \\
\text { area) }\end{array}$ & 80,000 & $\begin{array}{l}\text { Pressed to } 0.6 \\
\text { TD, MOX } \\
\text { (10\% blend) }\end{array}$ & 1.00 & $1.00 \times 10^{-4}$ & 1 & $1.00 \times 10^{-5}$ & $3.62 \times 10^{-8}$ & $4.04 \times 10^{-7}$ & $1.03 \times 10^{-7}$ & $3.63 \times 10^{-7}$ & $2.77 \times 10^{-11}$ & $2.18 \times 10^{-7}$ \\
\hline $\begin{array}{l}\text { Pellet sintering } \\
\text { furnace }\end{array}$ & 40,000 & $\begin{array}{l}\text { Assume all } \\
\text { green pellets } \\
\text { MOX (10\% } \\
\text { blend) }\end{array}$ & 1.00 & $1.00 \times 10^{-4}$ & 1 & $1.00 \times 10^{-5}$ & $1.81 \times 10^{-8}$ & $2.02 \times 10^{-7}$ & $5.17 \times 10^{-8}$ & $1.82 \times 10^{-7}$ & $1.39 \times 10^{-11}$ & $1.09 \times 10^{-7}$ \\
\hline \multicolumn{7}{|c|}{$\begin{array}{l}\text { Total isotopic source term, } \mathrm{Ci} \\
\text { Total source term, Pu/Am mix, } \mathrm{g}\end{array}$} & $1.41 \times 10^{-6}$ & $\begin{array}{l}1.57 \times 10^{-5} \\
2.739 \times 10^{-4}\end{array}$ & $4.02 \times 10^{-6}$ & $1.41 \times 10^{-5}$ & $1.08 \times 10^{-9}$ & $8.45 \times 10^{-6}$ \\
\hline
\end{tabular}


deflagration forces on green pellets that are pressed to $-60 \%$ theoretical density. Reference 5 , Sect. 4.3.3, discusses a formulation for determining the product of the airborne release fraction and respirable fraction $(A R F * R F)$ for dropped uranium dioxide pellets. A release fraction (combined $A R F * R F$ ) of $1 \times 10^{-4}$ was deemed to be conservative for all material $(40,000 \mathrm{~g})$ in the furnace subjected to explosive forces. This same release and respirable fraction was also used for the green pellets that would be pressed and likely near the furnace. The $80,000 \mathrm{~g}$ of green pellets would be a little further from the blast and in trays or containers. The same release fraction was applied to these green pellets and is thought to be conservative.

The remaining part of the $20-\mathrm{kg}$ batch was assumed to be split between the MOX master blend and powder storage stations. The MOX powder in the blending areas would likely be in a different glove box and somewhat removed from the blast. These glove boxes are assumed to be indirectly damaged from the explosion. As previously stated, most of the storage powder would be in interim cans that would merely be displaced. Powders in a glove box that undergo damage from external explosions are discussed in Ref. 5 (p. 4-69). A release fraction (and respirable fraction) of $5 \times 10^{-3}$ (and 0.3 ) was used and conservatively applied to all of the powder. The total source term is shown in Table 18. The building confinement is judged to be still intact resulting in a filtered stack release.

\subsubsection{Frequency estimate}

Because no definitive designs for the furnace and glove boxes currently exist, estimation of the probability of this event is difficult at this time. A judgment was made that the frequency of this event is extremely unlikely (between $1 \times 10^{-4} /$ year and $1 \times 10^{-6} /$ year). Such an explosion of sufficient size from the furnace to impact the glove boxes would only be possible because of a combination of equipment failure and human error.

\subsubsection{Beyond-Evaluation Basis Seismic Event}

\subsubsection{Discussion}

In this analysis an event much more severe in consequences than what might be expected to be the design basis (or evaluation basis) is examined. For some existing DOE facilities, the estimated seismic frequency for beyond-design basis events can be greater than $1 \times 10^{-6} /$ year. The design basis for every building in the complex varies considerably depending on site specifics and the type of construction used in the building. A damage assessment of the facility is further complicated by the fact that seismic considerations could also be incorporated in the glove box design of the facility. In reality, such a catastrophic event may or may not demolish the building and/or the glove boxes. However, for the purposes of illustrating a high consequence accident (which occurs at a very low frequency), total demolition of the building has been assumed. In this event, no credit is taken for the building, the filters, or the glove boxes.

\subsubsection{Source term}

In the evaluation basis seismic event previously discussed, credit was taken for the $\mathbf{3 0 1 3}$ cans (which have double containment) in the vault storage area. In this event, however, a total building collapse is used, and a judgment was made that a few of the containers may fail. A damage ratio of 0.05 was used; it equates to 4 out of 80 cans in the vault area. For the source term evaluation of the remainder of the in-process material (including the two cans that feed the process), the release fractions were selected to be the same as in the evaluation basis seismic event. However, because it is assumed that the building collapses and the ventilation system is severed, no credit is taken for filtration. This results in a building leak-path factor of 1.0. The source term is assumed to be released at or near ground level $(10 \mathrm{~m})$. Table 22 shows the source term for this event. 
Table 22. Source term for beyond the evaluation basis seismic event (total building collapse assumed)

\begin{tabular}{|c|c|c|c|c|c|c|c|c|c|c|c|c|}
\hline $\begin{array}{l}\text { Processing } \\
\text { station }\end{array}$ & $\begin{array}{c}\text { Material at } \\
\text { risk } \\
\text { (g) }\end{array}$ & $\begin{array}{l}\text { Physical } \\
\text { form }\end{array}$ & $\begin{array}{c}\text { Damage } \\
\text { ratio }\end{array}$ & $\begin{array}{l}\text { Airborne } \\
\text { release } \\
\text { fraction }\end{array}$ & $\begin{array}{l}\text { Respirable } \\
\text { fraction }\end{array}$ & $\begin{array}{l}\text { Leak-path } \\
\text { factor }\end{array}$ & 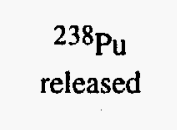 & $\begin{array}{l}{ }^{239} \mathrm{Pu} \\
\text { released }\end{array}$ & $\begin{array}{l}240 \mathrm{Pu} \\
\text { released }\end{array}$ & ${ }^{241} \mathrm{Pu}$ & $\begin{array}{l}{ }^{242} \mathrm{Pu} \\
\text { released }\end{array}$ & $\begin{array}{l}{ }^{241} \mathrm{Am} \\
\text { released }\end{array}$ \\
\hline $\begin{array}{l}\text { Plutonium } \\
\text { storage vault }\end{array}$ & 400,000 & $\begin{array}{l}\text { Fine powder } \\
\mathrm{PuO}_{2}\end{array}$ & 0.05 & $1.00 \times 10^{-3}$ & 0.10 & $1.00 \times 10^{0}$ & $9.06 \times 10^{-3}$ & $1.01 \times 10^{-1}$ & $2.59 \times 10^{-2}$ & $9.08 \times 10^{-2}$ & $6.93 \times 10^{-6}$ & $5.44 \times 10^{-2}$ \\
\hline $\begin{array}{l}\text { Plutonium oxide } \\
\text { ( } 2 \text { cans })\end{array}$ & 10,000 & $\begin{array}{l}\text { Fine powder } \\
\mathrm{PuO}_{2}\end{array}$ & 1.00 & $1.00 \times 10^{-2}$ & 0.20 & $1.00 \times 10^{0}$ & $9.06 \times 10^{-2}$ & $1.01 \times 10^{0}$ & $2.59 \times 10^{-1}$ & $9.08 \times 10^{1}$ & $6.93 \times 10^{-5}$ & $5.44 \times 10^{-1}$ \\
\hline $\begin{array}{l}\text { Master mix } \\
\text { powder storage }\end{array}$ & 53,000 & $\begin{array}{l}\text { Fine powder } \\
\text { MOX ( } 30 \% \\
\text { blend) }\end{array}$ & 1.00 & $1.00 \times 10^{-3}$ & 0.10 & $1.00 \times 10^{0}$ & $7.20 \times 10^{-3}$ & $8.02 \times 10^{-2}$ & $2.06 \times 10^{-2}$ & $7.22 \times 10^{-2}$ & $5.51 \times 10^{-6}$ & $4.33 \times 10^{-2}$ \\
\hline $\begin{array}{l}\text { MOX blend } \\
\text { storage }\end{array}$ & 160,000 & $\begin{array}{l}\text { Fine powder } \\
\text { MOX (10\% } \\
\text { blend) }\end{array}$ & 1.00 & $1.00 \times 10^{-3}$ & 0.10 & $1.00 \times 10^{0}$ & $7.25 \times 10^{-3}$ & $8.07 \times 10^{-2}$ & $2.07 \times 10^{-2}$ & $7.27 \times 10^{-2}$ & $5.54 \times 10^{-6}$ & $4.35 \times 10^{-2}$ \\
\hline \multicolumn{7}{|c|}{ Total isotopic source term, $\mathrm{Ci}$} & $1.14 \times 10^{-1}$ & $\begin{array}{l}1.27 \times 10^{0} \\
22.22\end{array}$ & $3.26 \times 10^{-1}$ & $1.14 \times 10^{-0}$ & $8.72 \times 10^{-5}$ & $6.85 \times 10^{-1}$ \\
\hline
\end{tabular}




\subsubsection{Frequency}

As discussed previously there is great difficulty in assigning a frequency for this event, especially because facilities are not analyzed for very high seismic events that occur with very infrequent return periods. Site specifics make the frequency assessment of this event very uncertain as well. For the sake of this analysis, a frequency value of $1 \times 10^{-6}$ or less is thought to be appropriate for the EIS purposes.

\subsubsection{Beyond-Evaluation Basis Major Building Fire}

\subsubsection{Discussion}

Fuel manufacturing operations do not lend themselves to the use of large significant amounts of combustible material. In this scenario, however, it is assumed that the building is burned for a considerable length of time, resulting in a total collapse of the building. This event could also roughly be characterized as a large fire following a total building collapse.

\subsubsection{Source term}

Some thought was given to the stability of the 3013 cans in the vault which would be subjected to prolonged heat during a large fire. Because of the double containment and high-pressure rating for the cans, it was judged that the cans could withstand a large building fire. However, because a major building fire breaches the confinement, it is assumed that the building structure could collapse. This happens in large buildings subjected to high heat loads for long periods of time. As a result of this consideration, four of the cans in the vault area were assumed to have breached, just as in the beyond-evaluation seismic event. For the two oxide cans in process, it was conservatively assumed that they burst (previously discussed in the evaluation-basis fire scenario). The remainder of the $32-\mathrm{kg}$ inventory was assumed to be subjected to a release fraction corresponding to falling debris in cans (similar to a seismic event). The total estimated source term is shown in Table 23. However, because considerable heat is produced by the fire, a significant plume rise would occur. Therefore, a release height of $100 \mathrm{~m}$ was judged to be appropriate for this event.

\subsubsection{Frequency}

Assigning a frequency for this event is difficult because significant combustible loads are not placed in close proximity to the process. This is a very low frequency noncredible event, which requires the introduction of significant combustibles that would create a fire large enough to collapse the structure. For the sake of this analysis, a frequency value of much less than $1 \times 10^{-7}$ is thought to be appropriate for the EIS purposes.

\subsection{EVALUATION OF POTENTIAL CHEMICAL SOURCE TERMS}

Chemical and radiological materials used in this facility were previously given in Table 6. With respect to radiological effects, the source terms associated with plutonium oxide constitute an overwhelming majority of the radiological risk. With respect to the chemical hazards associated with depleted $\mathrm{UO}_{2}$ (which are released in conjunction with the plutonium oxide in the scenarios outlined in the previous sections), no specific source terms have been generated in this analysis. As discussed in previous sections, only small amounts of plutonium (generally $<1 \mathrm{~g}$ ) constitute the source terms. If treated similarly (from a release standpoint), small amounts of the depleted uranium that may accompany the plutonium oxide that escapes the building are judged to be inconsequential.

Table 6 also gives the other chemicals and compounds that will be used annually by the facility and lists the yearly consumption of gases, liquids, and solids. With respect to any possibly chemical source term, the gases listed (i.e., helium, hydrogen, nitrogen, and oxygen) do not constitute an inhalation or exposure hazard in the context of LA fabrication operations. Reportable quantities of various chemical 
Table 23. Source term for beyond the evaluation basis major building fire/building collapse (total building collapse assumed to result; source term release height $=100 \mathrm{~m}$ )

\begin{tabular}{|c|c|c|c|c|c|c|c|c|c|c|c|c|}
\hline $\begin{array}{l}\text { Processing } \\
\text { station }\end{array}$ & $\begin{array}{c}\text { Material at } \\
\text { risk } \\
(\mathrm{g})\end{array}$ & $\begin{array}{c}\text { Physical } \\
\text { form }\end{array}$ & $\begin{array}{c}\text { Damage } \\
\text { ratio }\end{array}$ & $\begin{array}{l}\text { Airborne } \\
\text { release } \\
\text { fraction }\end{array}$ & $\begin{array}{l}\text { Respirable } \\
\text { fraction }\end{array}$ & $\begin{array}{l}\text { Leak-paih } \\
\text { factor }\end{array}$ & 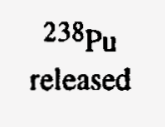 & $\begin{array}{l}{ }^{239} \mathrm{Pu} \\
\text { released }\end{array}$ & $\begin{array}{l}{ }^{240} \mathrm{Pu} \\
\text { released }\end{array}$ & 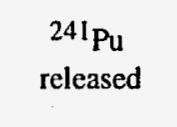 & 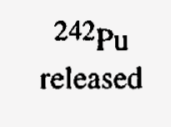 & ${ }^{241} \mathrm{Am}$ \\
\hline $\begin{array}{l}\text { Plutonium } \\
\text { storage vault }\end{array}$ & 400,000 & $\begin{array}{l}\text { Fine powder } \\
\mathrm{PuO}_{2}\end{array}$ & 0.05 & $1.00 \times 10^{-3}$ & 0.10 & $1.00 \times 10^{0}$ & $9.06 \times 10^{-3}$ & $1.01 \times 10^{-1}$ & $2.59 \times 10^{-2}$ & $9.08 \times 10^{-2}$ & $6.93 \times 10^{-6}$ & $5.44 \times 10^{-2}$ \\
\hline $\begin{array}{l}\text { Plutonium oxide } \\
\text { ( } 2 \text { cans) }\end{array}$ & 10,000 & $\begin{array}{l}\text { Fine powder } \\
\mathrm{PuO}_{2}\end{array}$ & 0.10 & $1.00 \times 10^{-1}$ & 0.70 & $1.00 \times 10^{0}$ & $3.17 \times 10^{-1}$ & $3.53 \times 10^{0}$ & $9.05 \times 10^{-1}$ & $3.18 \times 10^{0}$ & $2.42 \times 10^{-4}$ & $1.90 \times 10^{0}$ \\
\hline $\begin{array}{l}\text { Master mix } \\
\text { powder storage }\end{array}$ & 53,000 & $\begin{array}{l}\text { Fine powder } \\
\text { MOX ( } 30 \% \\
\text { blend) }\end{array}$ & 1.00 & $1.00 \times 10^{-3}$ & 0.10 & $1.00 \times 10^{0}$ & $7.20 \times 10^{-3}$ & $8.02 \times 10^{-2}$ & $2.06 \times 10^{-2}$ & $7.22 \times 10^{-2}$ & $5.51 \times 10^{-6}$ & $4.33 \times 10^{-2}$ \\
\hline $\begin{array}{l}\text { MOX blend } \\
\text { storage }\end{array}$ & 160,000 & $\begin{array}{l}\text { Fine powder } \\
\text { MOX }(10 \% \\
\text { blend })\end{array}$ & 1.00 & $1.00 \times 10^{-3}$ & 0.10 & $1.00 \times 10^{0}$ & $7.25 \times 10^{-3}$ & $8.07 \times 10^{-2}$ & $2.07 \times 10^{-2}$ & $7.27 \times 10^{-2}$ & $5.54 \times 10^{-6}$ & $4.35 \times 10^{-2}$ \\
\hline \multicolumn{7}{|c|}{$\begin{array}{l}\text { Total isotopic source term, } \mathrm{Ci} \\
\text { Total source term, } \mathrm{Pu} / \mathrm{Am} \text { mix, } \mathrm{g}\end{array}$} & $3.41 \times 10^{-1}$ & $\begin{array}{l}3.79 \times 10^{0} \\
66.32\end{array}$ & $9.72 \times 10^{-1}$ & $3.42 \times 10^{0}$ & $2.60 \times 10^{-4}$ & $2.05 \times 10^{0}$ \\
\hline
\end{tabular}


compounds are cited in 40 CFR 302, Table 302.4. If a chemical company operator spills less than these quantities, the Environmental Protection Agency is not notified. While this is not an absolute criterion that guarantees the lack of off-site consequences, it is illustrative to examine the yearly flow of chemicals based on these reported quantities.

Table 24 compares the annual usage of chemicals to the reportable quantities for that material. While not all materials are listed, the comparison shows that the LA facility does not constitute a major source of chemical inventories. The chemicals listed are either in a liquid or solid form, and the gases listed are not hazardous from an inhalation perspective. Typical occupational chemical exposure incidents, such as acid burns to a worker, are certainly credible. A significant release scenario (inhalation risk, ingestion risk, or skin contact risk) that constitutes a source term (with a magnitude of reasonable concern) to a receptor is difficult to credibly postulate at this stage of the facility analysis. Because of the small size of the facility and the small quantities of chemicals that are expected to be on hand, it is concluded that no chemical source terms are worthy of analysis (that are beyond what is found in small standard industrial facilities). The amounts that would be in use by this facility are certainly considered to be well within the scope of typical industrial hazards found in laboratory environrnents.

\subsection{SITE SPECIFICS FOR THE SRS BUILDINGS}

The following seismic evaluations do not consider the equipment specifics that would be involved in the MOX LA fabrication line and represent an estimate for the building and confinement-related ventilation system. Cross-comparisons of frequencies and evaluation basis values for sites must be performed with caution. Such simple comparisons do not take into account the differences in analytical approaches that were used at each site to estimate the building response, acceleration, or estimated frequency for the site. As a general rule for all sites, it is expected that the evaluation basis frequency for a seismic event would be from $1 \times 10^{-2} /$ year to $1 \times 10^{-4} /$ year and would likely be between $1 \times 10^{-3} /$ year and $1 \times 10^{-4} /$ year or less.

\subsubsection{Stack Release Height for Building 221-F and -H (Category I)}

For Building 221-F and $-\mathrm{H}$, the stack release height is $\sim 59.4 \mathrm{~m}(\sim 195 \mathrm{ft})$.

Table 24. Comparison of LA facility annual usage and reportable quantity per 40 CFR 302

\begin{tabular}{lcl}
\hline \multicolumn{1}{c}{ Item } & $\begin{array}{c}\text { Annual average } \\
\text { consumption }\end{array}$ & $\begin{array}{c}\text { Reportable } \\
\text { quantity }\end{array}$ \\
\hline Liquids & $1 \mathrm{lb}$ & $5,000 \mathrm{lb}$ \\
$\quad$ Hydrochloric acid & $2 \mathrm{lb}$ & $1,000 \mathrm{lb}$ \\
Nitric acid & $<45 \mathrm{lb}$ & Not listed \\
Polyethylene glycol & $5 \mathrm{lb}$ & $1,000 \mathrm{lb}$ \\
Sulfuric acid & & \\
Solids & $34 \mathrm{lb}$ & $1,000 \mathrm{lb}$ \\
Sodium hydroxide & $<200 \mathrm{lb}$ & Not listed \\
Sodium nitrate & $<45 \mathrm{lb}$ & Not listed \\
Zinc stearate & & \\
Nonprocess chemicals & $60 \mathrm{gal}$ & Not listed \\
Alcohol & $10 \mathrm{lb}$ & Not listed \\
Hydraulic fluid & 60 gal & Not listed \\
General cleaning fluids & &
\end{tabular}




\subsubsection{Evaluated Seismic Attributes for Building 221-F and -H (Category I)}

For the Building $221-\mathrm{F}$ and $-\mathrm{H}$, the current peak ground acceleration value of the evaluated basis earthquake for the building is a $0.16 \mathrm{~g}$ seismic event, with an estimated frequency of $5 \times 10^{-4}$ /year. The sand filters, fan house, air tunnels, and reinforced concrete portion of the stack were also analyzed to this value.

\subsubsection{Stack Release Height for Building 773-A (Non-Category I)}

For Building 773-A, the B- and C-Wing exhaust stacks are 75-ft high.

\subsubsection{Evaluated Seismic Attributes for Building 773-A (Non-Category I)}

Building 773-A meets the DOE standard 1020 performance Category 3 seismic criteria. 
Page Intentionally Blank 


\section{TRANSPORTATION}

\subsection{OPERATIONS-RELATED TRANSPORTATION REQUIREMENTS}

Production of MOX fuel LAs, irradiation of the LAs in commercial reactors, and subsequent PIE will result in a number of packaging and transportation operations to (1) obtain the necessary feed materials to manufacture LAs, (2) package and transport the completed fuel assemblies from the fabrication facility to the commercial reactor, and (3) package and transport the irradiated fuel assemblies from the commercial reactor to another facility for PIE.

Plans for MOX fuel LA testing involve manufacture of up to ten MOX fuel LAs, with up to eight LAs undergoing irradiation while the remaining LAs are maintained as unirradiated archives. Each LA could contain from as few as one-third MOX rods (with the balance of the rods being LEU) to an entire assembly composed of MOX rods. Under these circumstances, production of LA will require that LEU and MOX fuel rods be combined in a single assembly. This activity could occur at either the LA fabrication facility or at the reactor facility. While reactors generally have the ability to substitute individual rods within an assembly (due to detected damage), it is expected that exchanging as many as one-third of the LEU assembly rods with MOX rods would occur at the LA facility.

\subsubsection{Feed Materials}

Table 25 provides information about the shipment of $\mathrm{PuO}_{2}$. Table 26 provides information about the shipment of depleted $\mathrm{UO}_{2}$. Depleted $\mathrm{UO}_{2}$ can be obtained by the consortium, or DOE will provide either depleted uranium fluoride $\left(\mathrm{DUF}_{6}\right)$ or depleted uranium oxide $\left(\mathrm{DUO}_{3}\right)$ for conversion by the consortium. Other materials (e.g., new empty fuel rods, end plugs, grid spacers, and other assembly hardware) are not "regulated" materials for transportation. Their shipment would not require special packaging, other than to protect the economic value of the commodity. The specific LA design is uncertain. Some designs may have every fuel rod contain MOX, while other designs may have both $\mathrm{MOX}$ and $\mathrm{UO}_{2}$ fuel rods within a bundle. In the latter case, it would be necessary to either ship enriched $\mathrm{UO}_{2}$ fuel rods (or $\mathrm{UO}_{2}$ fuel rods in LEU fuel assemblies) to the MOX fabrication facility or to ship MOX fuel rods from the fabrication facility to the commercial fuel fabrication site (for insertion in LEU fuel assemblies shipped separately to the reactor). If the MOX LA will contain a large fraction of MOX rods (one-third or more), it is expected that the LA facility will need to receive LEU fuel assemblies (possibly, with unfilled rod positions) from a commercial fuel vendor. The LA fuel facility would then place MOX rods within the assembly and package the MOX LA for shipment to the reactor. Table 27 provides information on the shipment of LEU fuel assemblies to the MOX LA fuel facility, if needed.

\subsubsection{Fresh MOX Fuel Assemblies}

Table 28 provides information about the transport of fresh (unirradiated) MOX fuel from the fabrication facility to the commercial reactor, while Table 29 provides the fresh MOX fuel isotopic contents. The same package identified for shipment of the MOX fuel assemblies (the MO-1) would also be used to ship groups of individual MOX fuel rods to a commercial fuel fabrication site for insertion in a MOX fuel bundle if this approach is used.

\subsubsection{Spent MOX Fuel Assemblies}

Tables 30 and 31 provide information about the transport of spent (irradiated) MOX fuel from the commercial reactor to the PIE facility. Table 32 provides information regarding existing casks that could be used to transport spent MOX fuel to the PIE facility. The number of shipments of spent MOX fuel will depend on the actual plans for LA irradiation and plans for subsequent PIE. Based on the schedule described in Fig. 2, up to eight shipments of LA spent fuel could be transported between the reactor and the PIE facility. 
Table 25. Transportation of $\mathrm{PuO}_{2}$ to support LA fabrication

Number of shipments to LA fabrication site ${ }^{a}$

1 or more

Assuming $321 \mathrm{~kg} \mathrm{HM}$ as $\mathrm{PuO}_{2}$ is needed for startup and to produce $10 \mathrm{LTAs}$

Would require about 73 packages ( $4.4 \mathrm{~kg} \mathrm{HM}$ /package). SST could accommodate 30 to 35 packages per trailer. Single SST convoy (three trailers) could deliver entire $\mathrm{PuO}_{2}$ supply for LTA campaign

Container types used for shipments

Availability of containers

Likely candidate package would be 9968 or 9975 , perhaps SAFKEG

Only 9968 is currently certified

Average shipping container weight

Average material weight loaded into container

Average isotopic contents

Average exposure rate at $1 \mathrm{~m}$

Maximum anticipated dose rate at $1 \mathrm{~m}$

Type B

Yes

Will need to be determined

Regulatory limits are $200 \mathrm{mrem} / \mathrm{h}$ at surface of package $(1000 \mathrm{mrem} / \mathrm{h}$ for closed transport vehicles, exclusive use, cargo secured); $200 \mathrm{mrem} / \mathrm{h}$ (outer surface of vehicle); $10 \mathrm{mrem} / \mathrm{h}$ at point $2 \mathrm{~m}$ from package surface; and $2 \mathrm{mrem} / \mathrm{h}$ (in occupied spaces) (i.e., crew cab, etc.)

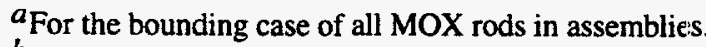

$b_{\text {See Table } 29 .}$

Table 26. Transportation of depleted $\mathrm{UO}_{2}$ to support $\mathrm{LA}$ fabrication ${ }^{a, b}$

Number of shipments to LA fabrication site

1

$\mathrm{UO}_{2}$ is shipped in standard metal drums

Truck could accommodate $40,000 \mathrm{lb}(\sim 72$ drums $)$

Mission would only require about 28 drums $\mathrm{UO}_{2}$

Container types used for shipments

208-L drum

A strong-tight container (open head 55-gal drum)

$165 \mathrm{~kg}(360 \mathrm{lb})$

$4.4-4.5 \mathrm{~kg} \mathrm{HM}$

$b$

$0.1 \mathrm{mrem} / \mathrm{h}$

$10 \mathrm{mrem} / \mathrm{h}$

Probably use UN1A2 (steel drum)

Availability of containers

Yes

Average shipping container weight, $\mathrm{kg}$ (lb)

Average material weight loaded into container

$275 \mathrm{~kg}(600 \mathrm{lb})$

$250 \mathrm{~kg}$

Average isotopic contents

Average exposure rate at $1 \mathrm{~m}$

Depleted uranium ${ }^{a}$

$\sim 0$

Maximum anticipated dose rate at $1 \mathrm{~m}$

$10 \mathrm{mrem} / \mathrm{h}$

Will need to be determined

Regulatory limits are $200 \mathrm{mrem} / \mathrm{h}$ at surface of package $(1000 \mathrm{mrem} / \mathrm{h}$ for closed transport vehicles, exclusive use, cargo secured); $200 \mathrm{mrem} / \mathrm{h}$ (outer surface of vehicle); $10 \mathrm{mrem} / \mathrm{h}$ at point $2 \mathrm{~m}$ from package surface; and $2 \mathrm{mrem} / \mathrm{h}$ (in occupied spaces) (i.e., crew cab, etc.)

${ }^{a}$ See Ref. 3 for more information on depleted uranium. Refer to Table 29 for uranium isotopic content.

$b_{\text {Unlike }} \mathrm{UF}_{6}$ cylinders, depleted $\mathrm{UO}_{2}$ is purified, with daughter products removed that result in potential doses. 
Table 27. Transportation of materials to support LA fabrication (LEU fuel assemblies)

Number of shipments of LA fabrication site 1

Assuming that all 10 LEU assemblies could be shipped on a

single commercial vehicle (just as LEU fuel is shipped

currently). Would require use of 5 LEU fuel packages.

Container types used for shipments

Availability of containers

Average shipping container weight, $\mathrm{kg}(\mathrm{lb})$

Average material weight loaded into container

Average isotopic contents

Average exposure rate at $1 \mathrm{~m}, \mathrm{mR} / \mathrm{h}$

Maximum anticipated dose rate at $1 \mathrm{~m}, \mathrm{mR} / \mathrm{h}$

Will need to be determined

Regulatory limits are $200 \mathrm{mrem} / \mathrm{h}$ at surface of package $(1000 \mathrm{mrem} / \mathrm{h}$ for closed transport vehicles, exclusive use, cargo secured); $200 \mathrm{mrem} / \mathrm{h}$ (outer surface of vehicle); $10 \mathrm{mrem} / \mathrm{h}$ at point $2 \mathrm{~m}$ from package surface; and $2 \mathrm{mrem} / \mathrm{h}$ (in occupied spaces) (i.e., crew cab, etc.)

Table 28. Transportation of LAs to generic reactor site

Number of SST shipments of LAs to generic reactor

Assuming two shipments (four assemblies) each, to two different reactors, with two additional assemblies archived

Type of containers used for shipments

Likely candidate is the MO-1, USA/9069/B

Potential problems-NRC may require additional analysis to continue inclusion of MOX contents on package certificate. Also, MO-1 certificate lists $85 \%$ fissile plutonium in total plutonium. WG MOX would be $-94 \%$, so additional analysis is needed to ensure that LTAs can be transported in MO-1 (may need to enhance criticality controls)

No package currently available in the United States for boiling-water reactor (BWR) MOX assemblies; probably could amend MO-1 certificate to allow two BWR assemblies

Availability of containers

Average shipping container weight

Gross weight, including two pressurized-water reactor (PWR) fuel assemblies

Average material weight loaded into shipping container

Average isotopic content (by isotope, mass \% content)

Average exposure rate at $1 \mathrm{~m}$

Will need to be determined, both for worker doses as well as transportation risk assessment

Should be fairly low

Maximum anticipated dose rate at $1 \mathrm{~m}$

Will need to be determined

Regulatory limits are $200 \mathrm{mrem} / \mathrm{h}$ at surface of package $(1000 \mathrm{mrem} / \mathrm{h}$ for closed transport vehicles, exclusive use, cargo secured); $200 \mathrm{mrem} / \mathrm{h}$ (outer surface of vehicle); $10 \mathrm{mrem} / \mathrm{h}$ at point $2 \mathrm{~m}$ from package surface; and $2 \mathrm{mrem} / \mathrm{h}$ (in occupied spaces) (i.e., crew cab, etc.)
Type AF

Yes

$2900 \mathrm{~kg}(6300 \mathrm{lb})$ to

$3800 \mathrm{~kg}(8400 \mathrm{lb})$

$1400 \mathrm{~kg}(3000 \mathrm{lb})$

LEU, up to $5 \%{ }^{235} \mathrm{U}$

$\sim 0$ (not measurable)

$10 \mathrm{mrem} / \mathrm{h}$

Type B package

Only two MO-1

packages exist

$3900 \mathrm{~kg}(8600 \mathrm{lb})$

$-1400 \mathrm{~kg}(3000 \mathrm{lb})$

$a$

$0.1 \mathrm{mrem} / \mathrm{h}$

$10 \mathrm{mrem} / \mathrm{h}$

${ }^{a}$ See Table 29. 
Table 29. Fresh MOX fuel isotopic content ${ }^{a}$

\begin{tabular}{cc}
\hline $\begin{array}{c}\text { Average isotopic content } \\
(\%)\end{array}$ & $\begin{array}{c}\text { Mass content } \\
(\%)\end{array}$ \\
\hline $235 \mathrm{U}, 0.2$ & 0.1915 \\
$238 \mathrm{U}, 99.8$ & 95.556 \\
$236 \mathrm{Pu},<1 \mathrm{ppb}$ & - \\
$238 \mathrm{Pu}, 0.03$ & 0.00053 \\
$239 \mathrm{Pu}, 92.44$ & 3.995 \\
$240 \mathrm{Pu}, 6.47$ & 0.2485 \\
$241 \mathrm{Pu}, 0.05$ & 0.00592 \\
$242 \mathrm{Pu}, 0.1$ & 0.00249 \\
$241 \mathrm{Am}, 0.9$ & 0.004 \\
\hline
\end{tabular}

$a_{\text {Source: Ref. } 2 .}$

Note: MOX fuel will be produced with various plutonium concentrations depending on the mission reactors.

Table 30. Transportation of irradiated LAs to PIE site

Number of shipments of irradiated LAs to PIE site

Depending on cask selection, see Table 32

Types of container used for shipments

Availability of shipping containers

Several available choices dependent on previous commitments, ability of facilities to handle particular packages

Possible choices-NAC-LWT or NLI. Each would hold one PWR or two BWR assemblies

Average shipping container weight

Average material weight

Average isotopic content

Uranium, transuranics, fission products (dependent on burnup and decay time)

Average exposure rate at $1 \mathrm{~m}(\mathrm{mrem} / \mathrm{h})$ dependent on burnup and decay time

Maximum anticipated dose rate at $1 \mathrm{~m}$

Dependent on fuel burnup and decay plus selection of package

Must be below regulatory limits
Up to 8

Type B

Yes

${ }^{a}$ Each cask will be loaded to the maximum capacity without exceeding regulatory dose limits. 
Table 31. Spent MOX fuel isotopic content

\begin{tabular}{lc}
\hline Isotope & Mass content ${ }^{a}$ (g/assembly) \\
\hline & Actinides \\
${ }^{234} \mathrm{U}$ & $1.28 \times 10^{1}$ \\
${ }^{235} \mathrm{U}$ & $3.56 \times 10^{2}$ \\
$236 \mathrm{U}$ & $1.13 \times 10^{2}$ \\
$238 \mathrm{U}$ & $4.25 \times 10^{5}$ \\
$237 \mathrm{~Np}$ & $8.42 \times 10^{1}$ \\
$238 \mathrm{Pu}$ & $9.70 \times 10^{1}$ \\
$239 \mathrm{Pu}$ & $6.99 \times 10^{3}$ \\
$240 \mathrm{Pu}$ & $4.06 \times 10^{3}$ \\
$241 \mathrm{Pu}$ & $1.49 \times 10^{3}$ \\
${ }^{242} \mathrm{Pu}$ & $7.50 \times 10^{2}$ \\
${ }^{241} \mathrm{Am}$ & $1.04 \times 10^{3}$ \\
$242 \mathrm{Am}$ & $3.22 \times 10^{0}$ \\
$243 \mathrm{Am}$ & $2.03 \times 10^{2}$ \\
$242 \mathrm{Cm}$ & $8.39 \times 10^{-3}$ \\
${ }^{243} \mathrm{Cm}$ & $8.73 \times 10^{-1}$ \\
$244 \mathrm{Cm}$ & $5.38 \times 10^{1}$ \\
$245 \mathrm{Cm}$ & $5.40 \times 10^{0}$ \\
& \\
${ }^{90} \mathrm{Sr}$ & Fission products \\
$106 \mathrm{Ru}$ & $1.31 \times 10^{2}$ \\
$126 \mathrm{Sn}$ & $1.77 \times 10^{-1}$ \\
$126 \mathrm{Sb}$ & $2.22 \times 10^{1}$ \\
$134 \mathrm{Cs}$ & $1.06 \times 10^{-6}$ \\
$137 \mathrm{Cs}$ & $2.81 \times 10^{0}$ \\
$144 \mathrm{Ce}$ & $6.21 \times 10^{2}$ \\
$147 \mathrm{Pm}$ & $2.21 \times 10^{-2}$ \\
$148 \mathrm{Nd}$ & $6.71 \times 10^{0}$ \\
${ }^{154} \mathrm{Eu}$ & $2.25 \times 10^{2}$ \\
\hline & $1.30 \times 10^{1}$ \\
\hline
\end{tabular}

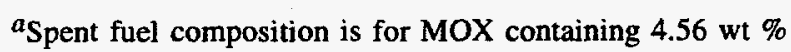
plutonium at a burnup of $45 \mathrm{GWd} / \mathrm{MT}, 10$ years after discharge. Table includes only most significant isotopes.

Source: Memorandum, B. D. Murphy to R. T. Primm III, "Computational Support to Yucca Mountain Project Environmental Impact Statement Data Call," September 12, 1997. 
Table 32. Examples of casks for LWR spent fuel

\begin{tabular}{|c|c|c|c|c|c|}
\hline Name & Owner & Certification No. & $\begin{array}{l}\text { Gross } \\
\text { weight } \\
\text { (lb) }\end{array}$ & Cavity size & Contents \\
\hline NAC-LWT & $\begin{array}{l}\text { NAC } \\
\text { International, } \\
\text { Norcross, GA }\end{array}$ & $\mathrm{USA} / 9225 / \mathrm{B}(\mathrm{U}) \mathrm{F}$ & 51,200 & $\begin{array}{l}181 \text { in. long by } 13.4 \text {-in. } \\
\text { diam }\end{array}$ & $\begin{array}{l}1 \text { PWR or } \\
2 \text { BWR } \\
\text { assemblies }\end{array}$ \\
\hline $\mathrm{NLI}-1 / 2$ & $\begin{array}{l}\text { NAC } \\
\text { International, } \\
\text { Norcross, GA }\end{array}$ & USA/9010/B()F & 49,250 & $\begin{array}{l}178 \text { in. long by } 13.4 \text {-in. } \\
\text { diam }\end{array}$ & $\begin{array}{l}1 \mathrm{PWR} \text { or } \\
2 \mathrm{BWR} \\
\text { assemblies }\end{array}$ \\
\hline TN-8L & $\begin{array}{l}\text { Transnuclear, } \\
\text { Hawthorne, NY }\end{array}$ & USA/9015/B( )F & 79,380 & $\begin{array}{l}3 \text { cavities, } \\
9 \text { in. } \times 9 \text { in. } \times 168.5 \text { in. }\end{array}$ & $\begin{array}{l}3 \text { PWR } \\
\text { assemblies }\end{array}$ \\
\hline TN-9 & $\begin{array}{l}\text { Transnuclear, } \\
\text { Hawthorne, NY }\end{array}$ & USA/9016/B( )F & 79,200 & $\begin{array}{l}7 \text { cavities, } \\
\sim 6 \text { in. } \times 6 \text { in. } \times 178 \text { in. }\end{array}$ & $\begin{array}{l}7 \text { BWR } \\
\text { assemblies }\end{array}$ \\
\hline
\end{tabular}




\section{QUALITATIVE DECONTAMINATION AND DECOMMISSIONING DISCUSSION}

\subsection{INTRODUCTION}

The DOE facilities that will be used in the fabrication of MOX LAs have been used previously in the handling of nuclear materials. Because most of the facilities are contaminated to some degree, the MOX mission should have few incremental effects on the ultimate D\&D of these facilities. The intent of the Fissile Materials Disposition Program is to decontaminate the facilities to levels that would permit unrestrictive further use of the facilities.

\subsection{PROCESS PLAN}

The development of a detailed D\&D plan will be necessary to minimize waste generation. Waste minimization during D\&D begins with the design of the MOX facility as discussed below. During the D\&D phase, waste minimization measures would be similar to those required in the operation of any nuclear contamination zone. This includes reducing the number of items taken into a contamination zone to the minimum necessary to perform the job.

\subsection{D\&D OPERATIONS}

Because plutonium is primarily an alpha emitter, containment of contamination is a principle concern in the design and operation of a MOX plant. The process involves two distinctly different areas concerning contamination: (1) pellet fabrication where dusty powders of plutonium and uranium oxides are handled and (2) the rod and bundle assembly areas where little if any contamination should be present. At least $95 \%$ of the waste that will be generated during $D \& D$ will be from the pellet fabrication area.

In the pellet fabrication area, a principle concern must be containment of the potential contamination from the copious quantities of plutonium and uranium dust that will be generated during operation of the dry processes. To minimize future D\&D costs, the containment of this potential contamination at its source of generation must be considered in the design of the MOX facility. This design should include local filtration at the source with no contamination allowed in the duct systems.

The rod and bundle assembly areas will use about $50 \%$ of the total space in the MOX facility and should be relatively contamination free. This space could be returned to beneficial occupancy soon after completion of the mission by simply removing the process equipment. Most of the uncontaminated rod and bundle assembly equipment will likely be useful in the full-scale MOX plant and could be shipped to that facility in the future.

Most of the waste generated during D\&D will come from the pellet fabrication area in the disassembly and disposal of contaminated process equipment items and excess glove boxes. The waste generated during $D \& D$, in addition to the contaminated equipment items and glove boxes, will be similar to the waste generated during operation of the MOX plant. This will consist of solid and liquid radioactive waste in similar types and volumes that will be generated during operations. The ratio of TRU to LLW likely will be higher during $D \& D$ from the cleanup of the plutonium contamination in the glove boxes. The emissions during D\&D should be no more than during the operating phase of the LA MOX plant.

Complete decontamination probably will not be possible for most of the glove boxes and contaminated equipment items, and disposal as either LLW or TRU waste will be required. Most of the large equipment items and excess glove boxes likely will be packaged in large B-25 ( $4 \mathrm{ft} \times 4 \mathrm{ft} \times 6 \mathrm{ft}$ ) metal waste boxes. Size reduction of some equipment items and glove boxes likely will be required to fit within these boxes. The assay of the TRU content in some contaminated equipment items will be difficult to determine because of the difficulty of establishing calibration standards for the assay equipment. Also, the waste acceptance criteria for such "difficult to certify" TRU waste items for WIPP disposal have not been completely resolved by DOE. 
The equipment in the rod and bundle assembly areas either will not be contaminated or probably can be decontaminated to clean release standards for unrestricted use. The disposal of this equipment should present no particular problem. 


\section{PIE}

The two sites being considered for the PIE are Argonne National Laboratory-West (ANL-W) and ORNL. The facilities and infrastructure required to complete all PIE activities for the LA program currently exist at both sites. Accommodation of full-length fuel rods is the only modification required at ANL-W or ORNL to process the materials associated with this program. Both sites currently process equivalent materials to those expected in this program, and program activities will be routine.

Table 33 shows the wastes estimated during the LA PIE. Table 34 shows the possible employee radiation doses involved during PIEs of the LAs, and Table 35 lists the estimated PIEs for the EIS.

Figure 9 shows the location of Building 3525 on the ORNL site, and Fig. 10 shows the location of Building 785 on the ANL-W site. These buildings could be used to perform all PIE activities.

\subsection{PIE DISCUSSION}

PIE begins by shipping either the fuel assembly or the individual rods to the PIE facility. Shipment of selected individual rods is desired as it eliminates a handling step at the PIE facility (disassembly of the fuel assembly) and reduces the amount of irradiated fuel that needs to be handled (because only a fraction of the rods in a bundle is examined), stored, and disposed of at the hot cell.

Once the rods are in the hot cell at the PIE facility they are first subjected to a nondestructive examination. The degree of examination varies, but typically the rods are visually examined for signs of damage or wear, their length and diameter is measured, and individual rods may be weighed. After this simple check, additional examinations include eddy current or ultrasonic testing to locate cracks or flaws; leak testing to determine gas containment; gamma scanning to determine the internal fuel rod integrity, migration of fission products, and burnup; neutron radiography and X-ray radiography to determine the internal physical configuration; and detailed visual examination of any crud or oxide layers on the surface of the clad. The particular techniques employed will depend on the program needs.

After the nondestructive testing has been satisfied, the destructive testing often begins by sampling the fission gas pressure and composition in the rod plenum by puncturing the end of the rod and collecting the gas. The rod may then be cut into segments for fuel examination. Thin sections of the rod are often cut off, mounted in epoxy resin, and polished for metallographic and ceramographic examinations. Additional portions of the fuel rod may be cut up for further fuel and clad examinations. Thin cross sections of the rod may be core drilled for fuel samples and the cores examined by gamma scanning or subjected to radiochemistry examination by dissolution in a chemical solution. The solution may undergo chemical analysis, gamma counting, and/or mass spectrometry for the determination of burnup and fission product composition.

Fuel specimens may undergo density measurements, pore size measurements, thermal diffusivity measurements, specific heat determination, melting point temperature estimation, oxygen to metal ratio measurements, and/or fission gas diffusivity depending on the degree of the investigation and the equipment available.

The rod cross sections may also be mounted in special mounts for examination by microprobe, optical microscope, transmission electron microscopy, and/or scanning electron microscope. Other techniques such as X-ray fluorescence and emission spectroscopy may be used depending on the needs of the investigation. These techniques allow the experimenter to determine the amounts and distribution of fission products, plutonium, uranium, and some trace elements. Such analyses allow the experimenter to compare the results of the irradiation with predictions and to investigate fuel behavior in considerable detail.

Clad specimens for mechanical testing may be prepared by segmenting the fuel rod and sliding the fuel out if possible, drilling the fuel out, or cutting and peeling the clad from the fuel. Once prepared, the clad may be subjected to a wide variety of tests such as tensile testing, burst testing, hardness testing, ductility testing, creep tests, fatigue testing, and chemical surface analysis.

All of these tests are considered to be normal PIE practices. The scope of the required equipment can be as simple as a small numbered scale to complex expensive shielded special purpose microscopes. Two references for PIE work are the Guidebook on Non-Destructive Examination of Water Reactor Fuel, IAEA 
Table 33. Estimated waste generated during the LA PIE

\begin{tabular}{|c|c|c|c|c|}
\hline Waste category & Annual volume & $\begin{array}{l}\text { Total estimated volume } \\
\text { (based on } 4 \text { years) }\end{array}$ & $\begin{array}{l}\text { Waste description } \\
\text { (e.g., glove box gloves, cleaning } \\
\text { solvent, paper wipes) }\end{array}$ & $\begin{array}{l}\text { Anticipated treatment and/or } \\
\text { disposal method (e.g., } \\
\text { solidification) } \\
\text { (specify on-site or off-site) }\end{array}$ \\
\hline $\begin{array}{l}\text { TRU } \\
\text { Liquid } \\
\text { Solid }\end{array}$ & $\begin{array}{l}107 \mathrm{~L}(28.2 \mathrm{gal}) \\
2.6 \mathrm{~m}^{3}\left(91.8 \mathrm{ft}^{3}\right)\end{array}$ & $\begin{array}{l}427 \mathrm{~L}(112.8 \mathrm{gal}) \\
10.4 \mathrm{~m}^{3}\left(367.3 \mathrm{ft}^{3}\right)\end{array}$ & $\begin{array}{l}\text { Paper wipes, plastic, glassware, metal } \\
\text { containers, fuel debris, clad pieces, } \\
\text { radiochemical solutions }\end{array}$ & $\begin{array}{l}\text { Solid material packaged in drums } \\
\text { for shipment to WIPP; liquids } \\
\text { processed on-site for later off-site } \\
\text { disposal as LLW }\end{array}$ \\
\hline $\begin{array}{l}\text { Mixed TRU } \\
\text { Liquid } \\
\text { Solid }\end{array}$ & $\begin{array}{l}1.08 \mathrm{~L}(0.29 \mathrm{gal}) \\
0.03 \mathrm{~m}^{3}\left(0.883 \mathrm{ft}^{3}\right)\end{array}$ & $\begin{array}{l}4.3 \mathrm{~L}(1.16 \mathrm{gal}) \\
0.1 \mathrm{~m}^{3}\left(3.53 \mathrm{ft}^{3}\right)\end{array}$ & $\begin{array}{l}\text { Oils, solvents, and lead shielding con- } \\
\text { taminated with TRU materials. }\end{array}$ & $\begin{array}{l}\text { Solid material will be packaged in } \\
\text { drums for shipment to WIPP; liq- } \\
\text { uids will be processed on-site for } \\
\text { later off-site disposal as LLW }\end{array}$ \\
\hline $\begin{array}{l}\text { LLWa } \\
\text { Liquid } \\
\text { Solid }\end{array}$ & $\begin{array}{l}107 \mathrm{~L}(28.2 \mathrm{gal}) \\
35 \mathrm{~m}^{3}\left(1236 \mathrm{ft}^{3}\right)\end{array}$ & $\begin{array}{l}427 \mathrm{~L}(112.8 \mathrm{gal}) \\
140 \mathrm{~m}^{3}\left(4944 \mathrm{ft}^{3}\right)\end{array}$ & $\begin{array}{l}\text { Paper wipes, plastic, glassware, metal } \\
\text { containers, clad pieces, equipment }\end{array}$ & $\begin{array}{l}\text { Material will be prepared on-site } \\
\text { for shipment to off-site facility }\end{array}$ \\
\hline $\begin{array}{l}\text { Mixed LLW } \\
\text { Liquid } \\
\text { Solid }\end{array}$ & $\begin{array}{l}1.08 \mathrm{~L}(0.29 \mathrm{gal}) \\
0.35 \mathrm{~m}^{3}\left(12.36 \mathrm{ft}^{3}\right)\end{array}$ & $\begin{array}{l}4.3 \mathrm{~L}(1.16 \mathrm{gal}) \\
1.4 \mathrm{~m}^{3}\left(49.4 \mathrm{ft}^{3}\right)\end{array}$ & $\begin{array}{l}\text { Oils, solvents, and lead shielding con- } \\
\text { taminated with fission products } \\
\text { materials }\end{array}$ & $\begin{array}{l}\text { Material will be sorted and pre- } \\
\text { pared on-site for shipment to off- } \\
\text { site facilities }\end{array}$ \\
\hline $\begin{array}{l}\text { Hazardous } c \\
\text { Liquid } \\
\text { Solid }\end{array}$ & $\begin{array}{l}1.08 \mathrm{~L}(0.29 \mathrm{gal}) \\
0.35 \mathrm{~m}^{3}\left(12.36 \mathrm{ft}^{3}\right)\end{array}$ & $\begin{array}{l}4.3 \mathrm{~L}(1.16 \mathrm{gal}) \\
1.4 \mathrm{~m}^{3}\left(49.4 \mathrm{ft}^{3}\right)\end{array}$ & $\begin{array}{l}\text { Used oils, solvents, resins, glues, } \\
\text { containers }\end{array}$ & $\begin{array}{l}\text { Material will be sorted and pre- } \\
\text { pared on-site for shipment to off- } \\
\text { site facilities }\end{array}$ \\
\hline $\begin{array}{l}\text { Nonhazardous (sanitary) } \\
\text { Liquid } \\
\text { Solid }\end{array}$ & $\begin{array}{l}3.79 \times 10^{5} \mathrm{~L}\left(1.0 \times 10^{5} \mathrm{gal}\right) \\
50 \mathrm{~m}^{3}\left(1765 \mathrm{ft}^{3}\right)\end{array}$ & $\begin{array}{l}1.51 \times 10^{6} \mathrm{~L}\left(4 \times 10^{5} \mathrm{gal}\right) \\
130 \mathrm{~m}^{3}\left(4591 \mathrm{ft}^{3}\right)\end{array}$ & $\begin{array}{l}\text { Potable water, cleaning, paper, plastic, } \\
\text { metal containers, garbage }\end{array}$ & $\begin{array}{l}\text { Materials will be disposed of } \\
\text { through laboratory (on-site) non- } \\
\text { hazardous waste facility }\end{array}$ \\
\hline $\begin{array}{l}\text { Nonhazardous (other) } \\
\text { specific by waste } \\
\text { Liquid } \\
\text { Solid }\end{array}$ & $\begin{array}{l}4 \mathrm{~L}(1.06 \mathrm{gal}) \\
0.75 \mathrm{~m}^{3}\left(26.48 \mathrm{ft}^{3}\right)\end{array}$ & $\begin{array}{l}16 \mathrm{~L}(4.23 \mathrm{gal}) \\
3 \mathrm{~m}^{3}\left(106 \mathrm{ft}^{3}\right)\end{array}$ & $\begin{array}{l}\text { Chemical reagents, oils, cleaners, scrap } \\
\text { metal, wood, plastic }\end{array}$ & $\begin{array}{l}\text { Materials will be disposed through } \\
\text { laboratory (on-site) nonhazardous } \\
\text { waste facility. Scrap may be dis- } \\
\text { posed of through the laboratory to } \\
\text { off-site vendors }\end{array}$ \\
\hline
\end{tabular}

Note: Estimates are based on historical experience from other programs and current operations. The actual waste stream will be strongly dependent on the type and amount of work performed. The actual waste handling will depend on the laboratory facilities in operation at the time and the current disposal regulations. The final volumes of waste will be smaller depending on the treatment option (drying, compacting, burning).

$a_{L i q u i d} L L W$ is assumed to be $100 \%$ of the TRU.

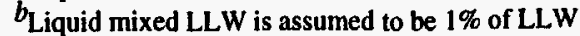

$c_{\text {Hazardous waste is assumed to be } 1 \% \text { of LLW. }}$ 
Table 34. Radiation doses to involved workers during the LA PIE [whole body committed effective dose equivalent (CEDE)]

Average annual dose to all involved workers at the facility, mrem 177

Maximum dose to an involved worker at the facility, mrem 347

Total number of involved workers

Note: Table numbers are averages over 1994, 1995, and 1996 for Building 3525 at ORNL. Values are from the radiation protection representative. It is assumed that the MOX PIE will encounter similar exposures.

Table 35. PIE estimates for EIS

For planning purposes assume 17 by 17 fuel bundle array Bundle length

Pellet size

Approximate density $\mathrm{UO}_{2}+\mathrm{PuO}_{2}$

Mass of pellet

Mass of pellet HM

Pellets per rod

Pellet mass per rod

HM per rod

Assume detailed PIE will involve ten rods per bundle and

ten bundles

Estimated samples per rod

Total samples

Assume one-third metal mounts

Assume one-third clad specimens

Assume one-third radiochemical specimens

Liquid waste per metal mount

Liquid waste per clad specimen

Liquid waste per radiochemical specimens

Total specimen liquid waste (TRU)

Solid waste per metal mount and all mounts

Solid waste per clad specimen and all clad specimens

Solid waste per radiochemical specimen and all specimens

Total specimen solid waste (TRU)

Assume two B-25 boxes of equipment

One-half equipment LLW

One-half equipment TRU

Assume one B- 25 box per month/48 months

$0.9 \mathrm{LLW}$ [personal protective equipment (PPE), wipes, scrap, etc.]

0.1 TRU

Total liquid TRU waste

Total solid TRU waste
289 rods total

$13.50 \mathrm{ft}$

0.37 -in. diam,

0.60 -in. length, and

0.06 -in. ${ }^{3}$ volume

$11.00 \mathrm{~g} / \mathrm{cm}^{3}$

$11.43 \mathrm{~g}$

$10.08 \mathrm{~g}$

270.00

$3087 \mathrm{~g}$

$2721 \mathrm{~g}$

100 rods to be cut up

10

1000

333

333

333

$0.5 \mathrm{~L} \quad 167 \mathrm{~L}$ total for metal mounts

$0.1 \mathrm{~L} \quad 33 \mathrm{~L}$ total for clad specimen

$1 \mathrm{~L} \quad 33 \mathrm{~L}$ total for radiochemical

$533 \mathrm{~L}$

$200 \mathrm{~cm}^{3} \quad 0.07 \mathrm{~m}^{3}$ total

$200 \mathrm{~cm}^{3} \quad 0.07 \mathrm{~m}^{3}$ total

$500 \mathrm{~cm}^{3} \quad 0.17 \mathrm{~m}^{3}$ total

$0.30 \mathrm{~m}^{3}$

$6 \mathrm{~m}^{3}$

$3 \mathrm{~m}^{3}$

$3 \mathrm{~m}^{3}$

$144 \mathrm{~m}^{3}$

$130 \mathrm{~m}^{3}$

$14 \mathrm{~m}^{3}$

$533 \mathrm{~L}$

$18 \mathrm{~m}^{3}$ 
Table 35. (continued)

Total mixed liquid TRU waste

$5 \mathrm{~L}$ (estimated as $1 \%$ of TRU)

Total mixed solid TRU waste

$0.18 \mathrm{~m}^{3}$ (estimated as $1 \%$ of TRU)

Total liquid LLW

Total solid LLW

Total mixed liquid LLW

Total mixed solid LIW

$533 \mathrm{~L}$ (estimated same as TRU)

$133 \mathrm{~m}^{3}$

$5 \mathrm{~L}$ (estimated as $1 \%$ of LLW)

$1 \mathrm{~m}^{3}$ (estimated as $1 \%$ of LLW)

Other waste streams

Liquid hazardous waste

$5 \mathrm{~L}$ (estimated as $1 \%$ of LLW)

Solid hazardous waste

$1 \mathrm{~m}^{3}$ (estimated as $1 \%$ of LLW)

Nonhazardous liquid waste

$533 \mathrm{~L}$ (estimated as $100 \%$ LLW)

Nonhazardous solid waste

Nonhazardous liquid other waste-chemicals

$133 \mathrm{~m}^{3}$ (estimated as $100 \%$ of LLW)

$5 \mathrm{~L}$ (estimated as $1 \%$

Nonhazardous solid other waste-scrap metal, one B-25 box of LLW)

$3 \mathrm{~m}^{3}$

Assume that bulk of the fuel rods and fuel bundle will be handled as spent nuclear fuel and sent to Idaho National Engineering and Environmental Laboratory 


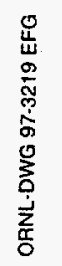

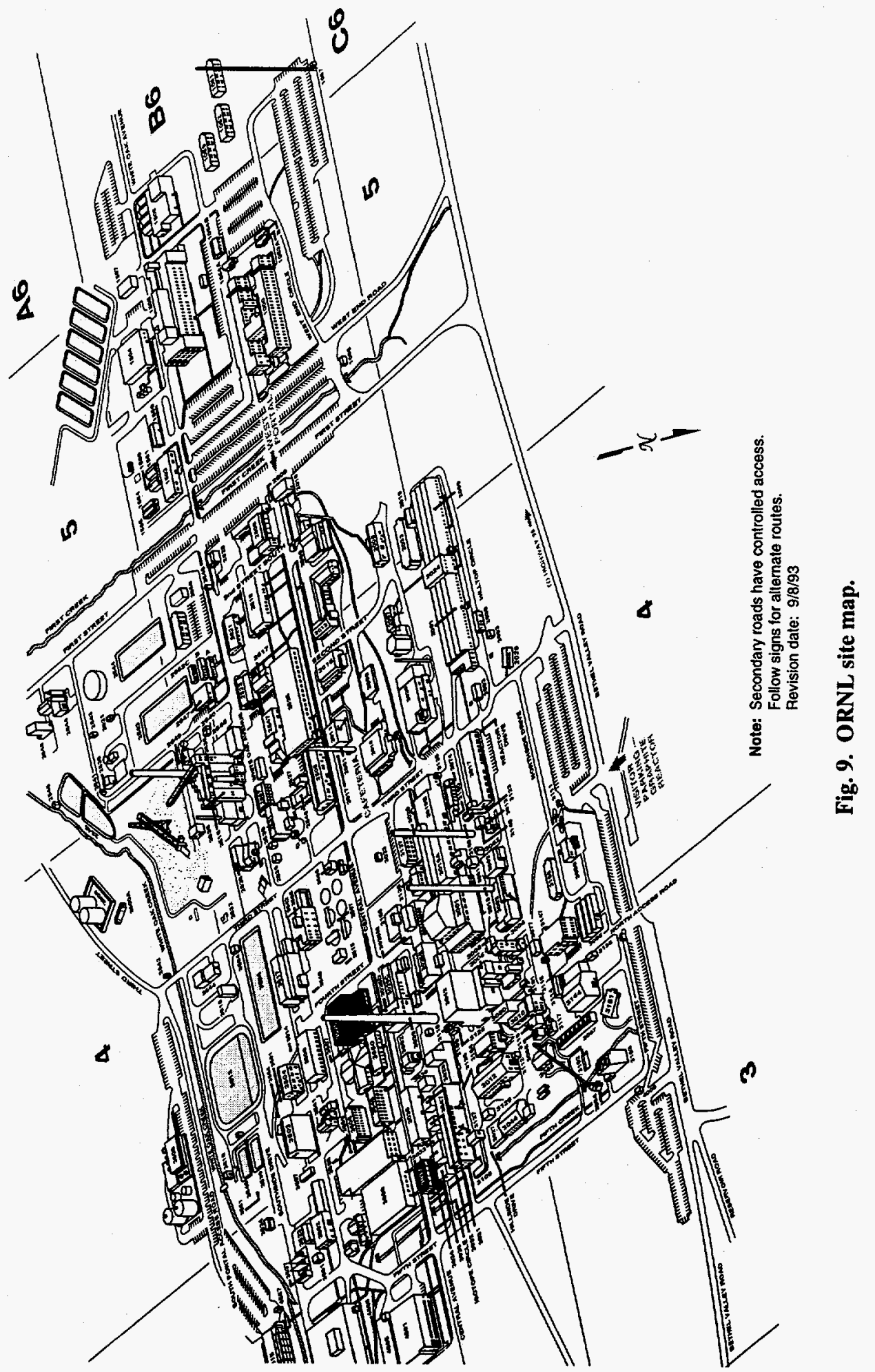


704 Fuel Manufacturing Facility (FMF)

752 Laboratory And Offica Building (L\& $O$ Building)

77 Radioactive Scrap And Waste Facility (RSWF)

775 ZPPR Workroom-Equipment Room

776 2PPR Rsactor Coll

785 Hot Fuel Examiration Facility (HFEF)

797 Radioacive Sodium Storage Facility (RSSF)

798 Radioactive Liquid Waste Treatmont Facilfy (RLWTF)

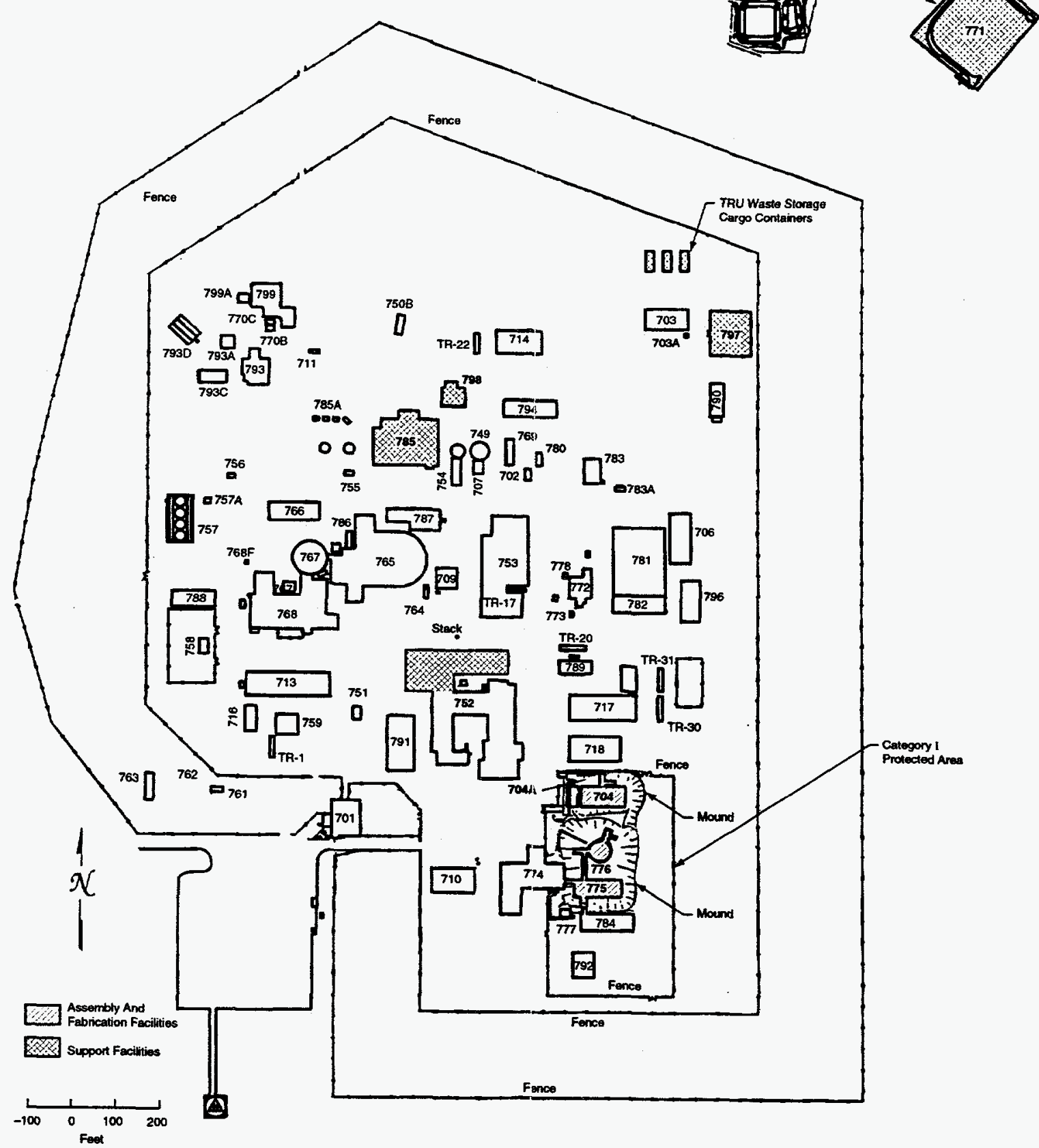

Fig. 10. ANL-W site map. 
Technical Reports Series No. 322; and the Guidebook on Destructive Examination of Water Reactor Fuel, IAEA Technical Reports Series No. 385.

In addition to materials testing, the segmented fuel may be used as a test subject for accident testing. The segment may be heated to high temperatures in a variety of atmospheres in a complex test apparatus and its releases measured. Other specialized methods also exist; irradiated material may be removed from one experiment and transferred to another in the hot cell for further irradiation.

The fuel rods in the MOX program will employ nondestructive examination as well as many of the destructive techniques. Normal practice is rather broad, and the actual techniques and items of interest will be determined before PIE and will depend on the program's knowledge and confidence level at the time.

\subsection{ANL-W}

The Hot Fuel Examination Facility (HFEF) is a hot-cell complex for the preparation and examination of irradiated experiments and the characterization and testing of waste forms from conditioning of spent fuel and waste. The HFEF is located on the ANL-W site, which is located in the south-west corner of INEEL. The HFEF facility is located on the north end of a double-fenced compound on the ANL-W site.

HFEF consists of two adjacent shielded hot cells (the main and decon cells), a shielded metallographic loading box, an unshielded Hot Repair Area (HRA) and a Waste Characterization Area (WCA). The building is a three-story structure with a basement support area. The building dimensions are $112 \mathrm{ft}$ wide by $154 \mathrm{ft}$ long with a gross floor area of $56,570 \mathrm{ft}^{2}$ and a gross volume of $1,337,200 \mathrm{ft}^{3}$.

The metallographic loading box is located outside the main cell in the metallograph room. This room is located on the north side of the building on the main floor and is separated from the main cell by an operating corridor.

The HRA and WCA are located in the high bay area. The area provides access to the ceiling penetrations in the main and decon cells as well as the HRA roof hatch. The high bay is also used as a staging area for the WCA.

Since the shutdown and defueling of the EBR-II reactor, HFEF has been used for many diverse programs. The primary program, since October 1994, has been the support of the EBR-II defueling and decommissioning. HFEF was responsible for receiving all of the fuel and blanket material from EBR-II and preparing the material for storage in the Radioactive Scrap and Waste Facility (RSWF).

In addition to the handling of the EBR-II fuel, HFEF is the examination facility for both the metal and ceramic waste form experiments from FCF. Cladding hulls from the conditioning of fuel in FCF need to be processed for disposal in a repository. The processing of the cladding hulls and the characterization of the waste form is being tested in HFEF. In addition, equipment is being installed and processes tested for the disposal of the plutonium and fission product waste from the conditioning of EBR-II fuel. The testing and characterization of the ceramic waste forms will be performed in HFEF.

HFEF is presently starting facility modification to accept commercial-sized fuel assemblies from the Watts Bar reactor. These assemblies (specifically, tritium production burnable absorber rods) are the initial assemblies being irradiated as part of DOE's commercial LWR tritium production evaluation. All of the examination equipment in the cell and the cask handling systems are being modified to handle commercialsized casks and fuel rods for examination. These modifications will be complete in mid-1999.

Some of the stainless steel reflector subassemblies used in EBR-II have experienced neutron exposure since the reactor was started in the early 1960s. The neutron damage to these steels is of interest to the commercial power industry, especially in Japan. Two programs are in place where the stainless steels are being prepared for testing of the neutron damage. These programs involve the cutting and preparation of samples for testing at other laboratories.

The north neutron radiography station has been modified to house a neutron generator for neutron assay of waste. Testing is presently being done on developing neutron assay techniques for the waste from the FCF.

In support of the National Spent Fuel Program, HFEF is presently engaged in the examination of degraded EBR-II fuels that have been stored in water pools at the ICPP. The fuel was shipped to ICPP in sealed containers. During the 15 to 20 years of storage in the water basin at ICPP, some of the containers 
have leaked causing the fuel to breach. The characterization and examination of the degraded fuel at the HFEF will determine the chemical condition of the fuel as well as the mechanism for breaching. This program will be ongoing during the next 2 years.

\subsubsection{Main Cell}

The HFEF main cell is $70 \mathrm{ft}$ long by $30 \mathrm{ft}$ wide by $25 \mathrm{ft}$ high and has an argon gas atmosphere. The argon gas in the cell is maintained as pure as possible; however, a small amount of moisture is needed to help lubricate and cool the brushes on the electric motors used in cell. Because of this, the moisture and oxygen levels are maintained about $40 \mathrm{ppm}$. The maximum oxygen and moisture levels are kept below 100 $\mathrm{ppm}$. The cell atmosphere is maintained at these levels using a purification system.

An 8-ft deep space that is located beneath removalule flooring and covers the entire width of the cell is used for storage of fuel elements during their examination. Also located in this space are the bases of the examination stages, ducts and filters for the main cell cooling system, and pits for the storage of radioactive materials. A total of ten 1-ft diam by $10-\mathrm{ft}$ long storage pipes are located in the center aisle of the cell for storage of Experimental Breeder Reactor-II (EBR-II) subassemblies. These pits are equipped with forced argon cooling for decay heat removal of their contents.

In addition to the subfloor space, two 3 - $\mathrm{ft}$ diam pits extend $30 \mathrm{ft}$ below the level of the removable floor at workstations $8 \mathrm{M}$ and $9 \mathrm{M}$ (south-east corner of the cell). These pits are used for storing and handling of long items such as long test loops. Each pil has a corresponding roof penetration so long items can be transferred into the cell and placed in a pit.

The main cell is serviced by two electro-mechanical manipulators (EMMs) rated for $750 \mathrm{lb}$ and two 5-ton bridge cranes. The maximum lift for an EMM in the main cell is $11 \mathrm{ft} 8 \mathrm{in}$. The maximum lift for a crane in the cell is $19 \mathrm{ft} 11-5 / 8$ in.

There are 15 workstations in the main cell. Each workstation is equipped with two master/slave (MS) manipulators. Most of the MS manipulators are Central Research Laboratory (CRL) Model J's rated for a 20-lb vertical lift. Five of the workstations are equipped with CRL System 50 manipulators rated for a 50-lb vertical lift.

\subsubsection{Decon Cell}

The air-filled decon cell is located adjacent to the west end of the main cell and is $30 \mathrm{ft}$ wide by $20 \mathrm{ft}$ long by $25 \mathrm{ft}$ high. There is no subfloor space in the decon cell; however, three 15.5 -in. diam by $10 \mathrm{ft}$ deep pits are located at workstation 3D. Another similar pit is located at workstation $4 \mathrm{D}$, and a $3-\mathrm{ft}$ diam by $30-\mathrm{ft}$ deep pit is located at workstation 5D.

The decon cell is equipped with an $8-\mathrm{ft}$ wide by $7-\mathrm{ft}$ deep by $11-\mathrm{ft}$ high spray chamber for decontaminating equipment and nonfissile material using a manipulator-held wand. The wand can be used for spraying either water or steam. A chemical addition tank is connected to the water feed line for the addition of decontamination solutions to the water stream. Items being decontaminated are positioned on a 5-ton turntable inside the chamber so that they can be rotated. Both the roof and back side of the spray chamber can be opened remotely so items being decontaminated can be placed inside the chamber.

Material handling inside the decon cell is performed with one 750-lb EMM and one 5-ton crane. The maximum lifting height of the EMM is $11 \mathrm{ft} 8 \mathrm{in}$. and that of the crane is $19 \mathrm{ft} 11 \mathrm{in}$. In addition to the EMM and crane, the cell is equipped with six sets of MS manipulators. Most of the workstations are equipped with one CRL model E MS, rated for a 20 -lb vertical lift, and one CRL model F MS, rated for a 100 -lb vertical lift.

Two pneumatic transfer stations are inside the clecon cell. One station originates at station 4D and runs to the Fuel Conditioning Facility (FCF). The other station originates inside the spray chamber and runs to the radiation safety office (HP office). The pneumatic transfer station that runs to FCF is used for sending small irradiated samples to FCF then on to the Analytical Laboratory (AL) for analysis. 


\subsubsection{Metallographic Loading Box}

The metallographic loading cell is a shielded, gas-tight cell with inside dimensions of $8 \mathrm{ft}$ wide by $6 \mathrm{ft}$ deep by $5 \mathrm{ft}$ high. The cell is provided to accommodate a Leitz metallograph and a scanning electron microscope (SEM) for performing detailed examination of metallurgical samples. The shielding walls (except the front wall) are constructed of 8-in.-thick lead brick. The front wall is 15 -in. thick and is constructed of three 5-in.-thick steel plates. The front wall has a lead-glass window for viewing and two CRL Model L MS manipulators.

\subsubsection{HRA}

The HRA is a series of rooms located directly above the decon cell and west end of the main cell in the high bay area. The outside dimensions of the HRA are $45 \mathrm{ft}$ by $70 \mathrm{ft}$. The primary purpose of the HRA is to perform contact maintenance on cell equipment. The HRA is divided into 12 areas:

1. Hot Repair Room (HRR)

2. Suspect Repair Room

3. Equipment Access Room (Cart Room)

4. Isolation Area Room

5. Survey Room

6. Health Physics (HP) Office

7. Unsealed Slave Repair Room

8. Bagout Room

9. Sealed Slave Arm Repair Glove Box Room

10. Stepout Area Room

11. Glovewall Room

12. Ancillary Area Room

Most of the rooms in the HRA are specific-purpose rooms used for the repair of MS manipulators and other facility-specific equipment. The HRR can be used for the transfer of equipment and materials between the decon cell and HRA. Both the HRR and Suspect Repair Room are serviced by a 5-ton bridge crane. The crane uses a removable rotating hook for remote positioning of the hook. With the rotating hook removed, the maximum lift inside the repair rooms is $13 \mathrm{ft} 6 \mathrm{in}$. With the hook in place the maximum lift inside the HRR is $12 \mathrm{ft} 1 \mathrm{in}$. The drum on the crane is provided with enough cable for a $50-\mathrm{ft}$ lift so that it can be used for raising and lowering equipment into the decon cell.

A $10 \mathrm{ft}^{2}$ roof hatch is located in the ceiling of the HRR, directly above the decon cell roof hatch. The hatch is provided with a 114-in. diam bagging ring so it can be used for the transfer of equipment and material directly from the high bay area into the decon cell.

The equipment access room (cart room) is designed to be a lock in the transfer path between the high bay area and the HRR. The room is $8 \mathrm{ft}^{2}$ by $20 \mathrm{ft}$ high and has a $6 \mathrm{ft} 4$ in. ${ }^{2}$ hatch in the ceiling. The room is generally maintained clean so equipment and materials can be transferred from the high bay area to the room through the hatch. A 5-ton equipment cart runs between the cart room and the HRR for moving the equipment and materials between the two rooms.

\subsubsection{WCA}

The WCA is used for the characterization and sampling of contact-handled transuranic waste (CH TRU) for the Waste Isolation Pilot Plant (WIPP) performance assessment. The facility consists of the Preparation Room, Transfer Room, Waste Characterization Chamber (WCC), Sludge Preparation glove box, Operations Room and the Equipment Room.

The Preparation Room (PR) is used as a staging area for waste going into and out of the WCC. Waste drums awaiting characterization in the WCC are stored in the PR, and waste that has been characterized and is awaiting shipment back to the Radioactive Waste Management Complex (RWMC) is also stored in the room. Personnel access to the PR is through a vestibule on the south-east corner of the room. Waste 
drums and equipment are brought into the room using the high bay crane through a $10-\mathrm{ft}$ high by $8 \mathrm{ft}$ wide equipment door on the south wall. High bay crane hook access to the room is through a $2-\mathrm{ft}$ wide by 17 -ft-long rollup door on the vertical wall and ceiling above the equipment door. Waste drums and equipment are handled inside the PR by a cantilever-style jib crane rated for a $6000 \mathrm{lb} \mathrm{SWL}$. The crane has a lift height of $12 \mathrm{ft} 8 \mathrm{in}$.

The Transfer Room (TR) is where the waste drums are mated with the WCC. Access to the room is through double doors from the PR. The drums are moved into and out of the TR using a drum cart rated at $2,000 \mathrm{lb} \mathrm{SWL}$. In addition to moving the drums into and out of the room, the cart is used to raise and lower the drums to the drum ports on the bottom of the WCC. Once the drums are bagged to the WCC, they are held in position in the drum ports by turnbuckles which fasten between the bottom of the WCC and an adapter plate under the drums.

The WCC is a 16-ft long by 8 - $\mathrm{ft}$ high by 8 -ft deep glove box used for characterization of CH TRU wastes. The WCC is equipped with shielded viewing windows for personnel protection from low-level gamma and beta radiation. Each window is a three-piece assembly consisting of an inner safety glass, a lexan plate, and leaded glass on the exterior. There are two 200-1b dual Titan 7F manipulators and a 1,500-lb articulated jib crane for handling the waste and equipment inside the glove box. A core boring machine is mounted to the top of the glove box over the west drum port and is used for taking samples from sludge drums. There are 28 glove ports on the WCC. These glove ports are located at various heights for waste handling and equipment repair. A transfer port is located on the east end of the WCC for transferring sludge samples to the Sample Preparation glove box.

The Equipment Room (ER) is located above the WCC and houses the filters, piping, and blowers for the WCC ventilation system. In addition to the ventilation equipment, the ER has a repair glove box for repair of the equipment inside the WCC. The glove box is connected to the west end of the WCC through a transfer tunnel. Equipment is raised and lowered from the repair glove box by a hoist inside the glove box.

The Operations Room (OR) is the area around the WCC and Sample Preparation and Transfer glove boxes. The room provides a mezzanine on the west end of the WCC for the Waste Data Acquisition System (WDAS). The WDAS is used for video taping and audio dubbing of the waste handling operations. A computer controlled switcher is used for switching video sources and recorders. The computer control system for the gas sampling system is mounted on the south end of the WDAS.

In addition to the WDAS, the OR provides monitoring and alarm panels for monitoring the status of the WCA. The panel provides flow and pressure information on the WCC, radiation alarms, breathing air alarms, and fire alarms for the inside of the WCC.

The sludge preparation (SP) glove box is used for preparing sludge samples for shipment to the Idaho Chemical Processing Plant (ICPP) to be analyzed for halogenated VOCs, nonhalogenated VOCs, RCRA heavy metals, and radioassay. After the sludge has been cored, the core section is transferred to the SP glove box where the samples are taken at various locations along the core section. As each sample is taken, it is weighed, placed in a labeled vial, and shipped to ICPP in a Type A container. Some experimentation is being done on real time analysis of the samples using $\mathrm{X}$-ray florescence. The testing of the equipment has not been completed.

\subsection{ORNL}

The Irradiated Fuels Examination Laboratory (IFEL), Building 3525, has a long history of fuel research and examination. It is part of ORNL and is located in Bethel Valley and Melton Valley, approximately 8 miles southwest of the city of Oak Ridge, Tennessee. For three decades this facility has handled a wide variety of fuels including aluminum clad research reactor fuel, both stainless- and zircaloyclad LWR fuel, coated-particle gas cooled reactor fuel, and numerous one of a kind fuel test specimens. In addition, the facility has also done iridium isotope processing and irradiated capsule disassembly.

The IFEL contains a large horseshoe-shaped array of hot cells which are divided into three work areas (Fig. 11). The hot cells are constructed of 3-ft-thick concrete walls with oil-filled, lead-glass viewing windows. The inside of surfaces of the cell bank are lined with stainless steel to provide containment of particulate matter and to facilitate decontamination. Special penetrations are provided for the sealed entry of services such as instrument lines, lights, and electrical power. A pair of manipulators are located at each 


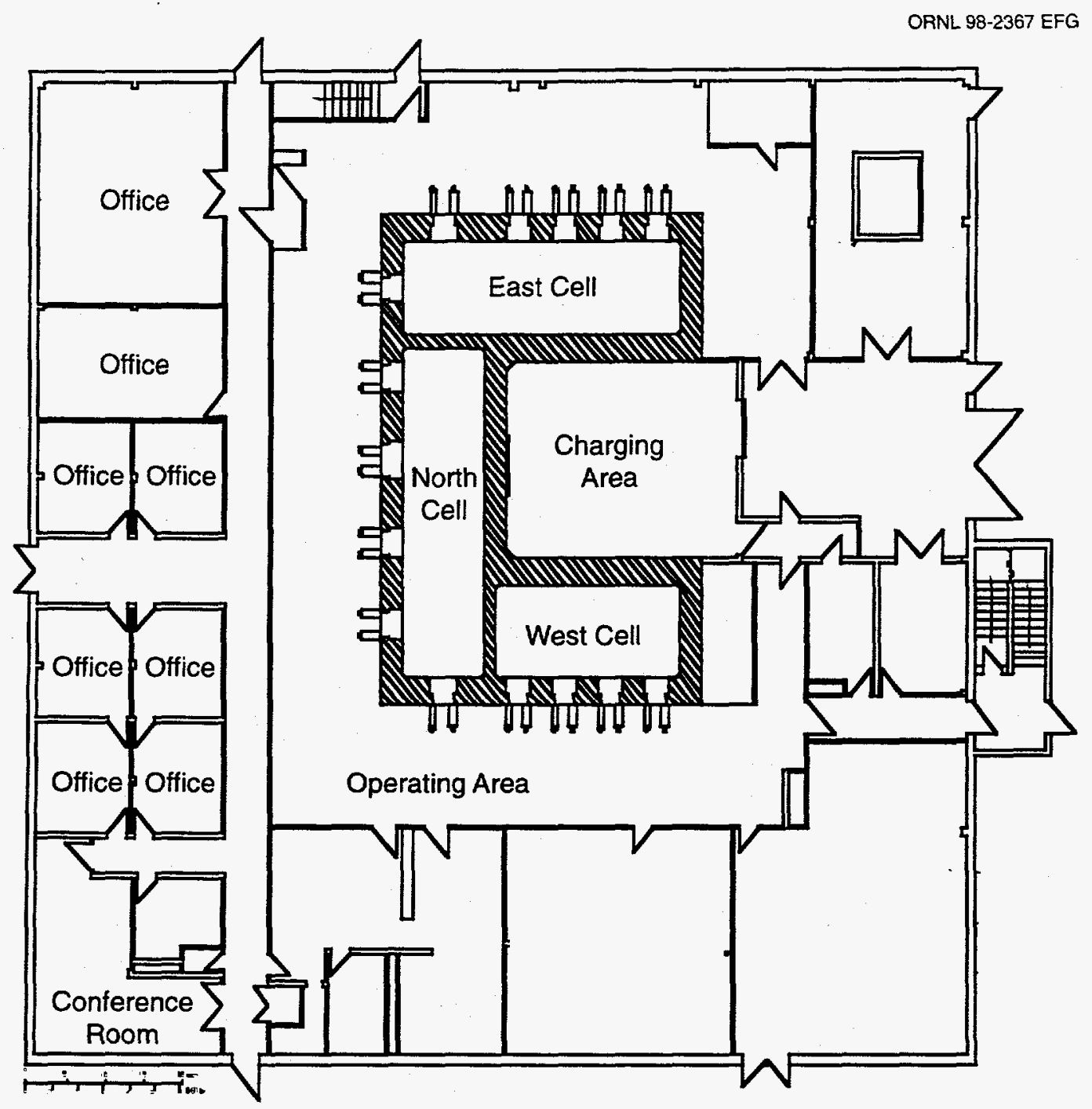

Fig. 11. Building 3525 layout.

of 15 window stations for remote cell operations, and periscopes allow for magnified views of in-cell objects. Heavy objects within each cell bank can be moved by electromechanical manipulators or a 3-ton crane. Fuel materials enter and leave the cells through three shielded transfer stations provided at the rear face of the North cell. Two small diameter (6.5 and 14.5 in.) horizontal transfer stations are used for small objects (less than $8 \mathrm{ft}$ in length). Items up to $4 \times 4 \times 6 \mathrm{ft}$ in size can be transferred through the shielded airlock door system.

The remainder of the laboratory outside the hot cell complex is subdivided into: (1) the charging area; (2) the equipment maintenance air lock areas; (3) the operating area; (4) the truck unloading area, the change room, and a work room; and (5) the rooms housing supporting mechanical equipment. Located on the east side of the truck unloading area is a small laboratory which houses the Core Conduction Cooldown Test Facility (CCCTF). The CCCTF is used to test radioactive samples under controlled thermal conditions while monitoring the samples to determine the release rate of radioactive materials.

A decontamination cell and storage cell, located on the second floor of the building, are connected via hatches to the cells below. A maintenance area incorporating glove box facilities for servicing equipment items adjoins the decontamination cell. Sliding doors separate the decontamination cell, storage cell, and glove maintenance room; a remote crane system provides for retrieval of equipment into and transfer of items between these second-floor facilities. Equipment may be transferred between cells through the 
second-floor pathway. An upper level of the second floor houses ventilation system ducts, control valves, high efficiency particulate air filters, heat exchangers, and air inlets for the equipment storage area, the decontamination area, and the glove maintenance area.

Gases and particulates exhausted from the cell complex are completely contained and shielded until subjected to sufficient filtration to ensure safe stack disposal. The cell air is maintained at negative pressure with respect to the operating areas to ensure confinement. Liquid effluent from the hot cells is handled in a batch mode for disposal to the ORNL low-level liquid waste system.

A variety of shears, machine tools, and cutoff saws are available within the cell for the gross handling and preparation of fuel specimens. The facility has experience in the handling and cutting of a wide variety of capsule and clad materials such as Inconel, stainless steel, zircaloy, aluminum matrix, and graphite-based materials. A gamma scanner is available for the nonclestructive examination of moderate-length fuel rods and individual specimens. Metrology equipment such as mass scales and dimensional tools are routinely used and available.

Metallographic equipment including small cutoff saws, polishers, and a shielded metallograph are available for the preparation, handling, and examination of both fuel specimens and clad material. The facility has prepared samples of oxide fuels, carbide fuels, and metal matrix fuels.

Building 3525 also has other facilities outside the main bank of cells: a scanning electron microscope that can handle radioactive specimens, additional gamma analysis and dosimetry equipment for both centimeter-sized and submillimeter-sized samples, and a small stand-alone hot cell with specialized equipment for the handling and analysis of coated-particle fuels.

Radiochemical specimens can be prepared within the facility and delivered to other ORNL laboratories for detailed analysis. ORNL also has extensive computational abilities that can be used to process the hot cell data for comparison with fuel performance models.

PIE capabilities of the IFEL have provided general support to fuels program, fuel characterization, and analysis of candidate irradiated fuel. Typically, the fuel is received at the IFEL, dimensionally inspected, visually examined for defects, and gamma scanned for internal fuel gaps or cracks along with gross fission product migration. The fuel can then be removed from its casing or clad and fuel and clad specimens prepared for metallographic examination, gamma counting, and radiochemical analysis. Actinide and fission product inventories can be determined along with burnup and radial isotope distributions within the fuel. The mechanical properties of the specimens can also be investigated to determine the state of the fuel and/or clad materials. All work is typically done with proper procedures and documentation after concurrence is obtained from the program participants.

Recent work includes extensive support for the Gas Turbine Modular High-Temperature Gas-Cooled Reactor (GT-MHR) program, the New Production Reactor (NPR), a cooperative gas-cooled reactor agreement with Japan, and handling of legacy fuel under the National Spent Fuel program. Personnel are available with experience in a wide variety of fuel PIE programs and analysis techniques along with the detailed reporting and quality control requirements for nuclear programs. The Metals and Ceramics (M\&C) division contains a wealth of experience in fuel fabrication, metal and ceramic material behavior, irradiated material behavior, and material testing. Ongoing programs at ORNL maintain experience in hot cell techniques and analysis. In addition, academic and industrial consultants are available to meet special program needs and to conduct reviews. 


\section{REFERENCES}

1. U.S. Department of Energy, Storage and Disposition of Weapons-Usable Fissile Materials Final Programmatic Environmental Impact Statement, Vol. 1, Chap. 3, DOE/EIS-0229, December 1996.

2. Los Alamos National Laboratory, Response to the Surplus Plutonium Disposition Environmental Impact Statement Data Call for a Mixed Oxide Fuel Fabrication Facility Located at Pantex Plant, LA-UR97-2067, Rev. 3, June 22, 1998.

3. V. S. White, Initial Data Report and Response to the Surplus Plutonium Disposition Environmental Impact Statement Data Call for the UO 2 Supply, ORNL/TM-13466, Lockheed Martin Energy Research Corporation, Oak Ridge National Laboratory, November 1997.

4. Shearon Harris Nuclear Power Plant Technical Specifications, Sect. 3.8.

5. U.S. Department of Energy, Airborne Release Fractions/Rates and Respirable Fractions for Nonreactor Nuclear Facilities, DOE-HDBK-3010-94, Vols. I and II, December 1994.

6. Browne and Firestone, Table of Radioactive Isotopes, V. S. Shirley, ed., John Wiley and Sons, 1986.

7. U.S. Department of Energy, Criteria for Preparing and Packaging Plutonium Metals and Oxides for Long-Term Storage, DOE-STD-3013-96, September 1996.

8. DOE Order 420.1, Sect. 4.3, Nuclear Criticality Safety.

9. 40 CFR 302.4, Table 302.4, List of Hazardous Substances and Reportable Quantities.

10. W. R. Stratton, A Review of Criticality Accidents, DOE/NCT-04, March 1989. 
Page Intentionally Blank 
Appendix A-LA FUEL BUNDLE FABRICATION

A-1 
Page Intentionally Blank 
$\mathrm{PuO}_{2}$

\begin{tabular}{|c|}
\hline SST Shipment Receipt \\
\hline$i$ \\
\hline Shipment Verification \\
\hline$t$ \\
\hline Product Vault Storage \\
\hline$t$ \\
\hline Ship to Fabrication Facility \\
\hline+1 \\
\hline Open Cans \\
\hline 7 \\
\hline Inspection \\
\hline Assay \\
\hline Chemistry \\
\hline Particle Autributes \\
\hline 1 \\
\hline Disposition \\
\hline$t$ \\
\hline Plutonium Production Storage \\
\hline
\end{tabular}

Depleted $\mathrm{UO}_{2}$

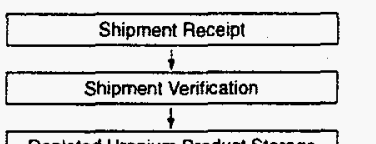

Depleted Uranium Product Storage $t$ Open Cans

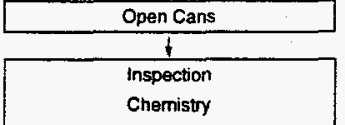

Particle Attributes

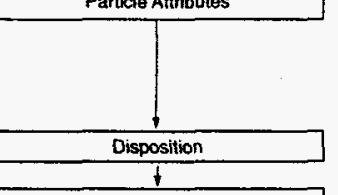

Depleted Uranium Production Storage

Hard Serap Recycle

Depleted Uranium/Plutonium

(Up To 10\% Ot Batch Makeup)

From Sintered Pellet Scrap

$\downarrow$

Weigh Storage

Crush (Jaw Crusher)

Crush (Jaw

Grind (Ball Mill)

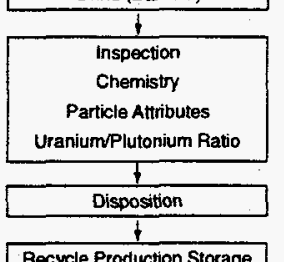

(30\% Plutonium) Powder

DispenseMeigh
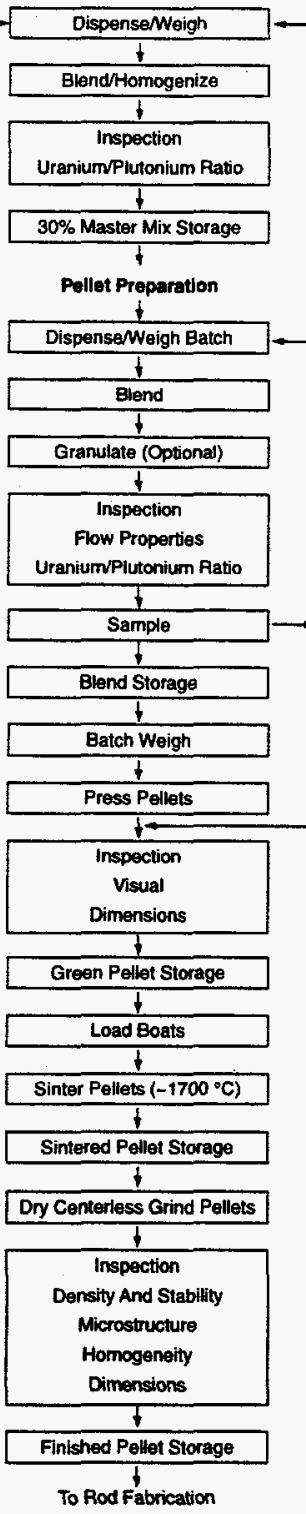

Fig. A.1. LA MOX fuel pellet flow sheet outline. 


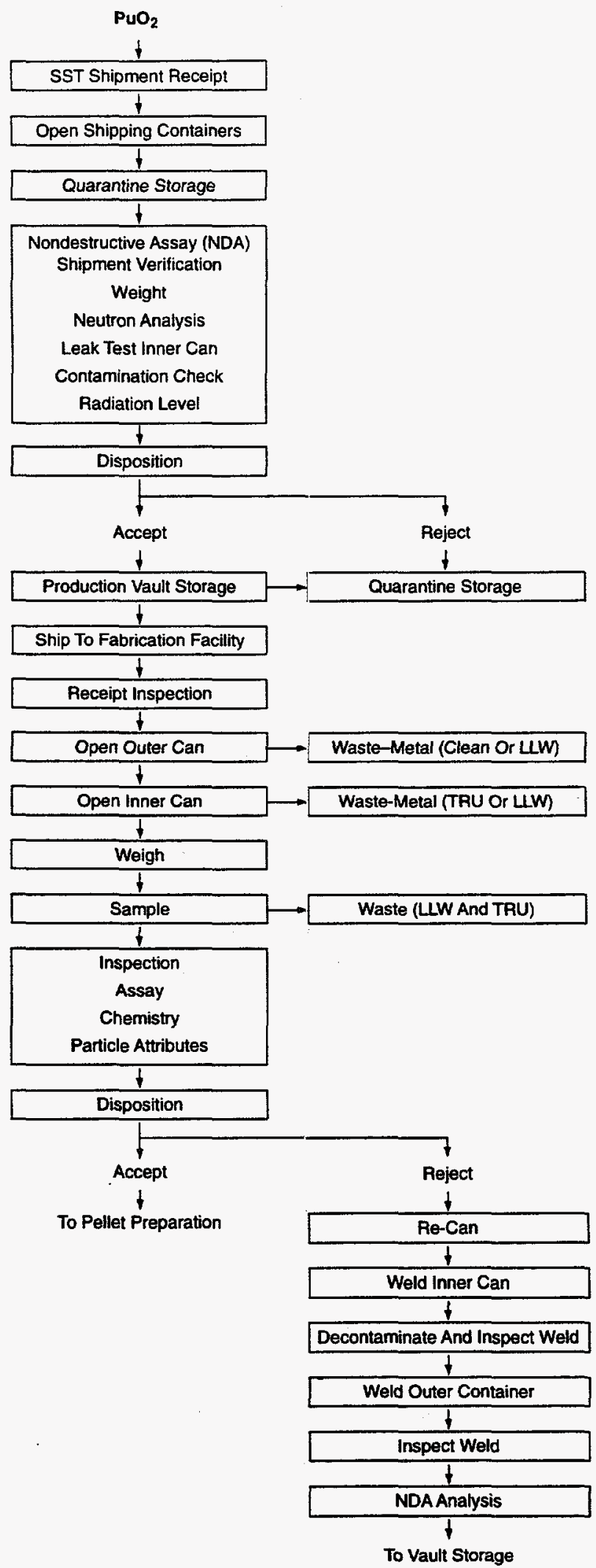

Fig. A.2. LA MOX fuel $\mathrm{PuO}_{2}$ powder receipt and storage. 

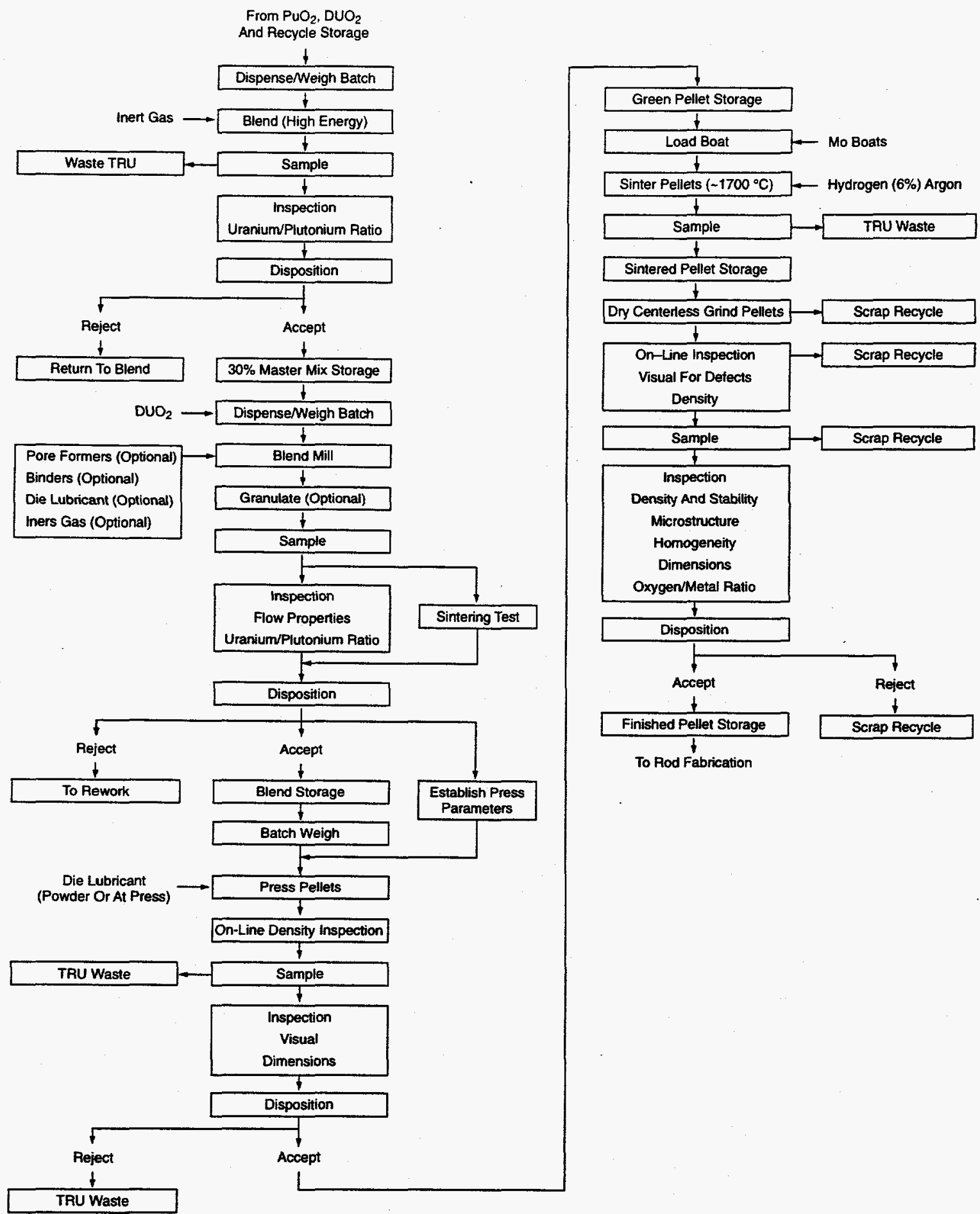

Fig. A.3. Detailed flow sheet of LA pellet fabrication. 


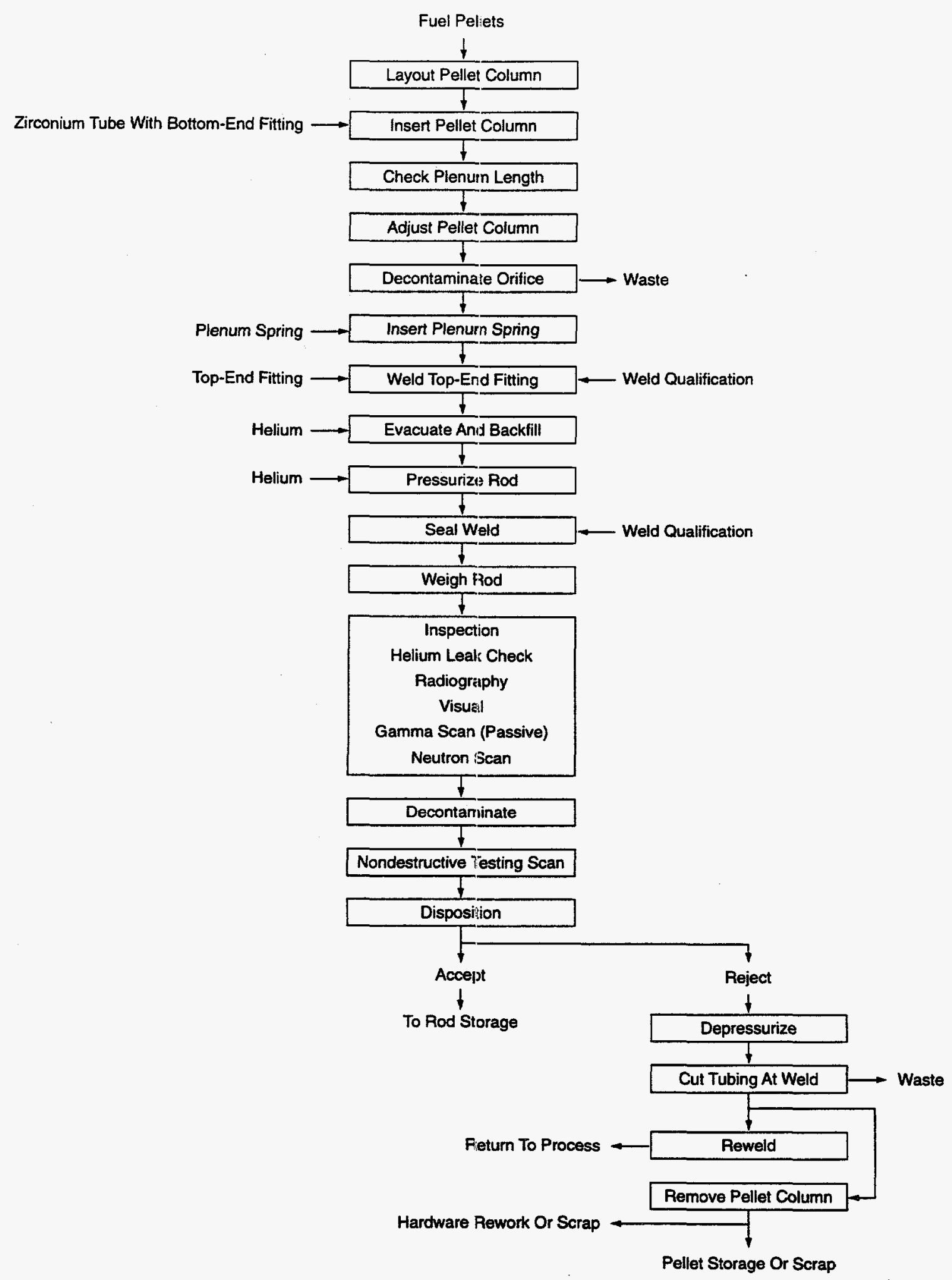

Fig. A.4. Detailed flow sheet of LA rod fabrication. 


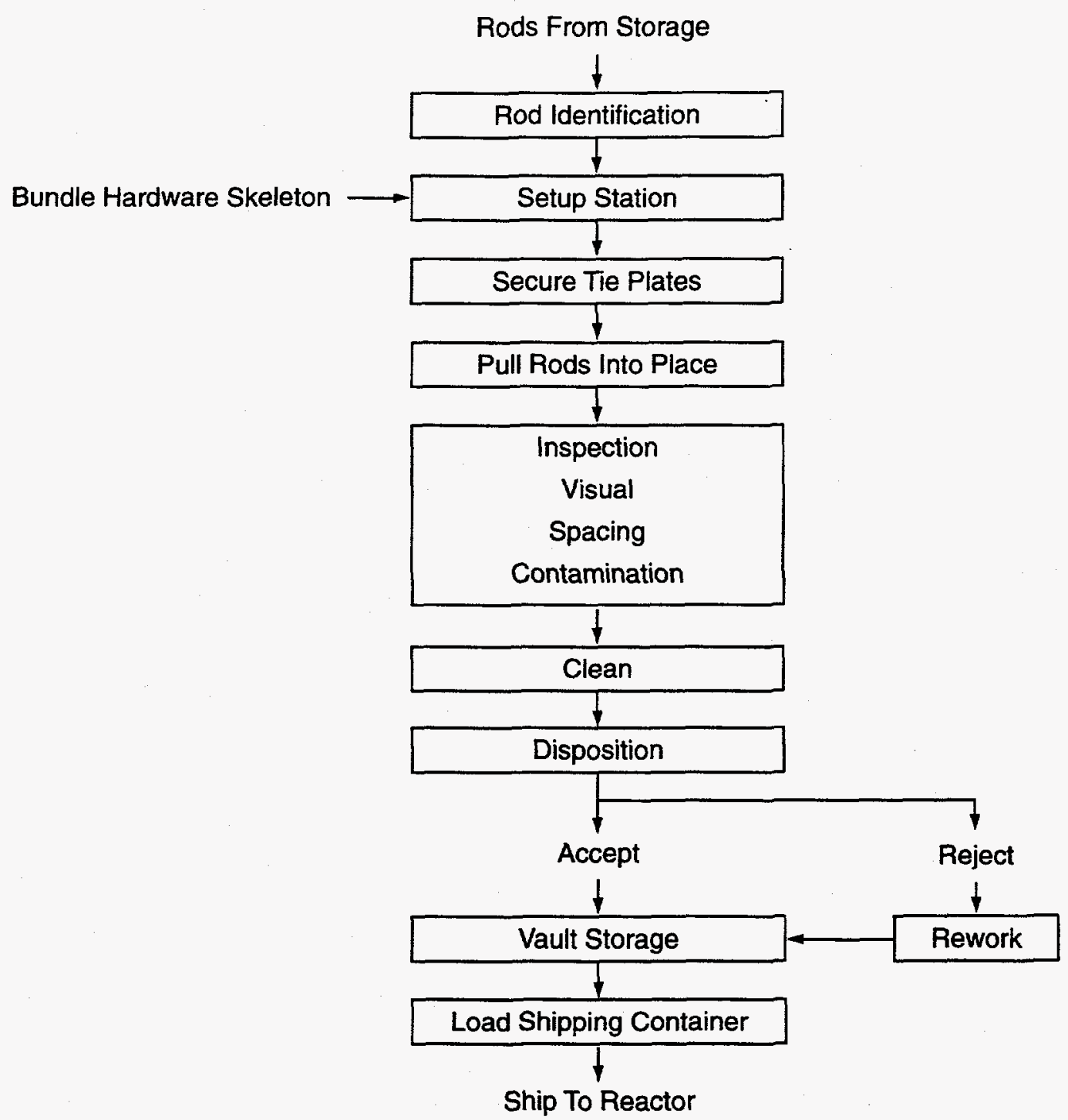

Fig. A.5. Detailed flow sheet of LA bundle assembly (LWR). 


\section{Page Intentionally Blank}


Appendix B-LA EIS DATA REPORT ASSUMPTIONS 
Page Intentionally Blank

B-? 
Table B.1. Assumptions used for the LA EIS data reports

1. Material and process requirements are based on producing PWR fuel.

2. $\mathrm{PuO}_{2}$ powder will meet the ASTM C 757-90 specification as received.

3. Depleted $\mathrm{UO}_{2}$ powder will meet the ASTM specification as received.

4. Depleted $\mathrm{UO}_{2}$ (no $\mathrm{PuO}_{2}$ ) will be used to perform all system shakedown tests before introducing plutonium.

5. Table 3 is in terms of $\mathrm{HM}$. The factor for converting $\mathrm{PuO}_{2}$ and depleted $\mathrm{UO}_{2}$ to $\mathrm{HM}$ is $88 \%$.

6. All waste plutonium will be canned and sent to the Immobilization Program for final disposition.

7. All plutonium scrap will be recycled using a dry process.

8. All liquid wastes generated are ancillary to the base process (i.e., laundry, mop water, etc.)

9. Sintering furnaces will stay at temperature during the entire 3-year mission and 1-year startup.

10. Sintering furnaces will be purged with a mixture of argon and $6 \%$ hydrogen at a rate of $10 \mathrm{~L} / \mathrm{min}$.

11. Powder glove boxes will be purged with nitrogen to reduce the potential for oxidizing $\mathrm{UO}_{2}$.

12. All calculated numbers have a precision of no more than two significant figures.

13. The facility will be built on an existing DOE site with a minimum of $4500 \mathrm{ft}^{2}$ available space $\left(3000 \mathrm{ft}^{2}\right.$ for MOX rod processing, $1000 \mathrm{ft}^{2}$ for bundling activities, and $500 \mathrm{ft}^{2}$ for fuel bundle storage).

14. The site will have an existing infrastructure in place to accept the LA mission.

15. Personnel will be required to support a process capacity of $\sim 2 \mathrm{MT} \mathrm{HM}$ per year.

16. Personnel involved in SNM operations must work in pairs and follow specific safety precautions detailed by the site.

17. Personnel must attend required site training. A staffing requirement for training purposes has been included in this estimate.

18. Space will be allocated for safe secure transports (SSTs) carrying plutonium and transportation for uranium so that loading can be accomplished on a follow-up operating shift if the transport arrives near or following the close of standard business.

19. As with the MOX fuel fabrication facility estimate, the staffing requirements assume that $-20 \%$ of the employee's time will be taken through training, vacation, personal leave, or illness. Even though employees cannot necessarily transition from one position to another, a contingency was added to account for nonproductive time.

20. Homogenization of the $\mathrm{PuO}_{2}$ powder will be done at the LA fuel fabrication facility, as will gallium removal operations. 
Page Intentionally Blank 
SRS RESPONSE TO THE SUPPLEMENTAL

LEAD TEST ASSEMBLY EIS DATA CALL 
Page Intentionally Blank 


\title{
SRS RESPONSE TO THE SUPPLEMENTAL LEAD TEST ASSEMBLY EIS DATA CALL
}

\author{
1. GENERAL SITE DATA NEEDS
}

No response was required.

\section{LOCATION-SPECIFIC DATA NEEDS}

\subsection{GENERAL FACILITIES INFORMATION NEEDS}

The facilities proposed for use in the lead assembly (LA) program (both options) are currently operating to support other programs and are under consideration for a number of future missions. National Environmental Policy Act (NEPA) coverage of current and proposed activities is provided by several environmental impact statements (EISs):

- Interim Management of Nuclear Materials Environmental Impact Statement (DOE/EIS-0220)

- Storage and Disposition of Weapons-Usable Fissile Materials Final Programmatic Environmental Impact Statements (DOE/EIS-0229)

- Stockpile Stewardship and Management Programmatic Environmental Impact Statement (DOE/EIS0236)

- Environmental Impact Statement on the Management of Certain Plutonium Residues and Scrub Alloy Stored at the Rocky Flats Environmental Technology Site (DOE/EIS-0277)

- Disposition of Surplus Highly Enriched Uranium Environmental Impact Statement (DOE/EIS-0240)

- Management of Aluminum Clad SNF at the SRS Environmental Impact Statement

The proposed LA program can be conducted independently of other current and proposed actions in $221-\mathrm{H}$. The cumulative impact of this program with other potential activities should be analyzed as part of this EIS.

The Westinghouse Savannah River Company (WSRC) Nuclear Material Stabilization and Storage (NMS\&S) Division employs 1460 people to manage two separation areas. Those directly concerned with day-to-day activities of the 221-H Canyon building are as follows: Operations-250, Facility Maintenance-65, and Engineering-70.

Others are engaged in program management, long-range planning, quality assurance, and technical support of the overall NMS\&S effort.

Table 1 [reproduced from the Interim Management of Nuclear Materials EIS (DOE/EIS-0220)] lists maximum and average individual doses and collective doses for the Savannah River Site (SRS). This period is representative of full operation of the facility. More recent data are less meaningful because they represent a standby period.

Radioactive emission monitoring is continuously performed on the 221- $\mathrm{H}$ main stack. Data from 1994 through 1997 (year-to-date) are attached (Attachment A). Note that the majority of these data are from a period of ${ }^{238} \mathrm{Pu}$ processing and may not be valid as a representation of future baseline emissions.

Nonradioactive chemical emissions are not monitored at the facility stack. The site uses a system of calculated maximum values for various operations. The current spent nuclear fuel (SNF) EIS is using theoretical maximum values of nonradioactive emissions from the 221-H stack (see Table 2).

A map is attached (Attachment B) showing the network of 35 air-surveillance stations maintained by SRS on the site and at locations up to 100 miles away. The South Carolina Department of Health and Environmental Control (SCDHEC) also maintains a system of ambient air quality monitoring stations, three of which (Jackson, Beech Island, and Barnwell) are in the vicinity of the site.

SRS wind rose information is attached (Attachment C). 
Table 1. SRS annual individual and collective radiation doses

\begin{tabular}{|c|c|c|c|}
\hline \multirow[t]{2}{*}{ Year } & \multicolumn{2}{|c|}{$\begin{array}{c}\text { Individual dose } \\
\text { (rem) }\end{array}$} & \multirow{2}{*}{$\begin{array}{l}\text { Site collective dose } \\
\text { (person-rem) }\end{array}$} \\
\hline & Maximum & Average $^{a}$ & \\
\hline 1988 & 2.040 & 0.070 & 864 \\
\hline 1989 & 1.645 & 0.056 & 754 \\
\hline 1990 & 1.470 & 0.056 & 661 \\
\hline 1991 & 1.025 & 0.038 & 392 \\
\hline 1992 & 1.360 & 0.049 & 316 \\
\hline 1993 & 0.878 & 0.051 & 263 \\
\hline
\end{tabular}

$a_{\text {The average dose includes only workers who received a measurable dose }}$ during the year.

Table 2. SRS nonradioactive air emissions

\begin{tabular}{ll}
\hline Nonradioactive air emissions & $\begin{array}{c}\text { Maximum annual emissions rate } \\
\text { (tons/year) }\end{array}$ \\
\hline Mercury & $2.92 \times 10^{-1}$ \\
Nitric acid & $2.34 \times 10^{1}$ \\
Nitrous oxide & $4.55 \times 10^{1}$ \\
Oxides of nitrogen & $1.75 \times 10^{3}$ \\
Ammonia & $6.34 \times 10^{1}$ \\
N-Dodecane & $2.51 \times 10^{0}$ \\
Tributyl phosphate & $8.00 \times 10^{-2}$ \\
Volatile organic compounds & $2.64 \times 10^{0}$ \\
Ammonium nitrate & $1.18 \times 10^{-1}$ \\
Water & $5.92 \times 10^{0}$ \\
Tridecane & $3.26 \times 10^{-2}$ \\
\hline
\end{tabular}

\subsection{SPECIFIC FACILITIES INFORMATION NEEDS}

\subsubsection{Land Use}

Information on land use is given in Table 3.

Table 3. Land use

\begin{tabular}{llc}
\hline Proposed facility location & H-Canyon building (stack) & Building 773-A \\
\hline Latitude & $33.2888206 \mathrm{dec}$ deg & $33.344891 \mathrm{dec}$ deg \\
Longitude & $81.639562 \mathrm{dec}$ deg & $81.738549 \mathrm{dec}$ deg \\
Elevation 291-H Stack & $59.4 \mathrm{~m}(195 \mathrm{ft})$ above grade & \\
Proposed facility elevation & $94 \mathrm{~m}(308 \mathrm{ft})$ above sea level & \\
\hline
\end{tabular}




\subsubsection{Air Quality}

Analyses from the 1996 SCDHEC annual report on ambient air quality are shown in Table 4.

Table 4. Ambient air quality monitoring at three stations in the SRS area

\begin{tabular}{|c|c|c|c|c|c|c|}
\hline & \multicolumn{2}{|c|}{ Jackson } & \multicolumn{2}{|c|}{ Beech Island } & \multicolumn{2}{|c|}{ Barnwell } \\
\hline & Mean & $\begin{array}{l}\text { Maximum } \\
\qquad(1 \mathrm{~h})\end{array}$ & Mean & $\begin{array}{l}\text { Maximum } \\
\quad(1 \mathrm{~h})\end{array}$ & Mean & $\begin{array}{l}\text { Maximum } \\
(1 \mathrm{~h})\end{array}$ \\
\hline Carbon monoxide & $\mathrm{NR}^{a}$ & NR & NR & NR & NR & NR \\
\hline Nitrogen dioxide & $9 \mu \mathrm{g} / \mathrm{m}^{3}$ & 84 & NR & NR & 7 & 66 \\
\hline Sulfur dioxide & 4 & 132 & NR & NR & 3 & 52 \\
\hline Ozone & NR & 230 & NR & NR & NR & 194 \\
\hline $\begin{array}{l}\text { Particulate matter } \\
\left(\mathrm{PM}_{10}\right)\end{array}$ & 19 & 51 & NR & NR & 17 & 45 \\
\hline $\begin{array}{l}\text { Total suspended } \\
\text { particulates }\end{array}$ & NR & NR & 37 & 117 & NR & NR \\
\hline HAPs/TAPs ${ }^{b}$ & NR & NR & NR & NR & NR & NR \\
\hline
\end{tabular}

\subsubsection{Water}

Operation of the LA facilities at SRS will require use and discharge of process, cooling, and domestic water. All water used at SRS is from groundwater sources (Attachment D). An excerpt from the SRS Environmental Report for 1995 describes the hydrology and monitoring of the site's water supply (WSRCTR-96-0075). Discharge after treatment and monitoring is via site streams ultimately draining to the Savannah River. The SRS Environmental Report for 1995 also describes the characteristics and monitoring of site streams (Attachment E). The surface water section of the SRS Land-Use Baseline Report provides a map of site streams and wetlands (p.55). ${ }^{1}$

At this time, the flood plain maps have not been located. However, various authorization basis documents show that flooding, even with seismically induced catastrophic failures of the major dams upriver on the Savannah River, is not a credible accident for the facilities under consideration for the LA mission.

Additional information regarding water resources is available in Attachments D and E.

\subsubsection{Biological}

\subsubsection{Threatened and endangered species}

Several threatened, endangered, or candidate plants or animal species on federal, state, or U.S. Forest Service listings are known to occur on SRS. The U.S. Department of Energy has consulted with the U.S. Fish and Wildlife Service to determine the potential for endangered species to be affected, as required by the Endangered Species Act. However, SRS-developed areas contain no designated critical habitat for any listed threatened or endangered species. See the SRS Land-Use Baseline Report (pp. 42-43) for additional information and a map of threatened, endangered, and sensitive species habitat. None of these areas are within the area potentially affected by the LA program.

\subsubsection{Archaeology}

Archaeologically sensitive zones are shown on a map in the SRS Land-Use Baseline Report (p. 47). Because no new facilities are required for this program and all activity will occur within developed industrial areas, no impact is expected on archaeologically significant areas. 


\subsubsection{Infrastructure}

Information on infrastructure is given in Table 5.

Table 5. Facility 221-H infrastructure information

\begin{tabular}{|c|c|c|c|c|}
\hline \multirow[b]{2}{*}{ Utilities and wastewater } & \multicolumn{2}{|c|}{ Current usage } & \multicolumn{2}{|c|}{ Current capacity } \\
\hline & Average & Peak & Average & Peak \\
\hline Water, L/year (gal/year) & $3.8 \times 10^{8}\left(10^{3}\right)$ & $3.8 \times 10^{8}\left(10^{8}\right)$ & $\begin{array}{l}15 \times 10^{9} \\
\left(4 \times 10^{9}\right)\end{array}$ & $\begin{array}{l}15 \times 10^{9} \\
\left(4 \times 10^{9}\right)\end{array}$ \\
\hline $\begin{array}{l}\text { Sanitary wastewater, L/year } \\
\text { (gal/year) }\end{array}$ & $\begin{array}{l}19 \times 10^{6} \\
\left(5 \times 10^{6}\right)\end{array}$ & $\begin{array}{l}19 \times 10^{6} \\
\left(5 \times 10^{6}\right)\end{array}$ & $\left(36 \times 10^{6}\right)$ & $\left(36 \times 10^{6}\right)$ \\
\hline $\begin{array}{l}\text { Process wastewater, L/year } \\
\text { (gal/year) }\end{array}$ & $\left(36 \times 10^{6}\right)$ & $\left(36 \times 10^{6}\right)$ & $\begin{array}{l}5.7 \times 10^{8} \\
\left(1.5 \times 10^{8}\right)\end{array}$ & $\begin{array}{l}5.7 \times 10^{8} \\
\left(1.5 \times 10^{8}\right)\end{array}$ \\
\hline Electricity, MW/year (MWh/year) & $\left(12 \times 10^{4}\right)$ & $\left(12 \times 10^{4}\right)$ & $\left(50 \times 10^{4}\right)$ & $\left(50 \times 10^{4}\right)$ \\
\hline Natural gas, $\mathrm{m}^{5} /$ year (scf/year) & None & None & None & None \\
\hline Fuel oil, L/year (gal/year) & NA & NA & NA & NA \\
\hline Steam, $\mathrm{kg} / \mathrm{h}(\mathrm{lb} / \mathrm{h})$ & $\begin{array}{l}5 \times 10^{4} \\
\left(1.2 \times 10^{5}\right)\end{array}$ & $\begin{array}{l}1.3 \times 10^{3} \\
\left(3 \times 10^{5}\right)\end{array}$ & $\begin{array}{l}6 \times 10^{5} \\
\left(1.3 \times 10^{6}\right)\end{array}$ & $\begin{array}{l}6 \times 10^{5} \\
\left(1.3 \times 10^{6}\right)\end{array}$ \\
\hline
\end{tabular}

\subsubsection{Waste Management}

Information on waste management is given in Table 6.

Table 6. Waste management information

\begin{tabular}{|c|c|c|c|c|c|c|}
\hline \multirow[b]{2}{*}{ Waste category } & \multirow[b]{2}{*}{$\begin{array}{l}\text { Current annual } \\
\text { generation rate }\end{array}$} & \multirow[b]{2}{*}{$\begin{array}{l}\text { Amount in } \\
\text { inventory }\end{array}$} & \multicolumn{4}{|c|}{ Available TSD facilities $^{a}$} \\
\hline & & & $\begin{array}{c}\text { Building name } \\
\text { or number }\end{array}$ & $\begin{array}{l}\text { TSD } \\
\text { method }\end{array}$ & Inventory & Capacity \\
\hline \multicolumn{7}{|l|}{ Transuranic (TRU) } \\
\hline Liquid, L (gal) & 2,378 & 126,264 & DWPF $^{a}$ & Vit glass & & \\
\hline Solid, $\mathrm{m}^{3}\left(\mathrm{ft}^{3}\right)$ & 147.8 & 3,359 & Z-Area & Storage & & \\
\hline \multicolumn{7}{|l|}{ Mixed TRU } \\
\hline \multicolumn{7}{|l|}{ Liquid, L (gal) } \\
\hline Solid, $\mathrm{m}^{3}\left(\mathrm{ft}^{3}\right)$ & 16.85 & 7,207 & Z-Area & Storage & & \\
\hline \multicolumn{7}{|c|}{ Low-level waste (LLW) } \\
\hline Liquid, L (gal) & $53,000^{a}$ & $\mathrm{~N} / \mathrm{A}^{a}$ & Z-Area & Saltstone & & \\
\hline Solid, $\mathrm{m}^{3}\left(\mathrm{ft}^{3}\right)$ & $6,598.5$ & 680,000 & CIF & Incinerate & & \\
\hline Mixed LLW & & 3,143 & & & & \\
\hline Liquid, L (gal) & 444.21 & & SRTC & Storage & & \\
\hline Solid, $\mathrm{m}^{3}\left(\mathrm{ft}^{3}\right)$ & 22.69 & & Z-Area & Storage & & \\
\hline \multicolumn{7}{|l|}{ Hazardous } \\
\hline \multicolumn{7}{|l|}{ Liquid, L (gal) } \\
\hline Solid, $\mathrm{m}^{3}\left(\mathrm{ft}^{3}\right)$ & 62.15 & 1,619 & Z-Area & Storage & & \\
\hline \multicolumn{7}{|l|}{$\begin{array}{l}\text { Nonhazardous } \\
\text { (sanitary-industrial) }\end{array}$} \\
\hline Solid, $\mathrm{m}^{3}\left(\mathrm{ft}^{3}\right)$ & 6,075 & N/A & Off-site & Disposal & & \\
\hline \multicolumn{7}{|l|}{ Nonhazardous (other) } \\
\hline Liquid, L (gal) & & & & & & \\
\hline Solid, $\mathrm{m}^{3}\left(\mathrm{ft}^{3}\right)$ & & & & & & \\
\hline
\end{tabular}

${ }^{a}$ Defense waste processing facility (DWPF) recycle by-produist not normally included in generation data. 


\section{REFERENCE}

1. J. C. Noah et al., Land-Use Baseline Report: Savannah River Site, WSRC-TR-95-0276, Westinghouse Savannah River Co., June 1995. 
Page Intentionally Blank 


\section{ATTACHMENT A}

RADIOACTIVE EMISSIONS

FROM 221-H FACILITY 


\section{YTD 1997Values mas $8 / 7 / 97$}

Release Mode:

Source or Discharge Point: 291-H Stack Isokinetic

Radionuclide

$I-131$

Cs -134

Cs -137

$\mathrm{Pu}-238$

$\mathrm{Pu}-239$

Am-241

$\mathrm{Cm}-244$

Sr $-89,90$

Gross B

Gross A
Quantity

Released (Ci)

$$
\begin{aligned}
& 2.83 E-06 \\
& 0.00 E+00 \\
& 0.00 E+00 \\
& 1.42 E-06 \\
& 4.47 E-07 \\
& 1.49 E-08 \\
& 2.14 E-07 \\
& 0.00 E+00 \\
& 0.00 E+00 \\
& 0.00 E+00
\end{aligned}
$$

Year-to-date Released ( $\mathrm{Ci}$ )

$4.84 \mathrm{E}-06$

$9.11 \mathrm{E}-07$

$5.05 E-05$

1. $49 \mathrm{E}-05$

$5.83 \mathrm{E}-06$

$7.65 E-07$

2. 29E-05

1. $71 \mathrm{E}-05$

4. $24 \mathrm{E}-05$

2. $33 E-05$
Year-to-date EDE (mrem)
$5.81 E-08$
1. $00 \mathrm{E}-07$
9. $60 \mathrm{E}-06$
$6.24 \mathrm{E}-05$
2. $74 \mathrm{E}-05$
$3.75 \mathrm{E}-06$
$5.72 \mathrm{E}-05$
1. $44 \mathrm{E}-06$
$0.00 E+00$
$0.00 E+00$

Year-to-date Total: $1.62 \mathrm{E}-04$ 
Preliminary 1996 Values

Release Mode: Source or Discharge Point: 291-H Stack Isokinetic

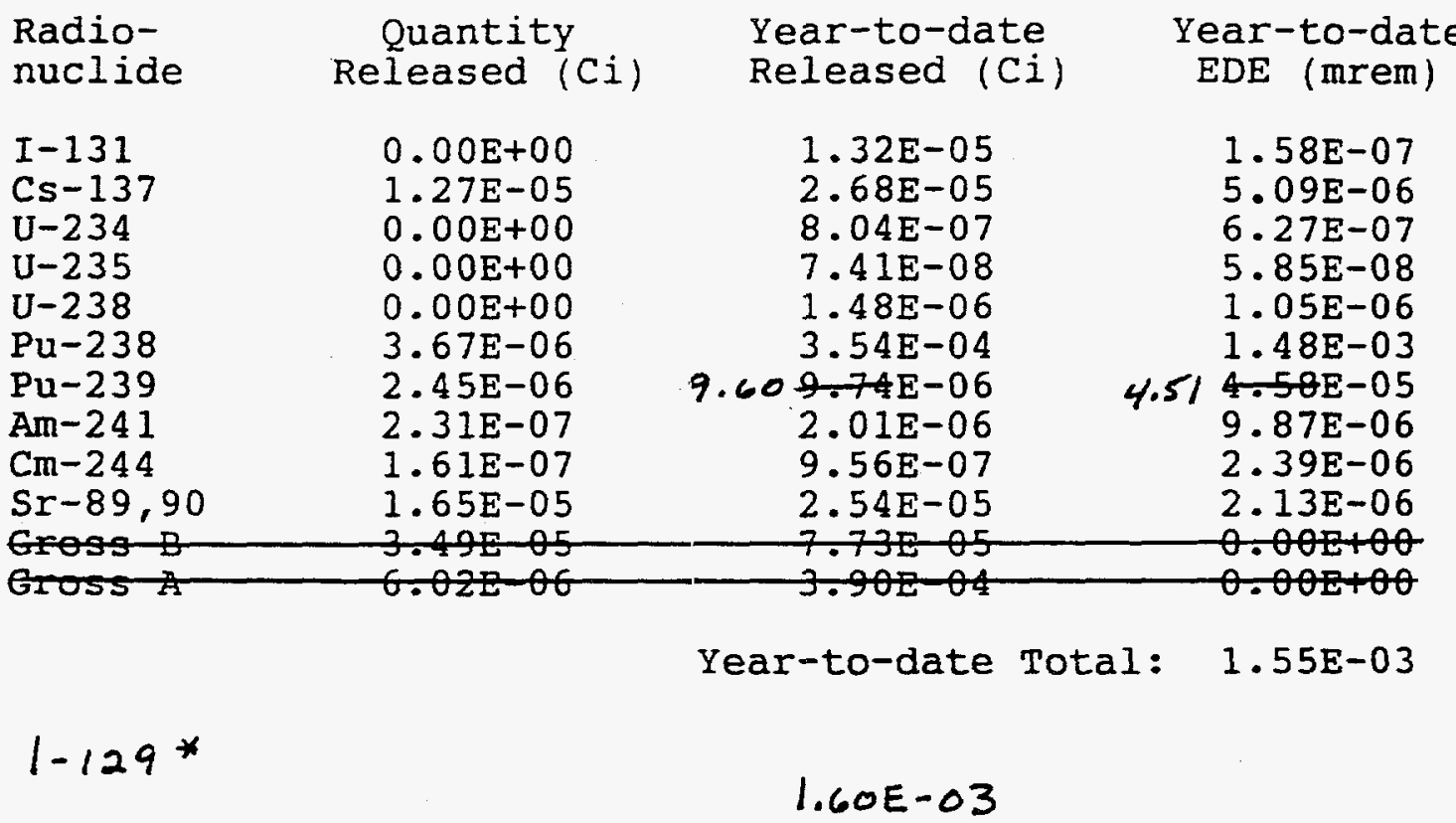

* Obtained fram SRTC (AIBoni's Groug ) repocted ix " $\mu$ Ci." 
Table 9

Radioactive Atmospheric Releases by Stack/Facility and Comparison of Annual Average Concentrations to DOE Derived Concentration Guides

Page 4 of 6

\begin{tabular}{|c|c|c|c|c|c|}
\hline Stack/Facility & Radionuclide & $\begin{array}{c}\text { Quantity } \\
\text { Released During } \\
1995(\mu \mathrm{Ci})\end{array}$ & $\begin{array}{l}\text { Atmospheric } \\
\text { Release } \\
\text { Volume (mL) }\end{array}$ & $\begin{array}{l}\text { Average Effluent } \\
\text { Concentration } \\
\text { During } 1995 \\
(\mu \mathrm{Ci} / \mathrm{mL})\end{array}$ & $\begin{array}{c}\text { DOE DCGs } \\
(\mu \mathrm{Ci} / \mathrm{mL})\end{array}$ \\
\hline \multicolumn{6}{|l|}{ F Main (195') } \\
\hline \multicolumn{6}{|c|}{ H-Area (Separations and Waste Management) } \\
\hline \multicolumn{6}{|c|}{ 230-H Lag } \\
\hline \multicolumn{6}{|l|}{ 230-H Process } \\
\hline $\begin{array}{l}241-84 H \text { (ETF } \\
\text { Lab) }\end{array}$ & Cs-137 & $9.88 E-02$ & $4.51 E+13$ & $2.19 E-15$ & $4.0 E-10$ \\
\hline \multicolumn{6}{|l|}{$\begin{array}{l}\text { 241-84H (ETF } \\
\text { Process) }\end{array}$} \\
\hline 241-H Misc & Cs-137 & $8.11 E+00$ & $5.52 E+15$ & $1.47 E-15$ & 4.0E-10 \\
\hline \multirow[t]{2}{*}{ 241-H Purge } & Cs-134 & $1.90 E-01$ & $1.46 \mathrm{E}+15$ & $1.30 \mathrm{E}-16$ & $2.0 E-10$ \\
\hline & Cs-137 & $1.06 E+02$ & $1.46 \mathrm{E}+15$ & $7.26 \mathrm{E}-14$ & $4.0 E-10$ \\
\hline 241-H Annulus & Cs-137 & $1.34 E+02$ & $5.94 E+15$ & $2.26 \mathrm{E}-14$ & $4.0 E-10$ \\
\hline 244-H RBOF & Cs137 & $2.42 E+01$ & $3.60 E+14$ & $6.72 E-14$ & $4.0 E-10$ \\
\hline $\begin{array}{l}\text { 244-HRBOF } \\
\text { Vessel Vent }\end{array}$ & Cs137 & $5.62 E-01$ & $3.70 E+12$ & $1.52 E-13$ & 4.0E-10 \\
\hline \multicolumn{6}{|l|}{$\begin{array}{l}\text { 253-H Waste } \\
\text { Compactor }\end{array}$} \\
\hline \multirow[t]{3}{*}{ 291-H Isokinetic } & $\mathrm{Sr}-89,90$ & $1.20 E+01$ & $4.05 E+15$ & $2.96 E-15$ & $9.0 \mathrm{E}-12$ \\
\hline & $1-129$ & $1.70 E+03$ & $4.05 E+15$ & $4.20 E-13$ & $7.0 \mathrm{E}-12$ \\
\hline & $1-131$ & $7.98 E+00$ & $4.05 E+15$ & $1.95 E-15$ & $4.0 E-10$ \\
\hline & Cs-137 & $2.50 E+01$ & $4.05 E+15$ & $6.17 E-15$ & $4.0 E-10$ \\
\hline & $U-234$ & $2.26 E-01$ & $4.05 E+15$ & $5.58 \mathrm{E}-17$ & $9.02 E-14$ \\
\hline & $u-235$ & $1.43 \mathrm{E}+01$ & $4.05 E+15$ & $3.53 E-15$ & $1.0 E-13$ \\
\hline & $U-238$ & $-1.00 \mathrm{E}+00$ & $4.05 E+15$ & 2.47E-16 & $1.0 E-13$ \\
\hline & Pu-238 & $4.66 \mathrm{E}+02$ & $4.05 E+15$ & $1.15 \mathrm{E}-13$ & $3.0 E-14$ \\
\hline & Pu-239 & $8.70 E+\infty 0$ & $4.05 E+15$ & $2.15 E-15$ & $2.0 E-14$ \\
\hline & Am-241 & $6.26 \mathrm{E}-01$ & $4.05 E+15$ & $1.55 \mathrm{E}-16$ & $2.0 E-14$ \\
\hline & $\mathrm{Cm}-244$ & $8.21 E-01$ & $4.05 E+15$ & $2.03 E-16$ & $4.0 E-14$ \\
\hline
\end{tabular}

a Source: DOE Order 5400.5. In cases where different chemical forms have different DCGs, the lowest DCG for the radionuclide is given. These DCGs are defined as the air concentration of that radionuclide that will give a 50-year committed effective dose equivalent of 100 mrem under conditions of continuous exposure for one year. DCGs are reference values only and are not considered release limits or standards. 
Table 6

1994 Radioactive Atmospheric Releases by Stack/Facility and Comparison of Annual Average Concentrations to DOE Derived Concentration Guides

Page 4 of 5

\begin{tabular}{|c|c|c|c|c|c|}
\hline Stack/Facility & Radionuclide & $\begin{array}{c}\text { Quantity } \\
\text { Released During } \\
1994(\mu \mathrm{Cl})\end{array}$ & $\begin{array}{l}\text { Atmospheric } \\
\text { Release } \\
\text { Volume }(\mathrm{mL})\end{array}$ & $\begin{array}{c}\text { Average Effluent } \\
\text { Concentration } \\
\text { During } 1994 \\
(\mu \mathrm{Ci} / \mathrm{mL})\end{array}$ & $\begin{array}{c}\text { DOE DCGsa } \\
(\mu \mathrm{Ci} / \mathrm{mL})\end{array}$ \\
\hline 241-H Annulus & Cs-137 & $5.09 E+00$ & $7.94 E+14$ & $6.41 E-15$ & $4.0 E-10$ \\
\hline 244-H RBOFb & Cs-137 & $2.82 E-01$ & $3.56 E+14$ & $7.92 E-16$ & $4.0 E-10$ \\
\hline $\begin{array}{l}\text { 244 H RBOF } \\
\text { Vessel Vent }\end{array}$ & Cs-137 & 2.37E-02 & $5.73 E+12$ & $4.14 E-15$ & $4.0 E-10$ \\
\hline $\begin{array}{l}\text { 253-H Waste } \\
\text { Compactor }\end{array}$ & H-3 (oxide) & $4.43 E+00$ & $6.03 E+13$ & $7.35 E-14$ & $1.0 E-07$ \\
\hline \multirow[t]{8}{*}{ 291-H Isokinetic } & $S_{r}-89,90$ & $1.16 E+01$ & $3.89 E+15$ & $2.98 E-15$ & $9.0 E-12$ \\
\hline & $|-13|$ & $2.19 E+01$ & $3.89 E+15$ & $5.63 E-15$ & 4.0E-10 \\
\hline & Cs-137 & $3.03 E+00$ & $3.89 E+15$ & $7.79 E-16$ & $4.0 E-10$ \\
\hline & $U-235,238$ & $7.68 E+01$ & $3.89 E+15$ & $1.97 E-14$ & $1.0 E-13$ \\
\hline & Pu-238 & $1.46 E+03$ & $3.89 E+15$ & $3.75 E-13$ & $3.0 E-14$ \\
\hline & Pu-239 & $5.92 E+01$ & $3.89 E+15$ & $1.52 E-14$ & $2.0 E-14$ \\
\hline & Am-241,243 & $5.21 E+00$ & $3.89 E+15$ & $1.34 E-15$ & $2.0 E-14$ \\
\hline & $\mathrm{Cm}-242,244$ & $1.64 E+00$ & $3.89 E+15$ & $4.22 E-16$ & 4.0E-14 \\
\hline $299-H$ & Cs-137 & $4.26 E-01$ & $2.95 E+14$ & $1.44 \mathrm{E}-15$ & $4.0 E-10$ \\
\hline \multirow[t]{3}{*}{ H Main(195') } & $U-235,238$ & $9.00 E+01$ & $2.00 E+15$ & $4.50 E-14$ & $1.0 E-13$ \\
\hline & $P u-238$ & $8.47 E+00$ & $2.00 E+15$ & $4.24 E-15$ & $3.0 E-14$ \\
\hline & Pu-239 & $1.45 E+00$ & $2.00 E+15$ & $7.25 E-16$ & $2.0 E-14$ \\
\hline \multirow[t]{2}{*}{ Tritium } & H-3 (oxide) & 8.31E+10 & $1.36 E+15$ & $6.11 \mathrm{E}-05$ & $1.0 E-07$ \\
\hline & $\mathrm{H}-3$ (element) & $5.29 E+10$ & $1.36 E+15$ & $3.89 E-05$ & $2.0 E-02$ \\
\hline \multicolumn{6}{|c|}{ 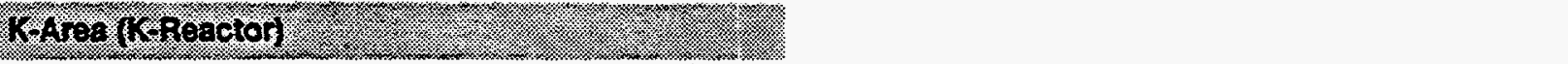 } \\
\hline K Main (148') & H-3 (oxide) & $1.11 E+10$ & $2.31 E+15$ & $4.81 E-06$ & $1.0 E-07$ \\
\hline \multirow[t]{2}{*}{ K Disassembly } & H-3 (oxide) & $1.49 E+09$ & $1.74 E+15$ & $8.56 E-07$ & $1.0 E-07$ \\
\hline & Cs-137 & $9.44 E-01$ & $1.74 E+15$ & $5.43 E-16$ & $4.0 E-10$ \\
\hline \multicolumn{3}{|l|}{ (1) } & & . & \\
\hline L Main (148') & H-3 (oxide) & 2.17E+09 & $2.65 E+15$ & $8.19 E-07$ & $1.0 E-07$ \\
\hline
\end{tabular}

a Source: DOE Order 5400.5. In cases where different chernical forms have different DCGs, the lowest DCG for the radionuclide is given. These DCGs are defined as the air concentration of that radionuclide that will give a 50-year committed dose of $100 \mathrm{mrem}$ under conditions of continuous exposure for one year. DCGs are reference values only and are not considered release limits or standards.

b Receiving Basin for Ottsite Fuel 


\section{ATTACHMENT B}

\section{RADIOLOGICAL \\ AIR-SURVEILLANCE STATIONS}


RADIOLOGICAL AIR-SURVEILLANCE STATIONS

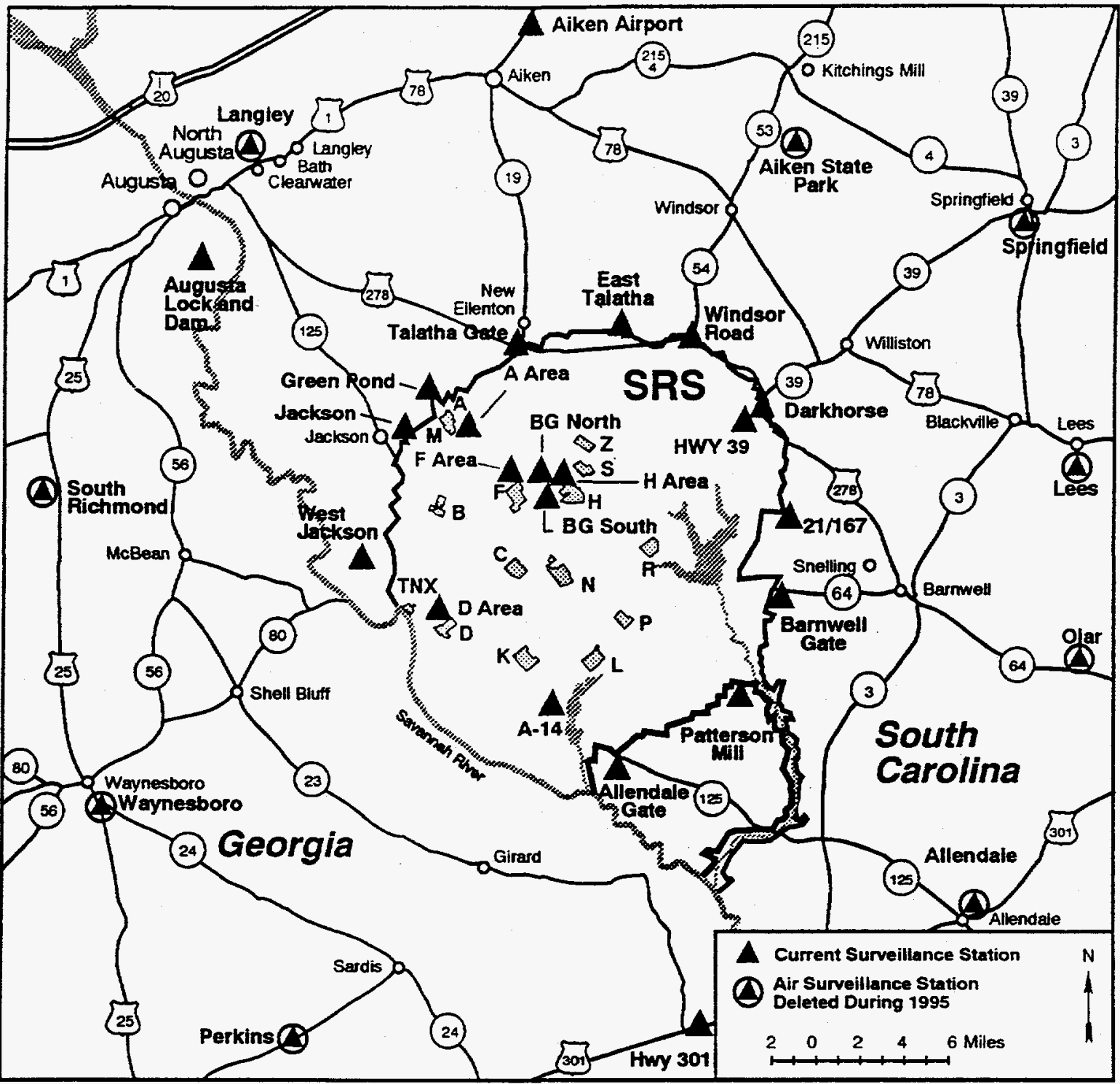

$96 \times 01678.02$

Figure 6-1 Radiological Air-Surveillance Stations

The SRS air surveillance program consists of 31 stations located within 25 miles of the site and four stations (not shown) approximately 100 miles from the site.

\section{Gross Alpha and Gross Beta}

Gross alpha and gross beta activity analyses are performed on glass fiber filter papers. Although they cannot provide concentrations of specific radionuclides, these measurements are useful in providing information for trending of the total activity in an air sample or in screening samples.

The results from 1995 are presented in table 6-2. Both the average gross alpha and average gross beta results are consistent with 1994 measured concentrations and also agree with historical results.
As observed in previous years, no significant difference was observed between the average concentrations measured on site near the operating facilities and the average concentrations observed at the site perimeter and beyond. Although a spike was observed in the 1991 gross alpha concentration, the historical data set indicates a relatively stable ambient level of gross activity in the air.

\section{Gamma-Emitting Radionuclides}

Glass fiber filters and activated charcoal canisters are collected weekly and analyzed for gamma-emitting radionuclides. The only manmade gamma emitting 
ATTACHMENT C

WIND ROSE FOR SRS, 1987-1991 

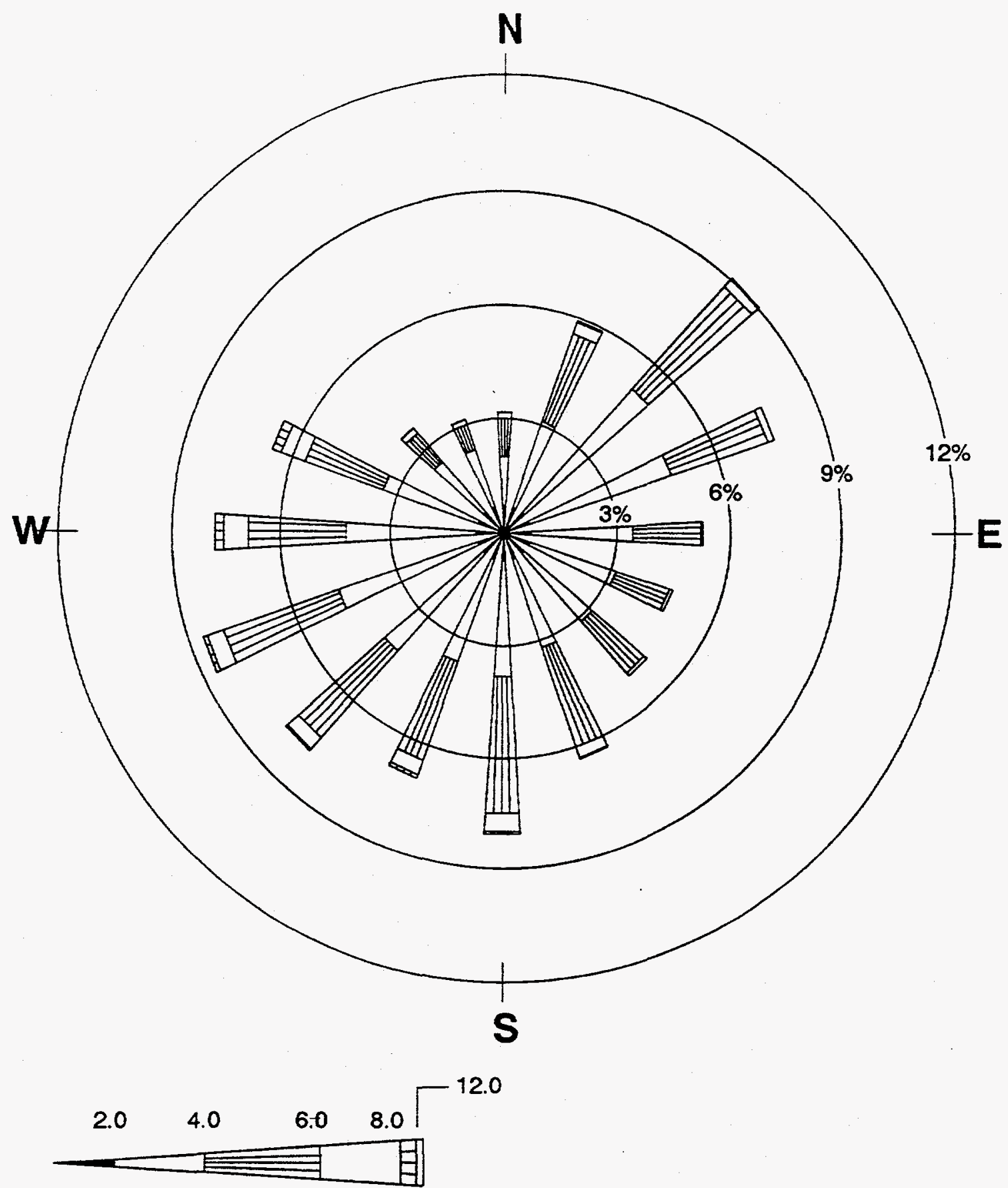

Wind Speed Class Boundaries

(MetersiSecond)

Figure 7-1 Wind Rose for SRS, 1987-1991

The wind rose plot shows the percent of occurrence frequencies of wind direction and speed at SRS. The plot is based on a composite of hourly averaged wind data from the SRS meteorological tower network for the fiveyear period 1987-1991. Measurements were taken 200 feet above the ground. Directions indicated are from which the wind blows. 
ATTACHMENT D

GROUNDWATER 


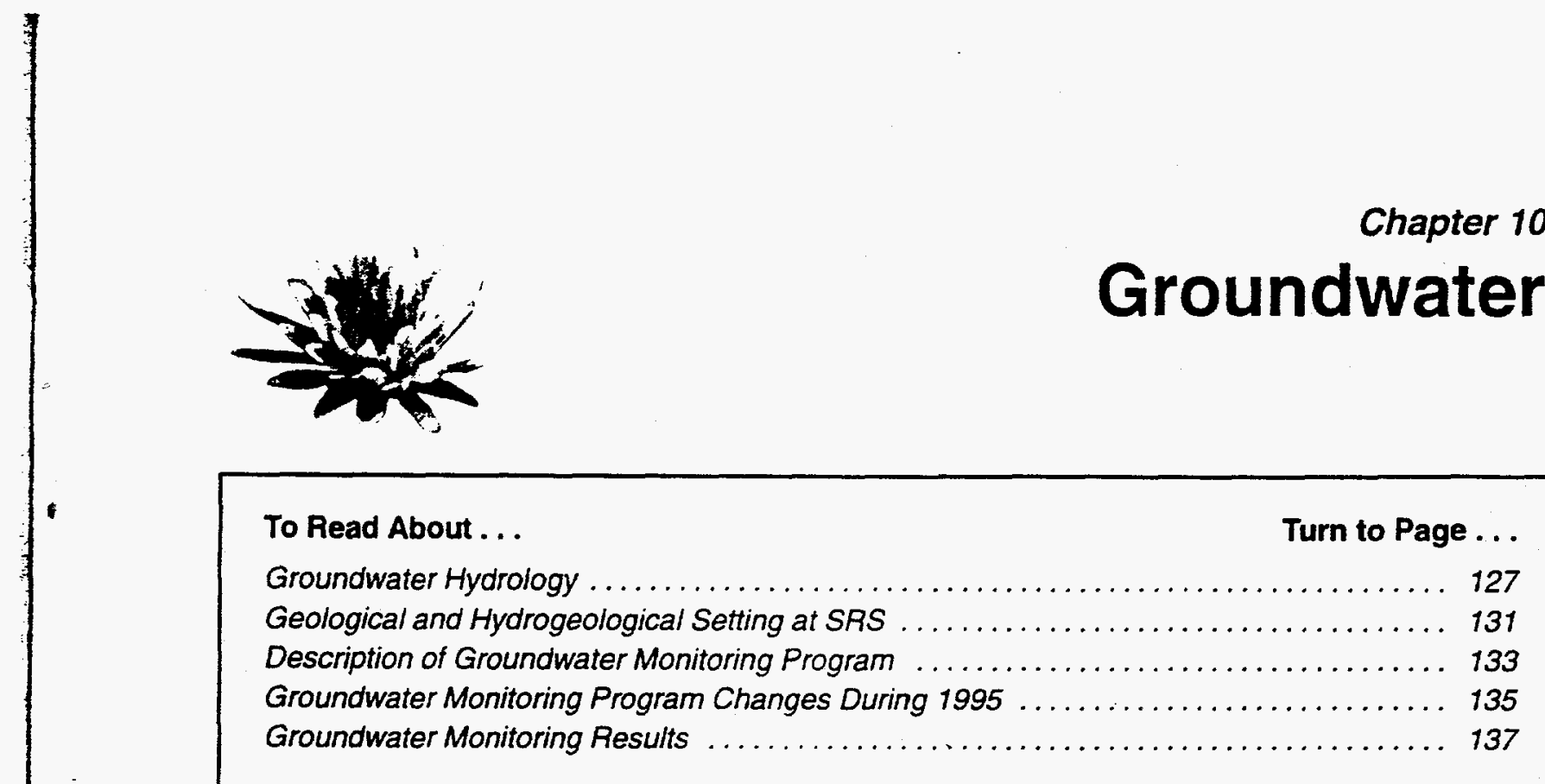

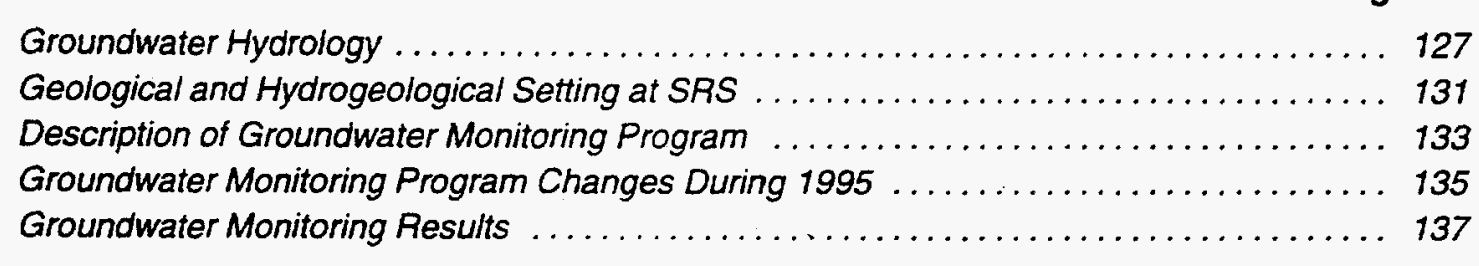

$\mathrm{G}$ ROUNDWATER beneath an estimated 5 to 10 percent of the Savannah River Site (SRS) has been contaminated by industrial solvents, tritium, metals, or other constituents used or generated by operations at SRS. There is no evidence that groundwater contaminated with these constituents has migrated off site. Groundwater in areas indicated on figure 10-1 (page 128) contains one or more of these constituents at or above the levels of Safe Drinking Water Act primary drinking water standards (DWS) of the U.S. Environmental Protection Agency (EPA).

This chapter describes the groundwater monitoring results for approximately 1,600 wells in 94 locations (figure 10-1) within designated areas at SRS. Only summaries of the results exceeding the standards discussed on page 136 will be found in this report. Detailed results may be found in the following public documents: The Savannah River Site's Groundwater Monitoring Program. First Quarter 1995 (ESH-EMS-950393); The Savannah River Site's Groundwater Monitoring Program, Second Quarter 1995 (ESH-EMS-950394); The Savannah River Site's Groundwater Monitoring Program, Third Quarter 1995 (ESH-EMS-950395); The Savannah River Site's Groundwater Monitoring Program, Fourth Quarter 1995 (ESH-EMS-950396). Full results for each well sampled during a quarter are presented alphabetically in the quarterly reports.

Another public document, the Environmental Protection Department's Well Inventory (ESH-EMS-950419), contains detailed maps of the wells at each monitored location.

During 1995, most analytical results were similar to those of recent years. Wells at the F-Area tank farm were resampled for trichlorofluoromethane (Freon 11) because elevated levels were reported in 1994. when the wells were first sampled for specific volatile organic compounds. Elevated levels again were reported in two wells.

Strontium-89, with a half-life of 50 days, again was reported at elevated levels in F-Area and H-Area seepage basins and in F-Area canyon wells. Based on the last operations date for processes that produce strontium-89, Westinghouse Savannah River Company (WSRC) considers positive results for strontium-89 to originate from errors in the laboratory.

\section{Groundwater Hydrology}

Groundwater aquifers are pathways by which potentially hazardous substances at SRS may enter nearby streams and eventually the Savannah River. Substances in the soil may dissolve in rainwater, which moves them downward through the unsaturated zone to the water tabie. The water then flows downgradient toward a discharge point.

To identify the extent of contamination in groundwater and to predict the possible fate of the contaminants, scientists must determine the location and movement of groundwater. To make this determination, an understanding is required about how groundwater moves, in general, and how that movement will be influenced by the specific geologic setting at SRS.

When rain falls, part of the rainwater soaks into the ground, infiltrating soil and rock. The accumulation of groundwater in pore spaces of sediments creates sources of useable water. Groundwater eventually reappears at the surface in springs, swamps, streambeds, riverbeds, or wells. Thus, groundwater is a reservoir whose primary input is rainwater 


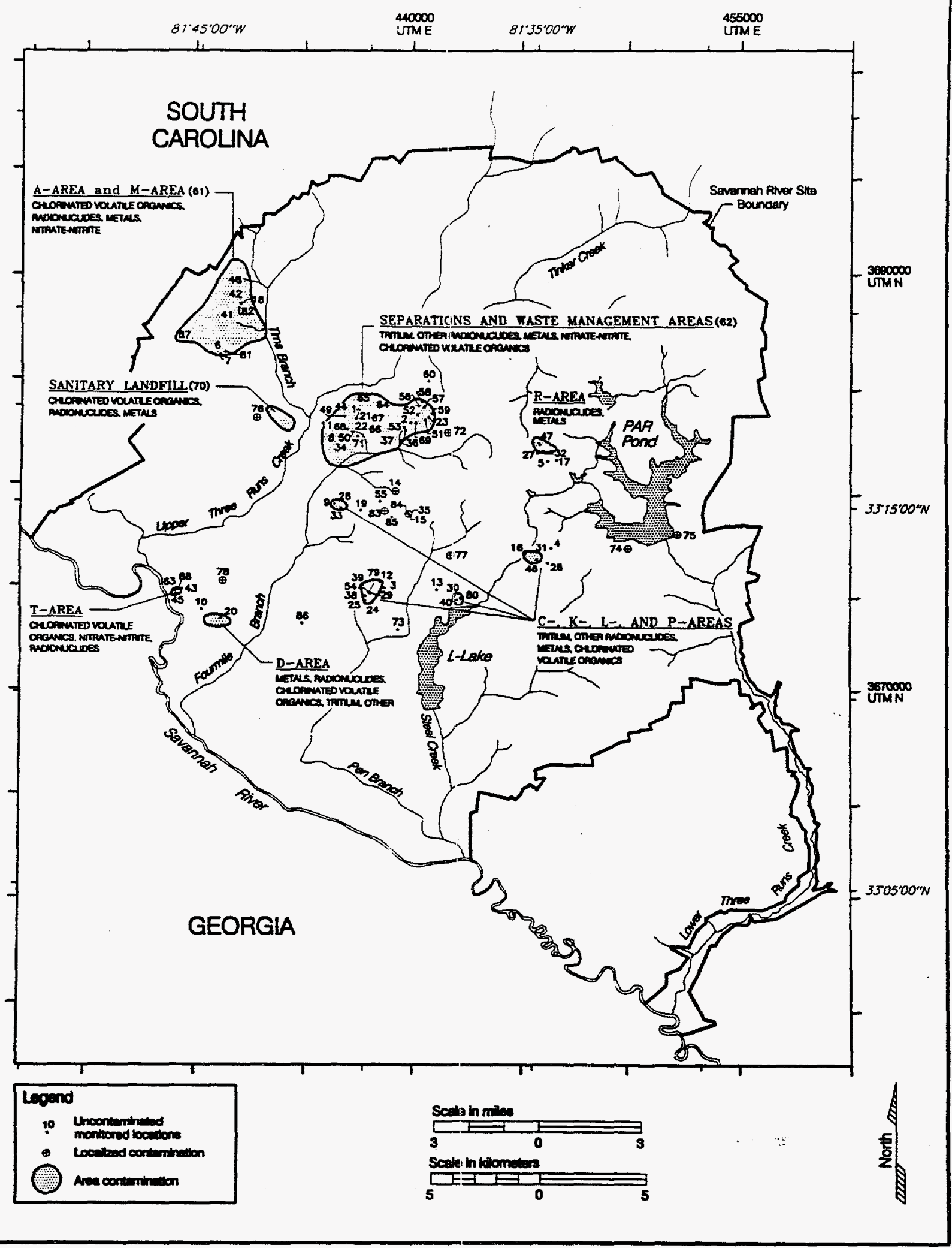

Exploration Resources, Inc.

Figure 10-1 Facilities Monitored by the SAS Monitoring Well Network, Including Areas Having Constituents Exceeding Drinking Water Standards in 1995 
Key for Figure 10-1

\section{Acid/Caustic Basins}

$$
\begin{aligned}
& \text { 1. F-Area Acid/Caustic Basin } \\
& \text { 2. H-Area Acid/Caustic Basin } \\
& \text { 3. K-Area Acid/Caustic Basin } \\
& \text { 4. P-Area Acid/Caustic Basin } \\
& \text { 5. R-Area Acid/Caustic Basin }
\end{aligned}
$$

Burning/Rubble, Rubble, and Metals Burning Pits

6. A-Area Burning/Rubble Pits and A-Area Ash Pile

7. A-Area Metals Buming Pit

8. Burma Road Rubble Pit

9. C-Area Buming/Rubble Pit

10. D-Area BumingiRubble Pits

11. F-Area Burning/Rubble Pits

12. K-Area Burning/Rubble Pit

13. L-Area Burning/Rubble Pit

14. N-Area (formenty Central Shops) Burning/Rubble Pits

15. N-Area Buming/Rubble Pit South

16. P-Area Burning/Rubble Pit

17. R-Area Buming/Rubble Pits

Coal Pile Runoff Containment Basins, Ash Basins, and Coal Piles

18. A-Area Coal Pile Runoff Containment Basin

19. C-Area Coal Pile Runoft Containment Basin

20. D-Area Coal Pile Runoff Containment Basin and Ash Basins

21. F-Area Ash Basin

22. F-Area Coal Pile Runoff Containment Basin

23. H-Area Coal Pile Runoff Containment Basin

24. K-Area Ash Basin

25. K-Area Coal Pile Runoff Containment Basin

26. P-Area Coal Pite Runoff Containment Basin

27. R-Area Coal Pile

\section{Disassembly Basins}

28. C-Area Disassembly Basin

29. K-Area Disassembly Basin

30. L-Area Disassembly Basin

31. P-Area Disassembly Basin

32. R-Area Disassembly Basin

\section{Seepage and Retention Basins}

33. C-Area Reactor Seepage Basins

34. F-Area Seepage Basins and Inactive Process Sewer Line

35. Ford Building Seepage Basin

36. H-Area Retention Basins

37. H-Area Seepage Basins and inactive Process Sewer Line

38. K-Area Reactor Seepage Basin

39. K-Area Retention Basin

40. L-Area Reactor Seepage Basin

41. M-Area Hazardous Waste Management Facility

42. Metallurgical Laboratory Seepage Basin

43. New TNX Seepage Basin

44. Old F-Area Seepage Basin

45. Old TNX Seepage Basin

46. P-Area Reactor Seepage Basins

47. R-Area Reactor Seepage Basins

48. Savannah River Laboratory Seepage Basins

\section{Operating Buildings and Facilities}

49. F-Area Canyon Building and A-Line Uranium Recovery Facility

50. F-Area Effluent Treatment Cooling Water Basin

51. H-Area Auxiliary Pump Pit

52. H-Area Canyon Building

53. H-Area Effluent Treatment Cooling Water Basin

54. K-Area Tritium Sump

55. N-Area Hazardous Waste Storage Facility

56. S-Area Facilities

57. S-Area Low-Point Pump Pit

58. S-Area Vitrification Building

59. Z-Area Low-Point Drain Tank

60. Z-Area Saltstone Manufacturing and Disposal Facility

Plume Monitoring

61. A-Area and M-Area

62. Separations and Waste Management Areas

63. T-Area (TNX)

Radioactive Waste Storage and Disposal Facilities

64. Burial Ground Expansion (E-Area Vautts)

65. Hazardous Waste/Mixed Waste Disposal Facility

66. Old Burial Ground

67. Radioactive Waste Burial Ground

68. F-Area Tank Farm

69. H-Area Tank Farm

\section{Sanitary Landfill}

70. Sanitary Landfill and Interim Sanitary Landfill

\section{Sludge Application Sites}

71. F-Area Sanitary Sludge Land Application Site

72. H-Area Sanitary Sludge Land Application Site

73. K-Area Sludge Land Application Site

74. PAR Pond Sludge Land Application Site

75. Second PAR Pond Borrow Pit Sewage Sludge Application Site

\section{Other Sites}

76. B-Area Gas Station

77. Chemicals, Metals, and Pesticides Pits

78. D-Area Oil Disposal Basin

79. K-Area Diesel Tank Spill

80. L-Area Acid/Caustic Basin and L-Area Oil \& Chemical Basin

81. Miscellaneous Chemical Basin

82. Motor Shop Oil Basin

83. N-Area Diesel Spill

84. N-Area Fire Department Training Facility

85. N-Area Hydrofluoric Acid Spill

86. Road A (Baxley Road) Chemical Basin

87. Silverton Road Waste Site

88. TNX Burying Ground 
infiltrating the soil and whose output is discharge to springs, swamps, streams, rivers, and wells.

Water from the surface moves into the soil by percolating downward through the pore spaces between sediment grains; smaller pore spaces mean that less water flows through the sediment. The physical property that describes the ease with which water may move through the pore spaces and cracks in a solid is called permeability, which is deternined largely by the number and size of pore spaces in the solid and by how the pore spaces are connected.

As water infiltrates the earth, it travels down through the unsaturated zone, where the pore spaces are filled partly with water and partly with air. Water moving through the unsaturated zone eventually reaches the top of the saturated zone (water table), where the pore spaces are completely filled with water. The water table generally follows, in subtle form, the contour of the surface topography. Springs, swamps, and beds of streams and rivers are the outcrops of the water table, where groundwater is discharged to the surface.

Groundwater beneath SRS flows slowly-at rates ranging from inches to several hundred feet per year-toward streams and swamps on site and into the Savannah River. Figures 10-2 (page 162) ard 10-3 (page 163) illustrate the potentiometric contours and horizontal-flow directions of two regional aquifers monitored beneath SRS. Similar to contour lines on a weather map that connect points of equal barometric pressure, the figures' potentiometric surface contour lines connect below-ground regions of equal hydraulic head (elevation of the water in a well or piezometer).

Horizontal-flow directions of groundwater within these aquifers are indicated on figures $10-2$ (page 162 ) and 10-3 (page 163) by bold arrows perpendicular to the contour lines. In both aquifers, the direction of flow beneath monitored waste sites generally is toward the Savannah River, the Savannah River Swamp, Upper Three Runs Creek, or Lower Three Runs Creek. Surface water in the swamp and creeks eventually flows into the Savannah River.

The flow of groundwater and the position of the water table may be complicated by variations in the permeability of the subsurface. Because the earth's permeability varies greatly, groundwater does not travel at a constant rate or without impediment. Strata that transmit water easily (such as those composed primarily of sand) are called aquifers, and strata that restrict water movement (such as clay layers) are called aquitards. A fully saturated aquifer with an aquitard lying above it is termed a confined aquifer.
Groundwater moves through aquifers toward natural exits, or discharge points, to reappear at the surface.

The direction of groundwater flow through an aquifer system is determined only partly by the permeability of the strata containing the aquifer. The hydraulic head is a function of the energy associated with elevation and the pressures exerted by surrounding water. Hydraulic gradient-the difference in hydraulic head over a specified distance-is the driving force for groundwater movement. Because hydraulic head is not just a function of elevation, downgradient is not necessarily synonymous with downhill. The downgradient direction will have a horizontal and vertical component, just as a household drain moves wastewater both horizontally and vertically toward the lowest point of exit. Aquitards deflect groundwater movement just as drainpipe walls control the direction of wastewater movement. In an aquifer constrained by aquitards such as horizontal clay layers, the downgradient direction tends to be more horizontal than vertical.

Monitoring wells are used extensively at SRS to assess the effect of operations on groundwater quality-generally to determine the effect of a specific site on groundwater quality nearby. Wells positioned to intercept the groundwater flowing away from a site are called downgradient wells, while wells placed to intercept groundwater before it flows under a site are called upgradient wells. Wells sampling groundwater flowing next to a site are called sidegradient wells. Any contamination of the downgradient wells not present in the upgradient wells at a site may be assumed to be a product of that site.

Wells are drilled to various depths in the saturated zone below the area to be monitored. A portion of the well casing, the screen, is perforated to allow water to enter the well. Thus, the screen zone refers to the zone of subsurface strata whose water is being sampled by the well. The water rises in the well casing to equilibrate with the hydraulic head of the water surrounding the well's screen zone. By comparing the water levels in adjacent wells screened in the same zone, the hydraulic gradient can be determined and the horizontal direction of groundwater flow estimated.

The vertical direction of groundwater movement between aquifers is controlled by the permeability of the aquitards and the relative difference in hydraulic head of the water on either side of an aquitard. Vertical gradients can be determined by comparing the water levels between adjacent wells screened on either side of an aquitard. If the water levels in deeper 

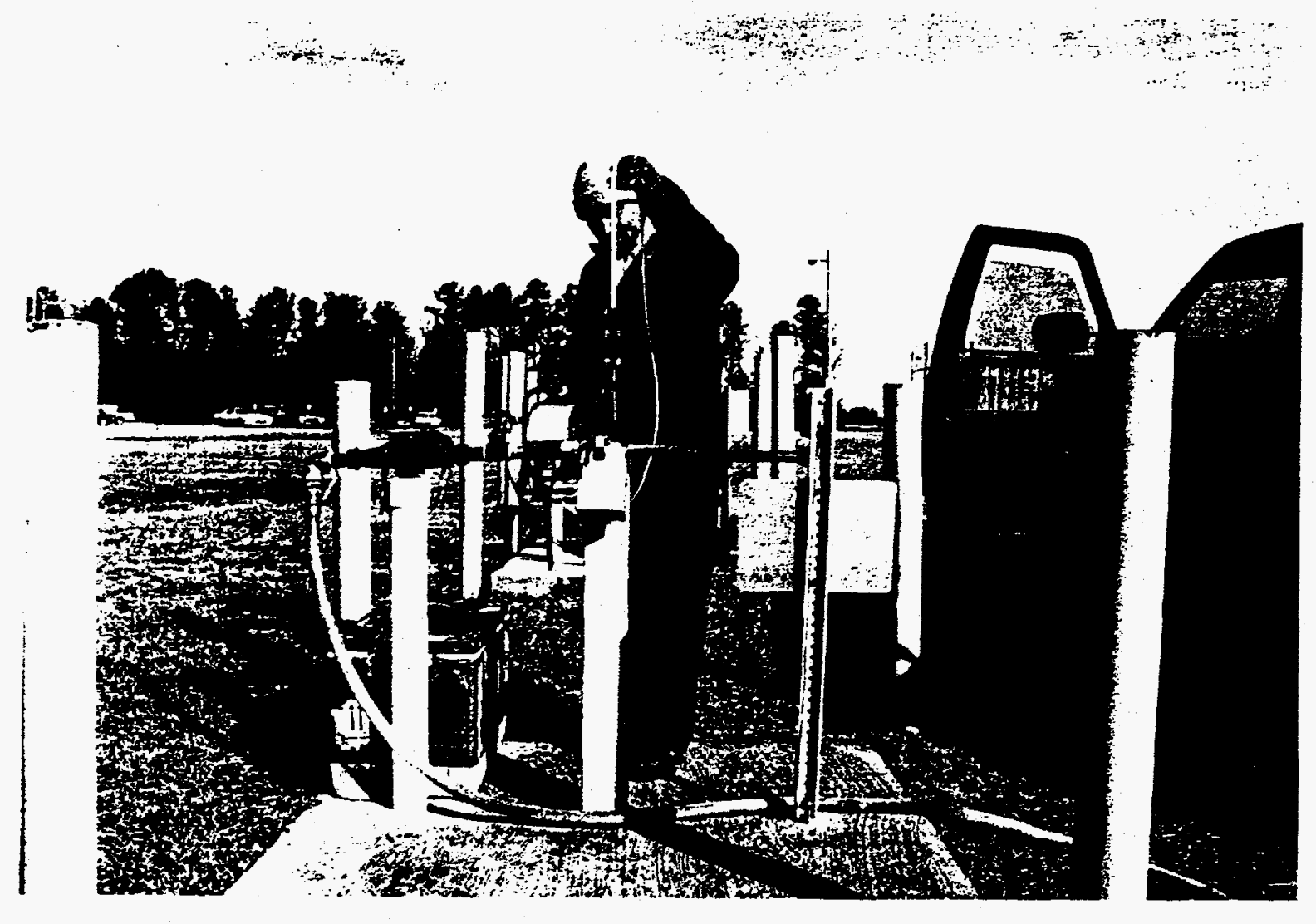

Al Mamatey Photo (96x0258610)

A sampler takes fieid measurements at a well in $\mathrm{H}$-Area as part of the ongoing groundwater monitoring program at SRS. The well is one of approximately 1,600 wells monitored at 94 SRS locations.

wells are higher than those in shallower wells. the vertical component of flow is upward.

\section{Geological and Hydrogeological Setting at SRS}

SRS is located on the Upper Atlantic Coastal Plain, approximately 20 miles southeast of the Fall Line. which separates the Piedmont and Coastal Plain provinces. The site is on the Aiken Plateau, a relatively flat area that slopes southeastward and is dissected by several tributaries of the Savannah River.

Vertical and horizontal groundwater flow directions are determined in part by the permeability and continuity of geologic strata. So that the movement of groundwater and any hazardous constituents it may contain can be monitored effectively, researchers at SRS have undertaken many detailed studies of the strata beneath the site.

SRS is underlain by a 700- to 1,200-foot-thick. seaward-thickening wedge of Coastal Plain sediment composed of unconsolidated sands, clayey sands, sandy clays, clays, and lesser amounts of calcareous sediment. These layers are underlain by dense Paleozoic crystalline igneous and metamorphic rock or younger consolidated sediments of the Triassic Period. The Triassic formations and the older igneous and metamorphic rocks are hydrologically isolated from the overlying Coastal Plain sediments by a regional aquitard. A cross section of the Coastal Plain sediments is presented in figure 10-4, page 164 .

Within the Coastal Plain sediments, the sandy strata generally are permeable and may form aquifers. Strata rich in clays are made less permeable by the presence of minute, pore-filling clay particles. Clayey strata, therefore, are less permeable than sandy strata and tend to be aquitards.

Discussed in this report are three major water-bearing zones in Coastal Plain sediments, divided by regional aquitards, as shown in figure 10-4, page 164. In ascending order, these zones are the Dublin-Midville Aquifer System, the confined Gordon aquifer, and the unconfined Upper Three Runs aquifer in most areas (the latter two comprise the Floridian Aquifer System). Monitoring wells at SRS are used primarily 
to sample water from these zones. In the SRS Environmental Report for 1994, the following nomenclature referred to the water-bearing zones (in ascending order): the Cretaceous zone. the Congaree-Fourmile zone, and the upper saturated zone.

Northwest of Upper Three Runs Creek, a different nomenclature is used for approximately the same zones. In this area, the lowest unit is the Crouch Branch aquifer, the next unit is the Lost Lake aquifer, and the upper unconfined unit is the M-Area aquifer. The Crouch Branch confining unit overlies the Crouch Branch aquifer, and within this unit a "middle sand" unit is monitored near A-Area and M-Area.

The deepest aquifer monitored at SRS occurs in sediments of geologic formations of Cretaceous age. These Cretaceous sediments are largely permeable quartz sands and sandy clays capable of yielding abundant water; they constitute a regionally important aquifer. The Dublin-Midville Aquifer System is separated from the overlying Gordon aquifer by a regional aquitard composed of sandy-clay and clay sediments.

The Gordon aquifer, a locally important source of groundwater, occurs in moderately to well-sorted sand and interbedded sandy-clay sediments capable of yielding several hundred gallons of water per minute. A local aquitard, composed predominantly of clay and identified in SRS literature as "Green Clay," overlies the Gordon aquifer, separating it from the Upper Three Runs aquifer. In the Savannah River Valley between SRS and Georgia, this aquitarcl and the sediments of the underlying Gordon aquifer have been eroded by river channel migration and incision.

Sediments of the Upper Three Runs aquifer are predominantly sandy clay and calcareous and generally yield low amounts of water. Numerous discontinuous clay-rich layers (including the "Tan Clay" of SRS literature) create local aquitards in the upper saturated zone, resulting in locally complex patterns of groundwater flow.

At SRS, the horizontal direction of groundwater movement is governed largely by the depths of incisions of the creeks and streams where water is discharged to the surface. The valleys of the sinaller perennial streams allow discharge from the upper saturated formations. The valleys of major tributaries of the Savannah River drain formations of intermediate depth, and the valley of the Savannah River drains deep formations. Generally, ground water in the deep Dublin-Midville Aquifer System flows toward and discharges into the Savannah River on both the Georgia and South Carolina sides of the river. Groundwater in intermediate-depth lower Eocene-age formations (the Gordon aquifer) flows toward and discharges into Upper Three Runs Creek or the Savannah River, depending on proximity. Groundwater in younger sediments (the Upper Three Runs aquifer) generally flows toward and discharges into the nearest perennial stream, swamp, or river.

Few aquitards are continuous across SRS. Generally, in the northwestern part of the site (near A-Area and $M$-Area; figure 10-4, page 164), aquitards are less continuous, permitting verical flow of groundwater. Where aquitards are more continuous, as they are in the southeastern portion of SRS, groundwater movement is predominantly horizontal. Along the Pen Branch fault (figure 10-4, page 164), aquitards (and transmissive zones) are offset, making the aquitards effectively discontinuous and increasing the likelihood of vertical interchange of water from one transmissive zone to another.

Beneath much of SRS, hydraulic head decreases with depth, so the vertical component of groundwater flow is downward. This is the case in A-Area and M-Area, where discontinuous aquitards and downward-decreasing hydraulic head allow the downward movement of water from the water table to deeper zones. This type of area is called an aquifer recharge zone (figure 10-5, page 165). However, because of the discharge of groundwater to the valleys of Upper Three Runs Creek and the Savannah River, the hydraulic head in sediments in the Gordon aquifer near these surface water features is less than the hydraulic head in the Dublin-Midville Aquifer System. Thus, the vertical hydraulic gradient is upward, from the lower to the upper sediments, in some areas. This upward flow occurs, for example, in the separations and waste management areas (in the center of SRS), where both the aquitard and an upward hydraulic gradient restrict downward flow of groundwater-and any associated hazardous substances-from the Gordon aquifer into the Dublin-Midville Aquifer System.

\section{Uses of Groundwater in the Vicinity of Savannah River Site}

Groundwater is used as a domestic, municipal, and industrial water supply throughout the Upper Coastal Plain. Most municipal and industrial water supplies in Aiken County, South Carolina, are developed from the Cretaceous zone. Domestic water supplies are developed primarily from the Gordon aquifer and the Upper Three Runs aquifer. In Barnwell and Allendale counties of South Carolina, some municipal users are supplied from the Gordon aquifer and overlying units that thicken to the southeast. 
At SRS, most groundwater production is from the Dublin-Midville Aquifer System, with a few lower capacity wells pumping from the Gordon aquifer. Every major operating area at the site has groundwater production wells. Total groundwater production at SRS is from 9 to 12 million gallons per day, which is similar to the volume pumped for industrial and municipal production within 10 miles of the site.

\section{Description of Monitoring Program}

The groundwater monitoring program at SRS gathers information to determine the effect of site operations on groundwater quality. The program's objectives are designed to

- obtain data to determine baseline conditions of groundwater quality

- demonstrate compliance with and implementation of applicable regulations and U.S. Department of Energy (DOE) orders

- provide data to permit the early detection of groundwater contamination

- report detected groundwater contamination

- identify existing and potential groundwater contamination sources and maintain surveillance of these sources

- provide data upon which decisions can be made concerning land disposal practices and the management and protection of groundwater resources

- provide data that support information provided to the public

- maintain a continuous record of the effect of facility operations on groundwater quality

- provide data that will allow predictions of groundwater flow and transport models to be verified

- conduct scientific studies to describe the quantity and quality of groundwater at and near the site and the fate of contaminants in the subsurface

The groundwater monitoring program at SRS is conducted by the Environmental Geochemistry Group (EGG) of the Environmental Monitoring Section/Environmental Protection Department (EPD/EMS) of WSRC. To assist other departments in meeting their responsibilities, EGG provides the services for installing monitoring wells, collecting and analyzing samples, and reporting results.

The Savannah River Site Environmental Monitoring Plan (WSRC-3Q1-2, Section 2000) provides details about the following aspects of the groundwater monitoring program:

- well siting, construction, maintenance, and abandonment

- sample planning

- sample collection and field measurements

- analysis

- data management

- related publications, files, and databases

The next four sections of this chapter present overviews of several of these topics, along with information specific to 1995.

\section{Sample Scheduling and Collection}

EMS schedules groundwater sampling either in response to specific requests from SRS personnel or as part of its ongoing groundwater monitoring program. These groundwater samples provide data for reports required by federal and state regulations and for internal reports and research projects. The groundwater monitoring program schedules wells to be sampled at intervals ranging from quarterly to triennially. Groundwater from new wells added to the program is analyzed for environmental-screening constituents (table 10-1, page 134) for four consecutive quarters. Except for a number of old wells not constructed properly for collecting samples for all analyses, the environmental-screening analyses are conducted once every 3 years only for the wells identified in Savannah River Site Screening Program Wells (ESH-EMS-950409).

Wells identified in ESH-EMS-950409 are sampled annually if their environmental-screening constituent concentrations are above certain limits.

Phenolphthalein alkalinity was added as a field measurement during second quarter 1995. Alkalinity (as $\mathrm{CaCO}_{3}$ ) also is measured in the field during most sampling events.

Personnel outside EMS may request sample collection as often as weekly. In addition to environmental-screening constituents, constituents that may be analyzed by request include suites of herbicides, pesticides, additional metals, volatile organics, and others. Radioactive constituents that may be analyzed by request include gamma emitters, iodine-129, strontium-90, radium-228, uranium isotopes, and other alpha and beta emitters.

Groundwater samples are collected from monitoring wells, generally with either pumps or bailers dedicated to the well to prevent cross-contamination among wells. Occasionally, portable sampling 
ATTACHMENT E

SURFACE WATER 
Table 6-4

TLD Surveillance Results Summary for 1995

\begin{tabular}{lccl}
$\begin{array}{l}\text { Monitoring } \\
\text { Subprogram }\end{array}$ & $\begin{array}{l}\text { Mean Exposure } \\
\text { (mrem per year) }\end{array}$ & $\begin{array}{l}\text { Maximum Exposure } \\
\text { (mrem per year) }\end{array}$ & $\begin{array}{l}\text { Maximum-Exposure } \\
\text { Location }\end{array}$ \\
\hline On site & 98.69 & 275.04 & N-Area \#5 \\
Site perimeter & 73.45 & 106.28 & Perimeter \#49 \\
Air surveillance & 81.72 & 124.75 & BG North \\
Population centers & 81.94 & 100.16 & Girard, GA \\
NRCNogtle & 65.83 & 89.76 & NRC \#5 \\
\hline
\end{tabular}

particular stream locations are documented in the SRS EM Program.

\section{Surveillance Results}

The average gross alpha, gross beta, and tritium concentrations at downstream locations near the creek mouths are presented in table 6-5. A graph showing the average concentration over an 8-year period is presented in figure 6-5. The locations of these stations, well below all points at which radioactivity is introduced into the respective streams, ensure that adequate mixing has taken place and that a representative sample is being analyzed. Concentrations at surveillance station U3R-1A (above process effluents and runoff locations on Upper Three Runs Creek) and at an Edisto River surveillance station in the Aiken State Park above SRS are listed for comparison purposes in table 6-5. The following sections contain discussions of surveillance results from each of the major SRS creeks.

\section{Tims Branch}

A tributary of Upper Three Runs Creek, Tims Branch receives effluents from $M$-Area and SRTC. A surveillance point on Tims Branch, TB-5, is located downstream of all release points and before entry into Upper Three Runs Creek. Tritium was below the lower limit of detection in Tims Branch in 1995, and gross alpha and beta measurements, while above the detection limits, are comparable to levels seen above SRS at the U3R-1A and the Edisto sampling locations.

\section{Upper Three Runs Creek}

Upper Three Runs Creek receives discharges from the Effluent Treatment Facility (ETF), flow from Tims Branch, effluent from the Naval Fuels Facility, and stormwater runoff from F-Area and $\mathrm{H}$-Area.
Tritium, the predominant radionuclide detected in Upper Three Runs Creek, is discharged primarily from the ETF. The average concentration of tritium in 1995 at U3R-4, located on SRS Road A, was (2.21 \pm 1.57)E- $-06 \mu \mathrm{Ci} / \mathrm{mL}$, which was 11 percent of the $2.00 \mathrm{E}-05-\mu \mathrm{Ci} / \mathrm{mL}$ EPA drinking water standard for tritium-down from 18 percent in 1994. Gross alpha concentrations in Upper Three Runs Creek were slightly above those observed at the Edisto River station. The highest concentrations are believed to be caused by naturally occurring radium, thorium, and/or uranium from heavy mineral deposits common 10 waters in these sampling areas.

\section{Four Mile Creek}

Four Mile Creek receives effluents from F-Area, H-Area, and C-Area, as well as from water that has migrated from seepage basins and is outcropping into the stream. Four Mile Creek transported the majority of radioactivity present in SRS streams in 1995, mostly in the form of gross beta-gamma activity and tritium. The gross beta-gamma is made up of strontium- 89,90 (outcropping from retired seepage basins) and cesium-137 (from direct releases and resuspension of activity deposited in the streambed). The amount of tritium transported in Four Mile Creek was approximately 69 percent of the total amount reaching the Savannah River in 1995. Because the highest tritium concentrations are present at surveillance points along Four Mile Creek, and not at the stations monitoring direct releases, most of the tritium transport is due to outcropping activity from retired seepage basins and from the SWDF. This activity is expected to decrease as a result of the closure of the F-Area and H-Area seepage basins in 1988.

\section{Pen Branch}

Pen Branch receives discharges from K-Area and flow from a tributary, Indian Grave Branch. Because 
K-Reactor did not operate in 1995, tritium detected in Pen Branch was due to water entering from Indian Grave Branch, which carries tritium outcropping from the K-Area percolation field and seepage basins. The average tritium concentration at PB-3 was $(6.89$ $\pm 1.33) \mathrm{E}-05 \mu \mathrm{Ci} / \mathrm{mL}$ in 1995 . slightly higher than the level observed in 1994. EMS is planning to begin an investigation in 1996 to determine the cause of this increase in tritium.

\section{Steel Creek}

Steel Creek receives releases from $L$-Area effluents and tritium migration from $P$-Area seepage basins. When P-Area diverts water away from PAR Pond to Steel Creek, the area's discharges are transpored to the stream. All releases enter L-Lake, water from which overflows into Steel Creek and is monitored at SC-4. Gross alpha concentrations at SC-4 were below detection limits in 1995 Gross beta concentrations were slightly above detection limits, at (1.62 \pm $0.78) \mathrm{E}-09 \mu \mathrm{Ci} / \mathrm{mL}$, with tritium being detected at an average concentration of $(6.97 \pm 0.93) \mathrm{E}-06 \mu \mathrm{Ci} / \mathrm{mL}$. Because the highest tritium concentration, (1.14 \pm $0.05) \mathrm{E}-05 \mu \mathrm{Ci} / \mathrm{mL}$, was measured at the surveillance station at SC-2A, and not at the direct-release monitoring stations in L-Area and P-Area, activity being transported in Steel Creek is attributed to outcropping from the P-Area seepage basins.

\section{Lower Three Runs Creek}

Lower Three Runs Creek receives overflow from PAR Pond, a manmade pond that receives discharges from P-Area. Gross beta concentrations in PAR Pond and Lower Three Runs Creek are above detection limits; this is atuributable to low concentrations of cesium-137 from previous releases during P-Area and R-Area operations. Average gross alpha and tritium concentrations are below detection limits.

\section{Savannah River}

Continuous surveillance is performed along the Savannah River at points above and below SRS and below the point at which Plant Vogtle liquid discharges enter the Savannah River. In 1995, five locations along the river served as environmental surveillance points. River sampling locations are shown in figure 6-4.

\section{Description of Surveillance Program}

The Savannah River, which provides SRS its western boundary for a 35-mile stretch, is analyzed to determine what effect the site's effluents have on the

Table $6-5$

Average 1995 Concentration of Radioactivity in SFS and Surveillance Station Waters $(\mu \mathrm{Ci} / \mathrm{mL})$

Locationa

Lower Limits of Detection

Onsite Downstream Locations

Tims Branch (TB-5)

$(1.47 \pm 0.59) E-09$

Upper Three Runs (U3R-4)

$(1.30 \pm 0.56) E-09$

Four Mile Creek (FMC-6)

$(2.81 \pm 3.01) E-10$

Pen Branch (PB-3)

$(1.07 \pm 2.38) E-10$

Steel Creek (SC-4)

$(0.84 \pm 1.95) E-10$

Lower Three Runs (L3R-2)

$(3.25 \pm 3.08) E-10$

Onsite Surveillance Station (for comparison pumposes)

Upper Three Runs (U3R-1A) $\quad(2.12 \pm 0.85) E-09$

Lower Limit of Detection

Offsite Surveillance Station (for comparison purposes)

Edisto River $\quad(7.67 \pm 4.29) E-10$

\section{Gross Beta}

1.55E-09

$(2.39 \pm 0.99) E-09$

$(1.27 \pm 0.59) E-09$

$(1.03 \pm 0.26) E-08$

$(1.25 \pm 0.64) E-09$

$(1.62 \pm 0.78) E-09$

$(1.84 \pm 0.71) E-09$

$(1.59 \pm 0.72) E-09$
Tritium

$1.30 \mathrm{E}-06^{\mathrm{b}}$
$(5.08 \pm 3.45) E-07$

$(9.66 \pm 3.41) E-07$

$(2.21 \pm 1.57) E-06$

$(2.28 \pm 0.33) E-04$

$(6.89 \pm 1.33) E-05$

$(6.97 \pm 0.93) E-06$

$(9.88 \pm 3.47) E-07$

a Site surveillance locations are near mouths of streams.

b Lower limit of detection for tritium by short count

c Lower limit of detection for tritium by long count 


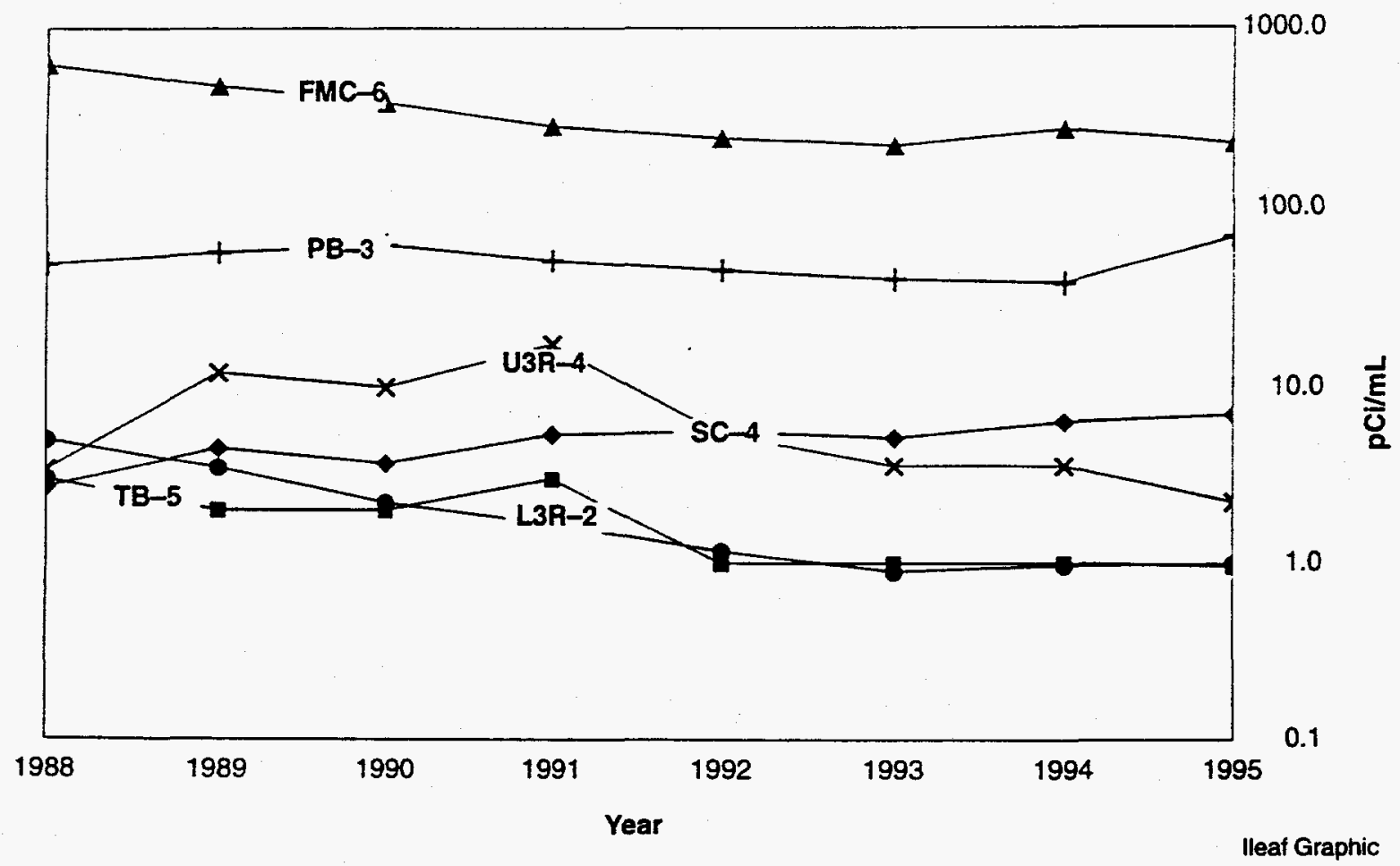

Figure 6-5 Average Tritium Concentration in SRS Streams, 1988-1995

Stream water analysis shows a faily steady decrease in the concentration of tritium in SRS streams.

river water. Gross screening for alpha and beta emitters, along with determinations of specific radionuclides. such as tritium and gamma emitters, is performed on weekly, biweekly, and monthly composites. The collection of strontium- 89,90 samples on the Savannah River was inadvertently omitted in 1995.

\section{Surveillance Results}

\section{Gross Alpha, Gross Beta, and Tritium}

The average concentrations of gross alpha, gross beta, and tritium at river locations are presented in table
$6-6$. The order of the locations begins at $R M-160$, above the site, and ends at RM-120, after all site streams enter the Savannah River. Samplers situated between RM-160 and RM-120 are located at regular intervals along the SRS boundary and where Plant Vogtle discharges feed into the river.

Tritium is the predominant radionuclide detected above background levels in the Savannah River. The highest average concentration in 1995 , $(1.74 \pm 1.00) \mathrm{E}-06 \mu \mathrm{Ci} / \mathrm{mL}$, was measured at RM-150. The average concentration above SRS, measured at $R M-160$, was $(2.09 \pm 1.86) \mathrm{E}-07 \mu \mathrm{Ci}$ $\mathrm{mL}$. The average concentration at $\mathrm{RM}-120$, located

Table 6-6

Average 1995 Concentration of Radioactivity in the Savannah River $(\mu \mathrm{Cu} / \mathrm{mL})$

\begin{tabular}{|c|c|c|c|}
\hline $\begin{array}{l}\text { Location } \\
\text { Lower Limits of Detection }\end{array}$ & $\begin{array}{c}\text { Gross Alpha } \\
6.23 E-10\end{array}$ & $\begin{array}{c}\text { Gross Beta } \\
1.55 \mathrm{E}-09\end{array}$ & $\begin{array}{l}\text { Tritium } \\
4.07 E-07\end{array}$ \\
\hline $\mathrm{RM}-120$ & $(0.82 \pm 2.40) E-10$ & $(1.98 \pm 0.59) E-09$ & $(1.28 \pm 0.45) E-06$ \\
\hline$R M-140$ & $(1.96 \pm 3.44) E-10$ & $(2.33 \pm 0.96) E-09$ & $(1.54 \pm 0.63) E-06$ \\
\hline $\mathrm{RM}-150$ & $(1.42 \pm 3.17) E-10$ & $(1.98 \pm 0.62) E-09$ & $(1.74 \pm 1.00) E-06$ \\
\hline Vogtle discharge & $(1.73 \pm 2.60) E-10$ & $(1.94 \pm 0.74) E-09$ & $(0.79 \pm 1.01) E-06$ \\
\hline $\mathrm{RM}-160$ & $(0.83 \pm 2.71) E-10$ & $(2.19 \pm 1.52) E-09$ & $(2.09 \pm 1.86) E-07$ \\
\hline
\end{tabular}


on U.S. Highway 301 below SRS, was

$(1.28 \pm 0.45) \mathrm{E}-06 \mu \mathrm{Ci} / \mathrm{mL}$. The $\mathrm{RM}-120$

concentration was 6 percent of the $2.00 \mathrm{E}-05-\mu \mathrm{Ci} / \mathrm{mL}$ drinking water standard set by EPA for tritium in drinking water.

\section{Tritium Transport in Streams and River}

Tritium is introduced into SRS streams and the Savannah River via production areas on site. Because of the mobility of tritium in water and the quantity of the radionuclide released during the years of SRS operations, a tritium balance has been performed annually since 1960 . The balance is evaluated among the following alternative methods of calculation:

- tritium releases from effluent release points and calculated seepage basin migration (direct releases)
- tritum transpor in SRS streams and the last sampling point before entry into the Savannah River (stream transport)

- tritium transport in the Savannah River downriver of SRS after subtraction of any measured contribution above the site (river transport)

Figure 6-6 shows graphic and numeric summaries of the last 36 years of direct releases, stream transport, and river transport determined by EMS.

In 1995, tritium transport remained at levels consistent with those of 1994. Stream transport showed a slight increase-probably because of increased migration from site seepage basins.

General agreement between the three calculational methods of annual tritium transport-measurements at the source, stream transport, and river transport-serves to validate SRS sampling schemes and counting results. Differences between the various methods can be attributed to uncertainties arising in the collection and analytical processes, including

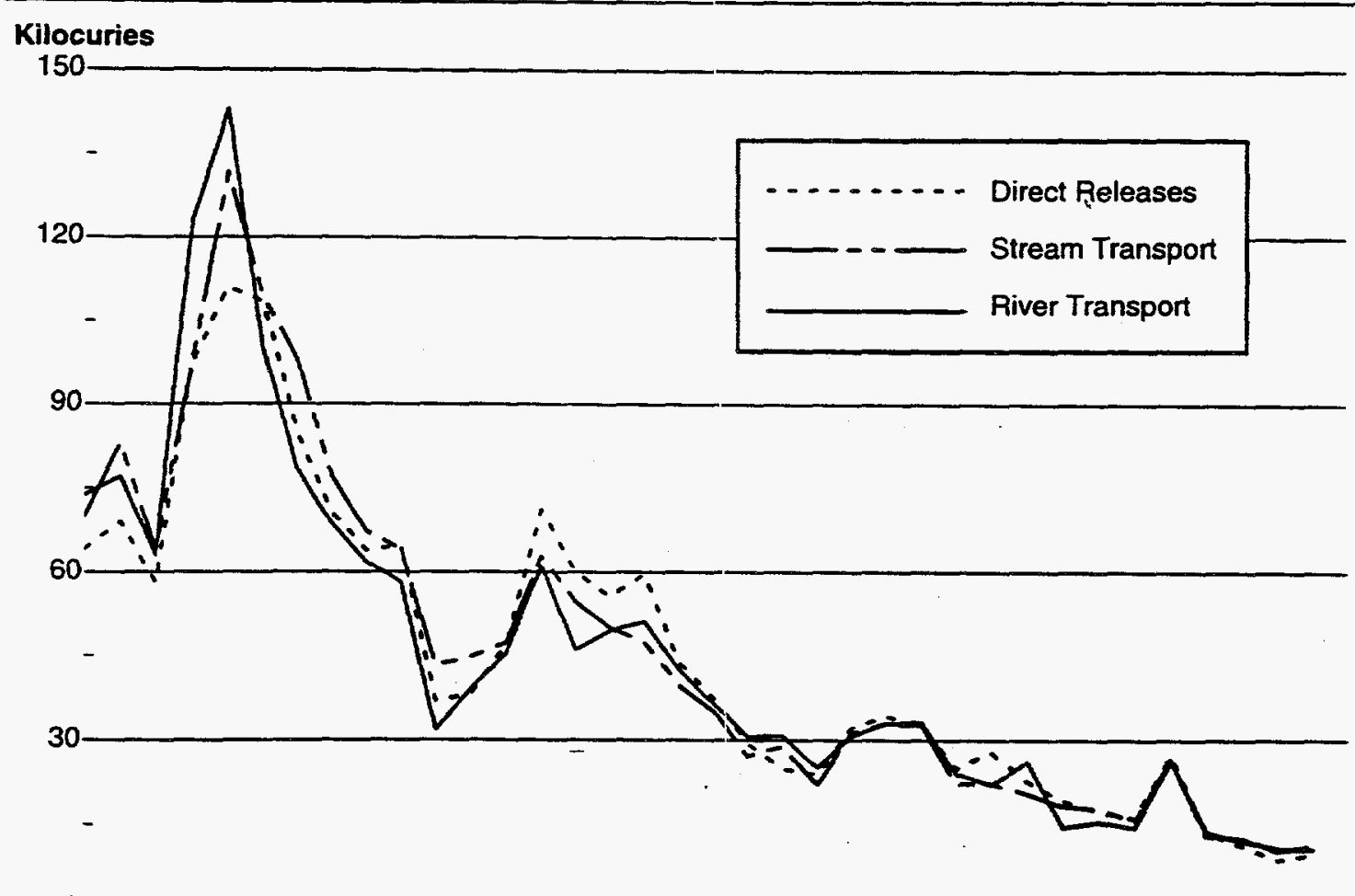

1960196219641966196819701972197419761978198019821984198619881990199219941996

Year

Ileaf Graphic

Figure 6-6 SRS Tritium Transport Summary, 1960-1995

SRS has maintained a tritium balance of direct releases, stream transport, and river transport since 1960 in an effort to account for and trend tritium releases in liquid effluents from the site. The general downward slope over time indicates that tritium transport has decreased as production has slowed and effluent controls have been developed. 


\section{INTERNAL DISTRIBUTION}

\author{
1. J. J. Carbajo \\ 2. B. S. Cowell \\ 3. S. E. Fisher \\ 4. E. C. Fox \\ 5. R. G. Gilliland \\ 6. S. R. Greene \\ 7. S. A. Hodge \\ 8. R. Holdaway \\ 9. S. B. Ludwig \\ 10. G. T. Mays \\ 11. K. L. McElhaney \\ 12. G. E. Michaels \\ 13. R. N. Morris
}

\author{
14. D. L. Moses \\ 15. D. G. O'Connor \\ 16. R. T. Primm III \\ 17. R. R. Rahn \\ 18. J. D. Sease \\ 19. C. C. Southmayd \\ 20. V.S. White \\ 21. C. K. Williams \\ 22. D. L. Williams, Jr. \\ 23. Central Research Library \\ 24-25. ORNL Laboratory Records (OSTI) \\ 26. ORNL Laboratory Records-RC
}

\section{EXTERNAL DISTRIBUTION}

27. H. R. Canter, U.S. Department of Energy, MD-3, 1000 Independence Avenue SW, Washington, DC 20585.

28. J. Eichner, Science Applications International Corp., 20201 Century Blvd., Germantown, MD 20874.

29. K. Gandee, U.S. Department of Energy, MD-4, 1000 Independence Avenue SW, Washington, DC 20585.

30. R. L. Geddes, Westinghouse Savannah River Co., Savannah River Site, Bldg. 704, Room 110, Aiken, SC 29808.

31. C. Groome, Science Applications International Corp., 20201 Century Blvd., Germantown, MD 20874.

32. D. Hirrlinger, Science Applications International Corp., 20201 Century Blvd., Germantown, MD 20874.

33. J. V. Johnson, , U.S. Department of Energy, MD-4, 1000 Independence Avenue SW, Washington, DC 20585.

34. D. J. Nulton, U.S. Department of Energy, MD-4, 1000 Independence Avenue SW, Forrestal Bldg., Room 6G-050, Washington, DC 20585.

35. D. Peko, , U.S. Department of Energy, MD-3, 1000 Independence Avenue SW, Washington, DC 20585.

36. A. P. Poon, Westinghouse Savannah River Co., Savannah River Site, Bldg. 704, Room 118, Aiken, SC 29808

37. P. T. Rhoads, , U.S. Department of Energy, MD-3, 1000 Independence Avenue SW, Washington, DC 20585.

38. D. L. Spiker, Westinghouse Savannah River Co., Savannah River Site, Bldg. 704, Room 118, Aiken, SC 29808.

39. G. B. Stevenson, U.S. Department of Energy, MD-4, 1000 Independence Avenue SW, Washington, DC 20585.

40. J. H. Thompson, , U.S. Department of Energy, MD-4, 1000 Independence Avenue SW, Washington, DC 20585.

41. T. H. Wynn, U.S. Department of Energy, ORO, P.O. Box 2001, Oak Ridge, TN 37831-8283. 


\section{DOE PUBLIC READING ROOMS}

42. Albuquerque Operations Office, TV1 Community College Library, Montoya Campus, 4700 Morris, NE, Albuquerque, NM 8711.

43. Amarillo Area Office, U.S. Department of Energy, Amarillo College, Lynn Library/Learning Center, 2201 South Washington, P.O. Box 447, Amarillo, TX 79178.

44. U.S. DOE Reading Room, Carson County Library, 401 Main Street, P.O. Box 339, Panhandle, TX 79068.

45. Chicago Operations Office, Office of the Manager/Communications, U.S. Department of Energy, 9800 South Cass Avenue, Argonne, IL 60439.

46. Idaho National Engineering and Environmental Laboratory, Idaho Public Reading Room, 1776 Science Center Drive, Idaho Falls, ID 83402.

47. Los Alamos National Laboratory, U.S. Department of Energy, c/o Los Alamos Community Reading Room, 1350 Central, Suite 101, Los Alamos, NM 37544.

48. Nevada Operations Office, U.S. Department of Energy, Public Reading Room, 2621 Losse Road, North Las Vegas, NV 89030.

49. Oak Ridge Operations Office, U.S. Department of Energy, Public Reading Room, 200 Administration Road, Room G-217, Oak Ridge, TN 37831-8501.

50. Richland Operations Office, DOE Public Reading Room, 100 Sprout Road, Room 130 West, P.O. Box 999, M/S H2-53, Richland, WA 99352.

51. Rocky Flats Office, Front Range Community College Library, 3645 West 112th Avenue, Westminster, CO 80030 .

52. Sandia National Laboratory/CA, Livermore Public Library, 1000 S. Livermore Avenue, Livermore, CA 94550 .

53. Savannah River Operations Office, Gregg-Graniteville Library, University of South Carolina-Aiken, 171 University Parkway, Aiken, SC 29801.

54. U.S. Department of Energy, Freedom of Information/Privacy Act Public Reading Room, Forrestal Building, Room 1E-190, 1000 Independence Avenue SW, Washington, DC 20585. 